\title{
Quantity and Chemical Quality of Recharge, and Updated Water Budgets, for the Basin-Fill Aquifer in Eagle Valley, Western Nevada
}

Water-Resources Investigations Report 99-4289

Prepared in cooperation with the CARSON CITY UTILITIES DEPARTMENT and WASHOE TRIBE OF NEVADA AND CALIFORNIA 


\section{Quantity and Chemical Quality of Recharge, and Updated Water Budgets, for the Basin-Fill Aquifer in Eagle Valley, Western Nevada}

By Douglas K. Maurer and Carl E. Thodal

U.S. GEOLOGICAL SURVEY

Water-Resources Investigations Report 99-4289

Prepared in cooperation with the

CARSON CITY UTILITIES DEPARTMENT and

WASHOE TRIBE OF NEVADA AND CALIFORNIA 


\title{
U.S. DEPARTMENT OF THE INTERIOR BRUCE BABBITT, Secretary
}

\author{
U.S. GEOLOGICAL SURVEY \\ CHARLES G. GROAT, Director
}

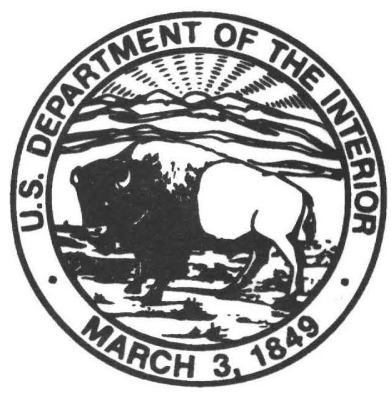

Any use of trade names in this publication is for descriptive purposes only and does not constitute endorsement by the U.S. Government

For additional information contact:

District Chief

U.S. Geological Survey

333 West Nye Lane, Room 203

Carson City, NV 89706-0866

email: GS-W-NVpublic-info @ usgs.gov

http://nevada.usgs.gov
Copies of this report can be purchased from:

U.S. Geological Survey Information Services Building 810

Box 25286, Federal Center Denver, CO 80225-0286 


\section{CONTENTS}

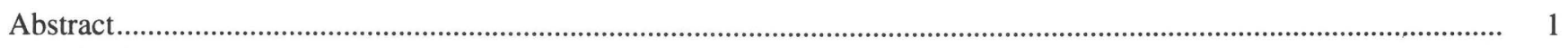

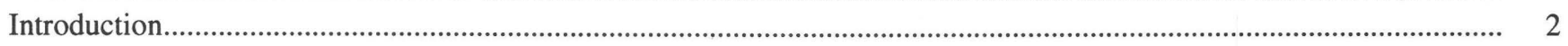

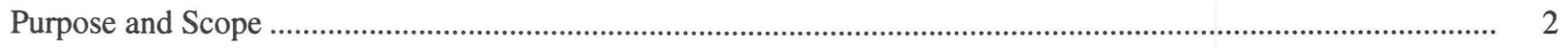

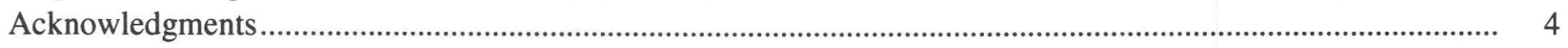

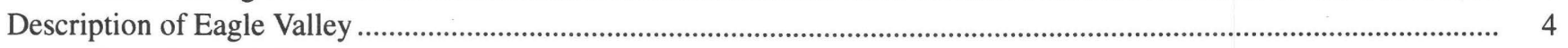

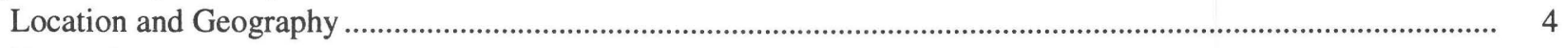

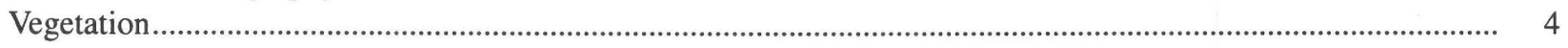

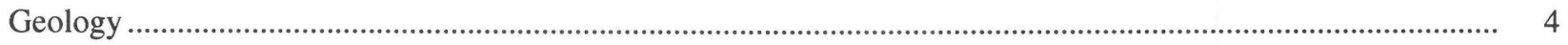

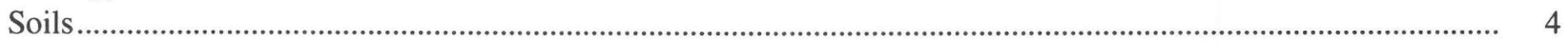

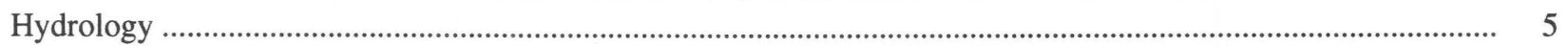

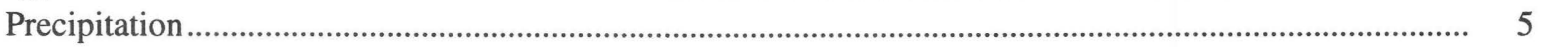

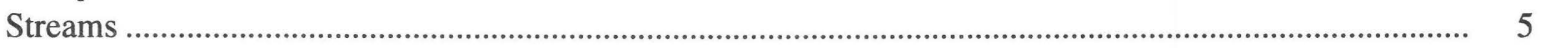

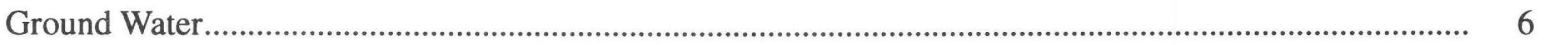

Occurrence, Movement, and Water-Level Changes........................................................................ 6

Previous Estimates of Ground-Water Recharge .......................................................................... 7

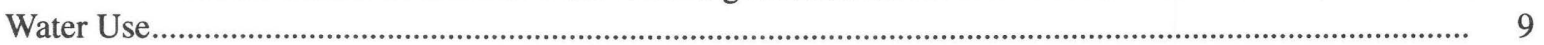

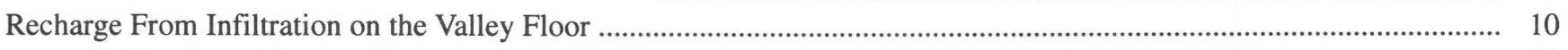

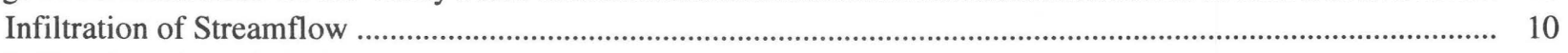

Infiltration of Precipitation and Water Applied for Irrigation ........................................................................ 19

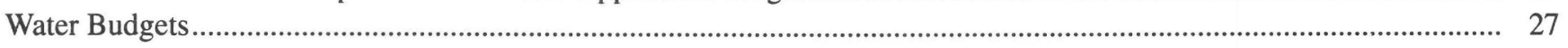

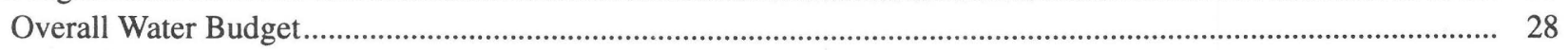

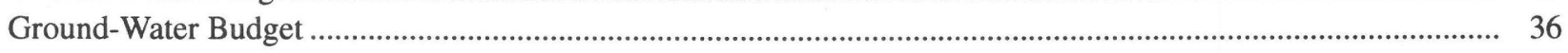

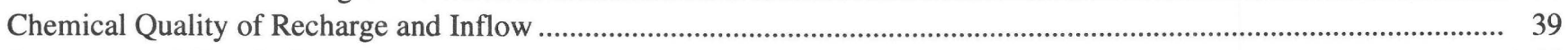

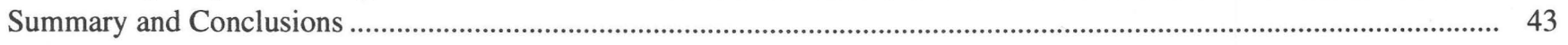

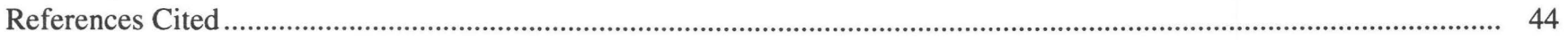

\section{FIGURES}

1. Map showing geographic features, watersheds tributary to valley floor, and location of selected wells,

Eagle Valley, Nevada

2-3. Graphs showing:

2. Annual precipitation in Carson City, Nevada, 1960-98, and average annual precipitation, 1961-90 ................ 6

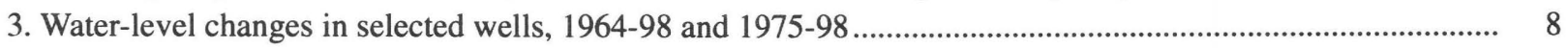

4. Map showing location of streamflow measurement sites, thermocouple sites, and water-quality sampling sites ...... 11

5-6. Graphs showing relation between streamflow:

5. Of Clear Creek at gaging station and outflow from Eagle Valley Hydrographic Area ..................................... 13

6. Remaining after municipal diversions and streamflow loss from Kings Canyon and Ash Canyon Creeks ....... 17

7. Map showing distribution of land use on floor of Eagle Valley, 1997, including areas having saline soils, and location of soil-chloride profile sites

8-10. Graphs showing:

8. Distribution of soil chloride at sites in open areas with non-saline soils and sites in saline soils and irrigated areas

9. Changes in water levels at wells near the mouths of selected watersheds tributary to Eagle Valley, 1994-98... 31

10. Relation between streamflow of Eagle Valley creek near Carson City and total streamflow of unnamed creeks north of Eagle Valley creek.

11. Map showing surficial geology, location of hydrogeologic section and wells used to determine hydraulic gradient, and hydraulic gradient, and hydrogeologic section showing water table in basin-fill sediments and bedrock near southeastern boundary of Eagle Valley Hydrographic Area 


\section{TABLES}

1. Summary of streamflow measurements and gains to and losses from Clear Creek, Eagle Valley, Nevada, 1996-98

2. Summary of estimated recharge from infiltration of streamflow on floor of Eagle Valley, 1995-98 and average conditions

3. Summary of streamflow measurements, municipal diversions, and streamflow losses from Kings and Ash Canyon Creeks, Eagle Valley, Nevada, 1996-98

4. Areas of land use on floor of Eagle Valley, 1997, and areas of non-saline and saline soils within open, residential, and impervious areas

5. Chloride concentration of pore water, precipitation, and irrigation water; rates of precipitation and irrigation; and estimates of recharge rates from selected soil-chloride profiles

6. Summary of estimated recharge from infiltration of precipitation and water applied for irrigation on floor of Eagle Valley

7. Overall water budget for floor of Eagle Valley, 1995-98 and average conditions

8. Estimates of evapotranspiration from different types of land use on floor of Eagle Valley

9. Ground-water budget for floor of Eagle Valley, 1995-98 and average conditions ................................................ 37

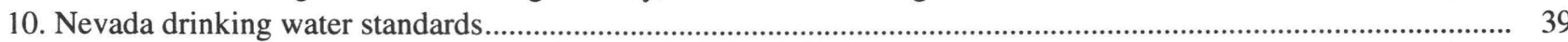

11-13. Summary of water-quality data for:

11. Snow cores from Sierra Nevada and precipitation samples from Smith Valley, Nevada

12. Selected surface- and ground-water sites, 1994-97

13. Municipal water supply, 1994-97, treated effluent from wastewater reclamation plant, 1993-98, and Brunswick reservoir, 1987-91

\section{CONVERSION FACTORS AND VERTICAL DATUM}

\begin{tabular}{rll}
\hline Multiply & By & To obtain \\
\hline acres & 4,047 & square meter \\
cubic meter per year \\
acre-foot per year (acre-ft/yr) & 1,233 & cubic meter per second \\
cubic foot per second $\left(\mathrm{ft}^{3} / \mathrm{s}\right)$ & 0.02832 & meter \\
foot $(\mathrm{ft})$ & 0.3048 & meter per day \\
foot per day $(\mathrm{ft} / \mathrm{d})$ & 0.3048 & meter per meter \\
foot per foot $(\mathrm{ft} / \mathrm{ft})$ & 1.0 & meter per year \\
foot per year $(\mathrm{ft} / \mathrm{yr})$ & 0.3048 & millimeter \\
inch $(\mathrm{in})$ & 25.4 & meter per hour \\
inch per hour $(\mathrm{in} / \mathrm{hr})$ & 0.0254 & millimeter per year \\
inch per year $(\mathrm{in} / \mathrm{yr})$ & 25.4 & square meter \\
square foot $\left(\mathrm{ft}^{2}\right)$ & 0.09290 & kilometer \\
mile $(\mathrm{mi})$ & 1.609 & square kilometer \\
\hline square mile $\left(\mathrm{mi}{ }^{2}\right)$ & 2.590 & \\
\hline
\end{tabular}

Temperature: Degrees Celsius $\left({ }^{\circ} \mathrm{C}\right)$ can be converted to degrees Fahrenheit $\left({ }^{\circ} \mathrm{F}\right)$ by using the formula ${ }^{\circ} \mathrm{F}=\left[1.8\left({ }^{\circ} \mathrm{C}\right)\right]+32$.

Sea level: In this report, "sea level" refers to the National Geodetic Vertical Datum of 1929 (NGVD of 1929, formerly called "Sea-Level Datum of 1929"), which is derived from a general adjustment of the first-order leveling networks of the United States and Canada.

Water-quality units used in this report:

$\mathrm{mg} / \mathrm{L}$

$\mathrm{pCi} / \mathrm{L}$

milligrams per liter

picocuries per liter

$\mu \mathrm{g} / \mathrm{L}$

micrograms per liter

$\mu \mathrm{S} / \mathrm{cm}$

microsiemens per centimeter at 25 degrees Celsius 


\title{
Quantity and Chemical Quality of Recharge, and Updated Water Budgets, for the Basin-Fill Aquifer in Eagle Valley, Western Nevada
}

\author{
by Douglas K. Maurer and Carl E. Thodal
}

\section{ABSTRACT}

In 1994, the U.S. Geological Survey began a series of studies designed to estimate water resources of Eagle Valley as part of a cooperative program with Carson City Utilities Department and the Washoe Tribe of Nevada and California. Initial work focused on estimating the quantity of water entering the valley floor from the surrounding mountains. Since 1996, studies have focused on estimating ground-water recharge from infiltration on the floor of Eagle Valley and on developing an updated overall water budget and ground-water budget. Estimates were made for 199598, when precipitation was 140 percent of normal, and for average conditions.

In the overall water budget, total estimated inflow to the floor of Eagle Valley was 40,000 acre-ft/yr during 1995-98, and 31,000 acre-ft/yr for average conditions. Average inflow includes 12,000 acre-ft/yr of precipitation and 4,900 acre-ft/yr imported from outside the hydrographic area. Streamflow and subsurface inflow from the mountains average about 14,000 acre$\mathrm{ft} / \mathrm{yr}$ and are long-term sources not affected by changes in land use on the valley floor. However, streamflow is highly variable from year to year, increasing from an average of $9,900 \mathrm{acre}-\mathrm{ft} / \mathrm{yr}$ to $14,000 \mathrm{acre}-\mathrm{ft} / \mathrm{yr}$ in wet years, or decreasing to $4,400 \mathrm{acre}-\mathrm{ft} / \mathrm{yr}$ in dry years. Subsurface inflow from the mountains varies much less, by only about 20 percent from dry years to wet years, averaging 3,800 acre-ft/yr. Estimates of outflow totalled 19,000 acre-ft/yr during 1995-98 and 15,000 acre-ft/yr for average conditions. Average outflow includes 9,600 acre-ft/yr of streamflow and exported treated effluent and 5,100 acre-ft/yr of subsurface outflow to Dayton and Carson Valley Hydrographic Areas.

In the ground-water budget, the total estimated recharge and inflow ranged from 10,000 to 12,000 acre-ft/yr during 1995-98 and ranges from 8,000 to $10,000 \mathrm{acre}-\mathrm{ft} / \mathrm{yr}$ for average conditions, varying much less from wet to dry conditions than inflow in the overall water budget. Average recharge and inflow includes $3,800 \mathrm{acre}-\mathrm{ft} / \mathrm{yr}$ of subsurface inflow from the mountains, 2,600 acre-ft/yr from infiltration of streamflow, 1,400 to 2,900 acre-ft/yr from irrigation of lawns, 30-90 acre-ft/yr from infiltration of precipitation on open land with non-saline soils, and $260 \mathrm{acre}-\mathrm{ft} / \mathrm{yr}$ from septic tanks. Ground-water discharge and outflow estimated during $1995-98$ is probably similar to average conditions and totals 11,000 acre-ft/yr, including 5,100 acre-ft/yr of subsurface outflow, 4,300 acre-ft/yr of pumpage, 370 acre-ft/yr of base streamflow, and 880 acre-ft/yr of evapotranspiration.

Independent estimates of evapotranspiration and increased ground-water storage during 1995-98 show that estimates of water-budget components are reasonable and probably within 20 percent of their actual values. However, the volumes of water-budget components will change as a result of variations in climate and changes in land and water use. Changes in land use that decrease the natural ground-water discharge by evapotranspiration and increase recharge from irrigation of lawns could cause the water table to rise to near land surface in the lower parts of Eagle Valley.

Water quality of streamflow and subsurface inflow from the mountains, precipitation, and water used for irrigation from municipal supply are largely within Nevada drinking-water standards. However, subsurface inflow beneath the west side of Eagle Valley commonly exceeds maximum standards for radon- 222 . Treated effluent and septic tanks are the most likely sources of recharge to cause ground-water contamination. Samples of treated effluent from 1987 to 1997 have concentrations of nitrate, arsenic, cadmium, and lead equal to, or greater than, maximum drinking water standards; and concentrations of dissolved solids, iron, and manganese equal to, or greater than, secondary maximum standards. 


\section{INTRODUCTION}

Continued growth of Carson City, the capital of Nevada, is increasing the demand for municipal water supply. Much of the water supply for Carson City is from ground water in basin-fill aquifers underlying the floor of Eagle Valley. State-permitted pumping of ground water in Eagle Valley is about 8,900 acre- $\mathrm{ft} / \mathrm{yr}$, of which about 6,700 acre- $\mathrm{ft} / \mathrm{yr}$ is allocated to the Carson City municipal supply (Matt Dillon, Nevada Division of Water Resources, written commun., 1999). The basin-fill aquifers in Eagle Valley (fig. 1) can be recharged by subsurface inflow from the adjacent mountains, by infiltration of streamflow and precipitation on the valley floor, and by infiltration of water applied for irrigation of fields, lawns, and golf courses.

Recharge to the Eagle Valley Hydrographic Area ${ }^{1}$ was previously estimated by Worts and Malmberg (1966, p. 15), and by Arteaga and Durbin (1979, p. 14). In 1994, the U.S. Geological Survey, in cooperation with Carson City Utilities Department, began studies to refine the earlier estimates. The initial phase of study developed methods to estimate subsurface inflow to the floor of Eagle Valley from three watersheds in the mountains on the western side of Eagle Valley-Kings Canyon, Ash Canyon, and Vicee Canyons (fig. 1). Measurements of the physical properties controlling ground-water flow toward the valley were made in test holes and wells installed along hydrogeologic cross sections near the mouths of the watersheds. These measurements, and the concentration of dissolved chloride in precipitation, ground water, and streamflow, were used to estimate subsurface inflow from the watersheds (Maurer and others, 1996).

A second phase of study began in 1996 with the U.S. Geological Survey working in cooperation with Carson City Utilities Department and the Washoe Tribe of Nevada and California. Similar measurements were made at five other watersheds, informally named Clear Creek, C-Hill, northwest Kings Canyon, Goni, and Centennial Park; and estimates were made

\footnotetext{
${ }^{1}$ Formal hydrographic areas in Nevada were delineated systematically by the U.S. Geological Survey and Nevada Division of Water Resources in the late 1960's (Cardinalli and others, 1968; Rush, 1968) for scientific and administrative purposes. The official hydrographic-area names, numbers, and geographic boundaries continue to be used in Geological Survey scientific reports and Division of Water Resources administrative activities.
}

of subsurface inflow and water yield (subsurface inflow plus streamflow) from all watersheds tributary to the valley floor (fig. 1; Maurer and Berger, 1997). This information provided a refined estimate of water yield from the mountains surrounding Eagle Valley.

Also during the second phase of study, measurements began for estimation of ground-water recharge on the valley floor from infiltration of streamflow, precipitation, and water applied for irrigation. Estimates of recharge on the valley floor, combined with the estimates of water yield from the surrounding mountains, provide refined estimates of all sources of recharge to the basin-fill aquifer beneath the valley floor. Measurements and estimates of outflow from the valley, combined with estimates of recharge, allow development of an updated overall water budget and ground-water budget for the floor of Eagle Valley.

\section{Purpose and Scope}

The principal purpose of this report is to present estimates of recharge on the floor of Eagle Valley from infiltration of streamflow, precipitation, and water applied for irrigation. These estimates are combined with estimates of water yield from watersheds tributary to the floor of Eagle Valley and estimates of outflow from the valley to obtain an updated overall water budget and ground-water budget that can be used by water managers. Estimates were made for 1995-98, a period when precipitation was 140 percent of normal, and for average conditions.

Recharge from infiltration of streamflow was estimated from measurements of streamflow at 17 sites along Clear, Kings Canyon, and Ash Canyon Creeks, and from measurements at 4 sites of the attenuation of diurnal temperature variations in streamflow and with depth beneath the streambeds. Recharge from infiltration of precipitation and water applied for irrigation was estimated from the concentration of chloride in soils above the water table at 16 sites. Recharge rates at the 16 sites were applied to areas of similar land use to obtain estimates of recharge over the entire valley floor. Data were collected from September 1995 to October 1998. Recharge from septic tanks was estimated from the approximate number of existing tanks multiplied by an estimate of daily use. Ground-water discharge was estimated from available data on ground-water pumpage and reported rates of evapotranspiration applied to the area of open land having saline soils. 


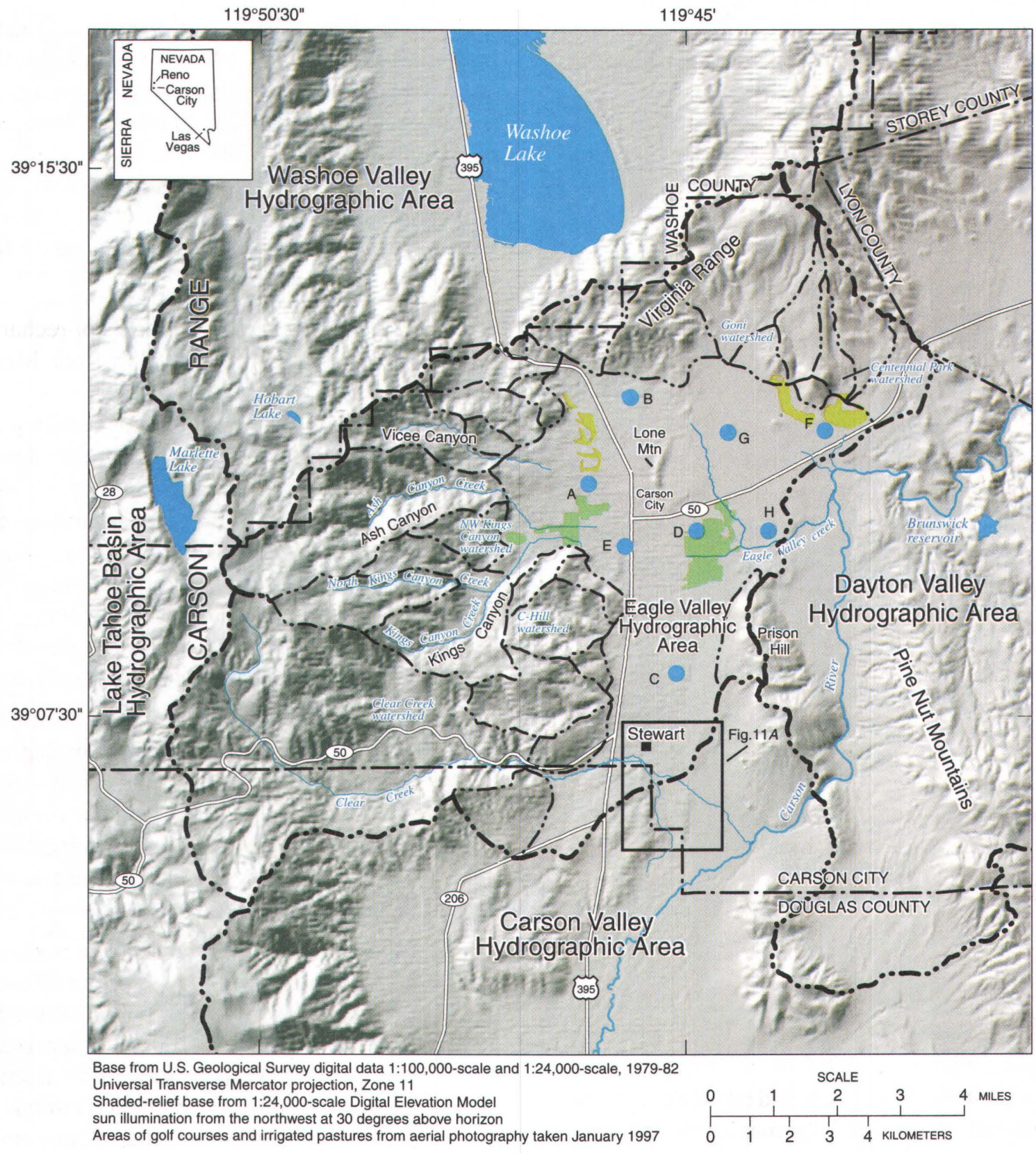

EXPLANATION

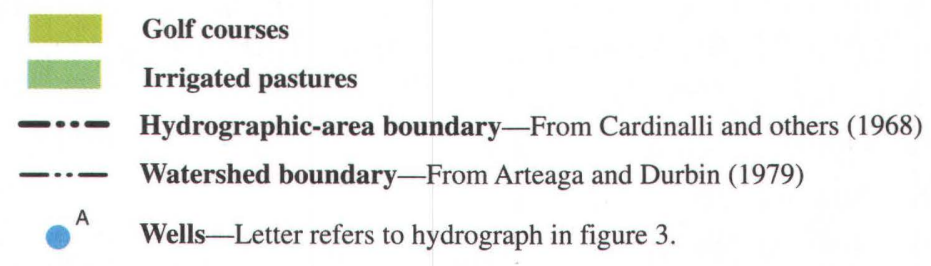

Figure 1. Geographic features, watersheds tributary to valley floor, and location of selected wells, Eagle Valley, Nevada. Area of golf courses and irrigated pastures from aerial photography taken January 1997. 
Water-quality analyses of precipitation, surfaceand ground-water samples taken from November 1994 to September 1997, municipal supply water, and treated effluent are described in terms of drinkingwater standards to allow evaluation of the potential for ground-water contamination.

\section{Acknowledgments}

The authors thank Thomas Hoffert, Kelvin Ikehara, Kyle Menath, Cyril Ouilette, Ken Shannon, Leanna Stevens, and Dorothy Timian-Palmer of Carson City Utilities Department and Scott Fahrenbruch of Carson City Parks and Recreation Department for supplying data, aerial photography, and access to City property for installation of instrumentation; Larry Hale of Nevada Buildings and Grounds for supplying information on diversions from Clear Creek; and the Washoe Tribe of Nevada and California, Mickey Anderson, Steve Hartman, Tim Morsani, Donald Schultz, John Serpa, and Alan Welch for access to their private property for installation of instrumentation and data collection.

\section{DESCRIPTION OF EAGLE VALLEY}

\section{Location and Geography}

Eagle Valley lies along the eastern slope of the Sierra Nevada with a total drainage area of about 70 $\mathrm{mi}^{2}$, or 45,400 acres (Worts and Malmberg, 1966, p. 2 and 15). The valley is bounded on the west by the Carson Range of the Sierra Nevada, on the north by the Virginia Range, on the east by low-lying Prison Hill and the flood plain of the Carson River, and on the south by Carson Valley (fig. 1). The floor of Eagle Valley, an area of about $20 \mathrm{mi}^{2}$, or 13,600 acres (Maurer and Berger, 1997, p. 33), is about $4,700 \mathrm{ft}$ above sea level. The top of Prison Hill is about $5,700 \mathrm{ft}$ above sea level, the top of the Virginia Range is about $8,000 \mathrm{ft}$, and the top of the Carson Range is higher than 9,200 ft. The Eagle Valley Hydrographic Area is largely in Carson City, Nev. Carson City represents combined county and municipal governments and is sometimes referred to as a county as well as the capital of Nevada.

\section{Vegetation}

On the floor of Eagle Valley, much of the natural vegetation of sagebrush, rabbitbrush, bitterbrush, and grassy meadows has been replaced by commercial buildings, houses, streets, and lawns. In 1965, Worts and Malmberg (1966, p. 24) estimated that 700 acres of pasture were irrigated with streamflow from Ash and Kings Canyons. In 1997, pastures covered about 650 acres and about 50 acres had been replaced by development.

\section{Geology}

The mountains surrounding Eagle Valley consist of consolidated rocks that have been uplifted by faulting. The valley floor has been downdropped relative to the mountains, forming a basin that is partly filled with sediments eroded from the surrounding mountains. In this report, the consolidated rocks exposed in the mountains and buried beneath the sediments in the valley are collectively called bedrock; the sediments in the valley are collectively called basin-fill sediments.

Granitic and metamorphic rocks form the bulk of the bedrock outcropping west and north of Eagle Valley and at Prison Hill, and probably underlie much of the valley floor (Moore, 1969, p. 6). Volcanic rocks overlie granitic and metamorphic rocks in the Virginia Range and consist of rhyolite, andesite, and basalt flows, flow breccias, and tuffs (Moore, 1969, p. 11-14).

Basin-fill sediments that overlie bedrock are generally coarse grained near the base of the mountains and finer grained near the center of the valley. These sediments form the principal ground-water reservoir for municipal supply and form the basin-fill aquifer. They are estimated to be about $1,200 \mathrm{ft}$ thick $1.5 \mathrm{mi}$ west of Lone Mountain, about 400 to $800 \mathrm{ft}$ thick beneath the northeastern and southern parts of the valley, and about 2,000 ft thick about 1 mi northwest of Prison Hill (Arteaga, 1986, p. 25).

\section{Soils}

The soils covering Eagle Valley have been described in detail by Candland (1979, p. 57). Soils with slow infiltration rates are found near the lowest parts of the valley and are described as being salinealkali affected by Candland (1979, p. 31 and 42). 


\section{Hydrology}

\section{Precipitation}

The floor of Eagle Valley lies in the rain shadow of the Sierra Nevada. The average annual precipitation on the valley floor was 10.87 in. for 1961-90 at the National Weather Service station near Stewart (Owenby and Ezell, 1992, p. 15). This value agrees well with a map produced by Arteaga and Durbin $(1979$, p. 16), which shows that average precipitation on the valley floor is somewhat less than $10 \mathrm{in} / \mathrm{yr}$ over the northern part and somewhat greater than $10 \mathrm{in} / \mathrm{yr}$ over the south-central part. The map also estimates average annual precipitation of more than $38 \mathrm{in}$. along the crest of the Carson Range, and as much as 16 in. near the crest of the Virginia Range. Most precipitation falls as rain or snow during November through April. Snow in the Carson Range accumulates to several feet during most winters and melts in early spring to early summer.

Using the map by Arteaga and Durbin (1979, p. 16), the total average volume of precipitation that falls within the Eagle Valley Hydrographic Area is about 67,000 acre-ft/yr (Maurer and Berger, 1997, p. 33). Arteaga and Durbin (1979) did not report the time frame for data used to develop their precipitation map; however, data prior to about 1978 were assumed to have been used. The volume of $67,000 \mathrm{acre}-\mathrm{ft} / \mathrm{yr}$ is greater than a previous estimate for Eagle Valley of 58,000 acre-ft/yr by Worts and Malmberg (1966, p. 15), which was based on a map of average annual precipitation for Nevada developed by George Hardman of the Nevada Agricultural Experiment Station in 1936 (Eakin and others, 1951, p. 26). Using more recent precipitation data, the Oregon Climate Service has developed a map of average annual precipitation for 1960-91 for Nevada (G.H. Taylor, Oregon Climate Service, Oregon State University, written commun., May 21, 1997). Applying this map to the eight watersheds instrumented in previous studies by Maurer and others (1996) and Maurer and Berger (1997), a volume of 43,600 acre- $\mathrm{ft} / \mathrm{yr}$ is obtained (David L. Berger, U.S. Geological Survey, written commun., 1998). This volume is about 4 percent less than the volume of 45,600 acre-ft/yr for the eight watersheds reported by Maurer and Berger (1997, p. 32) using the map developed by Arteaga and Durbin (1979, p. 16). The map developed by Arteaga and Durbin (1979) is used in this report as it provides a more detailed distribution of precipitation and appears to provide reasonable estimates of precipitation for 1960-91, a period representative of conditions during the present study. Applying the information from this map, Maurer and Berger (1997, p. 33) calculated an average precipitation on the valley floor of $11,500 \mathrm{acre}-\mathrm{ft} / \mathrm{yr}$.

Major variations in annual precipitation since the 1960 's include above-normal precipitation in the early 1960 's and early-1980's, an extended drought from about 1987 to 1994 , and generally above-normal precipitation in the late 1990's (fig. 2). In January 1997, intense rain on an existing snowpack created historical flooding in much of western Nevada, including Eagle Valley.

\section{Streams}

Streams in the Clear Creek watershed and in Kings, North Kings, and Ash Canyons drain the eastern flank of the Carson Range and are perennial, flowing onto the floor of Eagle Valley even during drought years and across the valley during springs of normal and wet years. Average annual flow of the streams is about 4,000 acre-ft/yr from Clear Creek, 2,000 acre$\mathrm{ft} / \mathrm{yr}$ from Kings and North Kings Canyon Creeks, and 2,600 acre-ft/yr from Ash Canyon Creek (Preissler and others, 1999). The water is used in the valley for irrigation of pastures and municipal water supply. Other streams entering Eagle Valley are ephemeral, flowing onto the valley floor only during spring snow-melt or intense storms.

Flow of Kings Canyon, North Kings Canyon, and Ash Canyon Creeks (fig. 1) that remains after irrigation and municipal diversions is routed into subsurface culverts beneath the urban part of Carson City. The streamflow emerges into open ditches about 1 mi east of U.S. Highway 395, joins Eagle Valley creek (informal name), exits Eagle Valley north of Prison Hill, and discharges into the Carson River. Small unnamed creeks drain the northeastern part of Eagle Valley and discharge north of Eagle Valley creek into the Carson River. Clear Creek flows eastward across the southernmost end of Eagle Valley, with diversions for irrigation of lawns at Stewart and pastures south of Stewart in the Carson Valley Hydrographic Area. Flow from Clear Creek enters Carson Valley and discharges into the Carson River. 


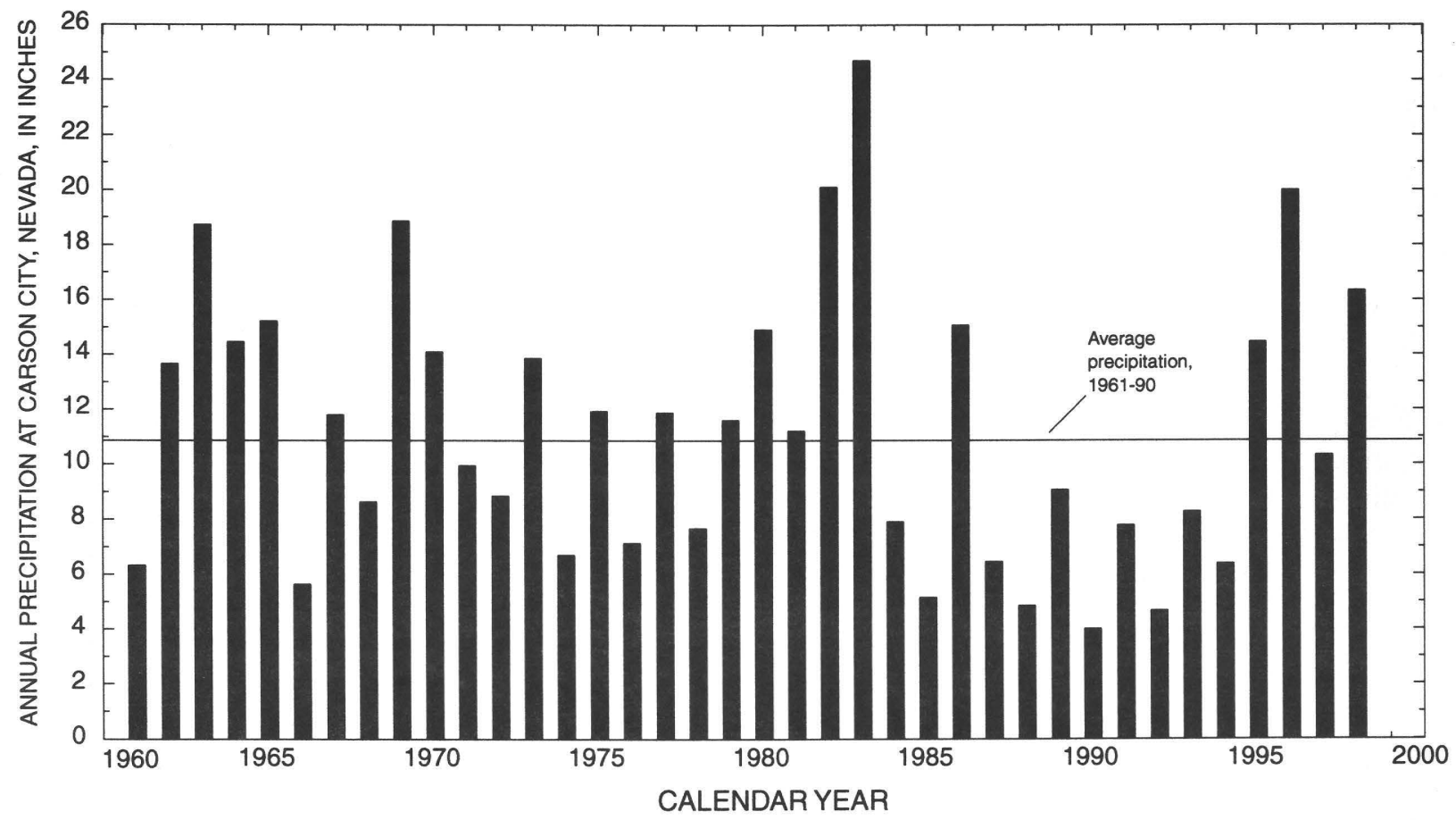

Figure 2. Annual precipitation in Carson City, Nevada, 1960-98, and average annual precipitation, 1961-90. Average annual precipitation from Owenby and Ezell (1992); annual precipitation from National Climatic Center (1961-98).

\section{Ground Water}

\section{Occurrence, Movement, and Water-Level Changes}

Ground water moving through bedrock and basin-fill sediments in Eagle Valley originates as precipitation that falls within the hydrographic area. In the mountains, part of the precipitation evaporates or is transpired by plants, part runs off as streamflow, and part infiltrates weathered or fractured bedrock. Water that infiltrates bedrock moves toward the canyons and seeps into streams or moves down the canyon beneath the stream channels to Eagle Valley. Some ground water in fractured bedrock moves along deeper flow paths into basin-fill sediments (Trexler and others, 1980 , p. 23 and 81 ).

On the valley floor, part of the streamflow from the mountains infiltrates basin-fill sediments beneath the stream channels and irrigated lands, recharging the basin-fill aquifer. Previous studies differ as to the amount of recharge estimated from precipitation on the valley floor: Worts and Malmberg (1966, p. 15) estimated 400 acre-ft/yr, whereas Arteaga and Durbin $(1979$, p. 11) stated that recharge from precipitation was not significant. Basin-fill aquifers are recharged also by infiltration of water or treated effluent applied to lawns.

Depth to ground water is not known in the mountains because few wells exist for measurement. Depth to ground water at the mouths of watersheds tributary to Eagle Valley ranges from almost $200 \mathrm{ft}$ near Vicee Canyon to about $130 \mathrm{ft}$ near Ash Canyon, $85 \mathrm{ft}$ near the base of the Virginia Range, $30 \mathrm{ft}$ near Kings Canyon, and 10 to $20 \mathrm{ft}$ near Clear Creek (fig. 1). Beneath the higher parts of the valley floor, depth to water ranges from about $30 \mathrm{ft}$ about $1 \mathrm{mi}$ northwest of Lone Mountain, to 40 to $50 \mathrm{ft}$ about 1-2 mi north of Stewart. Depth to water is about $5 \mathrm{ft}$ beneath most of the north-central and low-lying parts of the valley floor.

In the northern part of Eagle Valley (fig. 1), ground water moves eastward and southeastward beneath the hydrographic-area divide into Dayton Valley (Worts and Malmberg, 1966, p. 11; Arteaga, 1986, p. 6; Maurer, 1997, p. 31). In the southern part of Eagle Valley, some ground water moves northeastward around the northern end of Prison Hill, and some moves southeastward beneath the hydrographic-area divide into the Carson Valley Hydrographic Area (Worts and Malmberg, 1966, p. 11; Arteaga, 1986, p. 6). 
Ground water in the basin-fill aquifer is discharged by pumping and by evapotranspiration which includes evaporation from bare soil and transpiration by plants. In 1964, about 5,000 acres near the center of the valley were covered with phreatophytes (plants that use ground water) and pasture grasses (Worts and Malmberg, 1966, p. 27). Since that time, many acres of phreatophytes and pasture grasses have been replaced by development. As discussed later in the section titled "Water Budgets," on the basis of indirect evidence, phreatophytes covered about 1,100 acres in 1997. In addition, ground-water pumping has caused water levels to decline, further reducing the amount of groundwater discharged by phreatophytes. Since 1964, ground-water discharge by municipal pumping has increased and discharge by evapotranspiration from natural vegetation has decreased.

In response to municipal pumping, ground-water levels on the northwestern side of Eagle Valley declined in the 1970's (figs. 3A and B). In the southern part of the valley, water levels declined slightly from the mid-1970's to the 1980's (fig. 3C). In both areas, water levels appear to have stabilized in the 1980's; declining slightly during drought conditions from about 1988 to 1994 , and rising 5-10 ft after abovenormal precipitation during 1995-98 (fig. 2). Near the center of the valley, water levels responded to variations in annual precipitation but showed little to no long-term decline (figs. 3D and E). Water levels in a well near Eagle Valley golf course rose in response to irrigation, which began in 1975, and the well began to flow in the early 1980's (fig. 3F). Two other wells also show water-level rises, of about $10 \mathrm{ft}$ since 1975 (figs. $3 \mathrm{G}$ and $\mathrm{H}$ ); however, they are not near the golf course. The water levels at these wells could be rising in response to a change in land use from open land covered with native vegetation to high-density residential land. Rising water levels could be caused by a reduction in evapotranspiration by phreatophytes and increased recharge from lawn irrigation.

\section{Previous Estimates of Ground-Water Recharge}

Recharge to Eagle Valley has been previously estimated by Worts and Malmberg (1966, p. 15), Arteaga and Durbin (1979, p. 14), and Szecsody and others (1983, p. 56 and 71). Maurer and others (1996, p. 27-28) and Maurer and Berger (1997, p. 33) made refined estimates of subsurface inflow and streamflow from the mountains.
Worts and Malmberg (1966, p. 14) used a method developed by Eakin and others (1951) that was based on a relation between precipitation and altitude and an empirical relation between precipitation and recharge. The empirical relation assumes differing percentages of recharge for precipitation-altitude zones. Using slightly different percentages than presented by Eakin and others (1951), Worts and Malmberg (1966, p. 15) estimated potential recharge to be $8,700 \mathrm{acre}-\mathrm{ft} / \mathrm{yr}$, including recharge on the valley floor of $400 \mathrm{acre}-\mathrm{ft} / \mathrm{yr}$. The term "potential" was used because they estimated about half of the streamflow reaching the valley floor flows out of the hydrographic area (Worts and Malmberg, 1966, p. 14).

Arteaga and Durbin (1979, p. 14) used a relation between precipitation and water yield to estimate water yield from watersheds tributary to Eagle Valley. They assumed that the entire water yield from Clear Creek, Kings Canyon, and Ash Canyon watersheds was in the form of surface-water runoff and estimated that recharge from the remaining watersheds was 1,200 acre-ft/yr (Arteaga and Durbin, 1979, p. 23). Estimated recharge from streamflow of Clear, Kings Canyon, and Ash Canyon Creeks, and from agricultural irrigation using that flow was 3,100 acre-ft/yr (Arteaga and Durbin, 1979, p. 25). Arteaga and Durbin (1979, p. 2930) also estimated that recharge from municipal water use averaged about 550 acre-ft from 1967-77, and recharge from irrigation of the city golf course was 700 acre-ft/yr. Recharge from precipitation on the valley floor was assumed to be insignificant (Arteaga and Durbin, 1979, p. 11). Totaling all sources of recharge, a value of about 5,600 acre-ft/yr is obtained, representative of estimated conditions in the early 1970's.

Szecsody and others (1983, p. 56 and 71) estimated that subsurface inflow from the mountains was about 3,900 acre-ft/yr. They based this on increases in electrical conductivity in soil water beneath melting snow packs that they used to estimate evapotranspiration, and did not evaluate infiltration of streamflow on the valley floor.

Maurer and others (1996, p. 27-28) and Maurer and Berger (1997, p. 23) determined that subsurface flow to Eagle Valley does take place from the watersheds of Clear Creek, Kings Canyon, and Ash Canyon, and made refined estimates of subsurface flow and streamflow from all watersheds tributary to Eagle Valley (fig. 1). Subsurface inflow from the mountains is considered inflow to basin-fill aquifers, and is not 


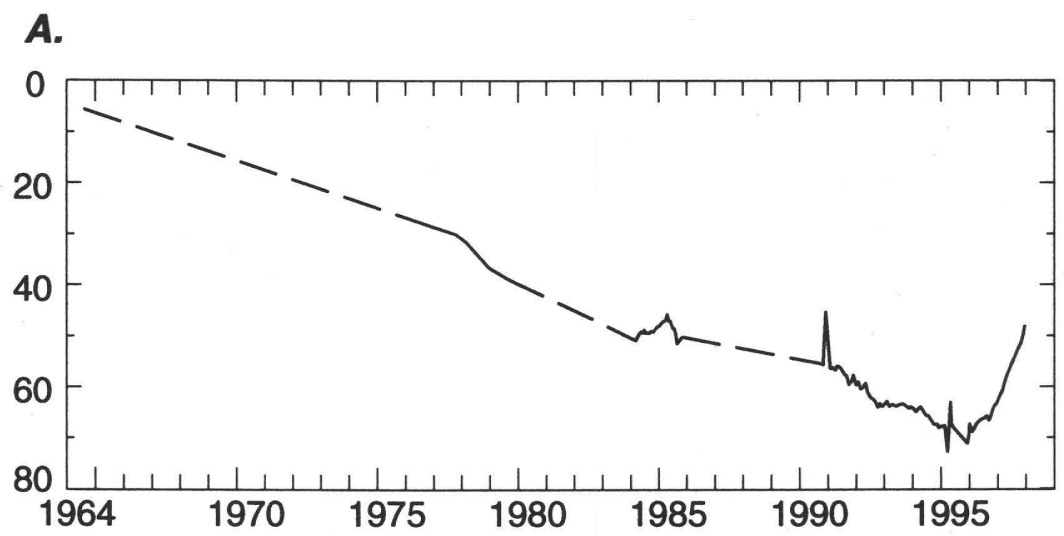

B.

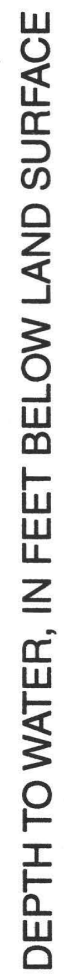

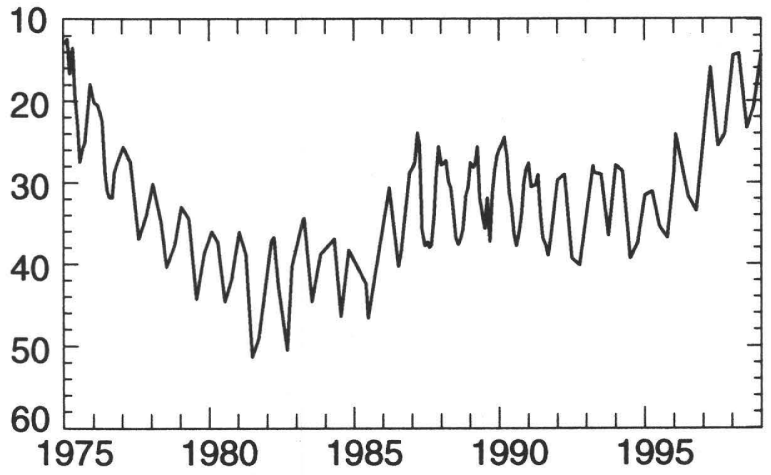

C.

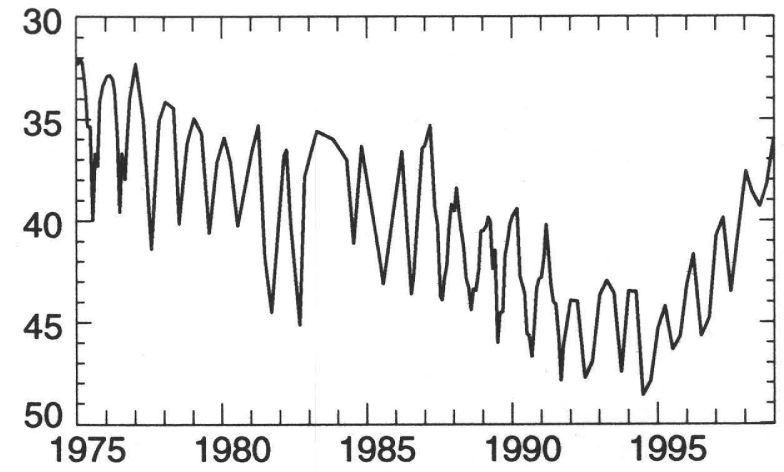

D.

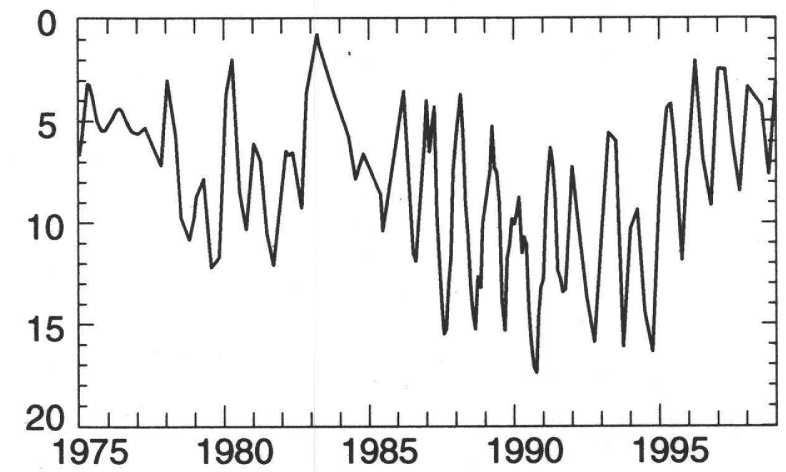

Figure 3. Water-level changes in selected wells, 1964-98 and 1975-98, Eagle Valley, Nevada. Location of wells shown on figure 1. Dashed lines indicate data gaps. Negative values for well $F$ indicate water level above land surface. 


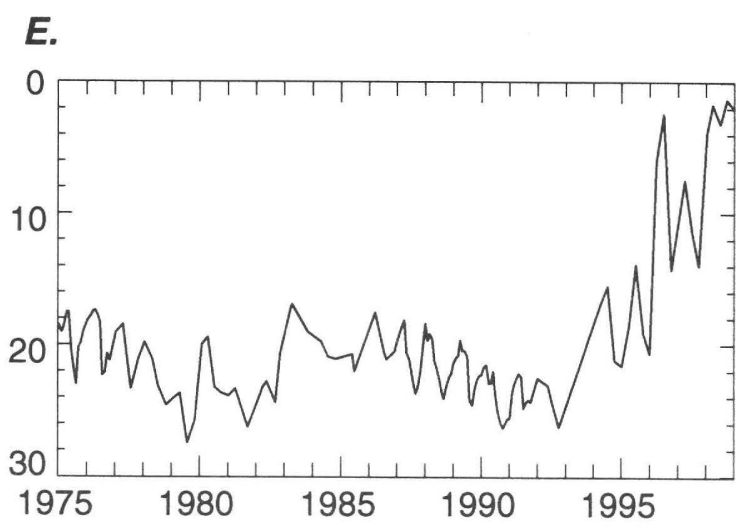

F.

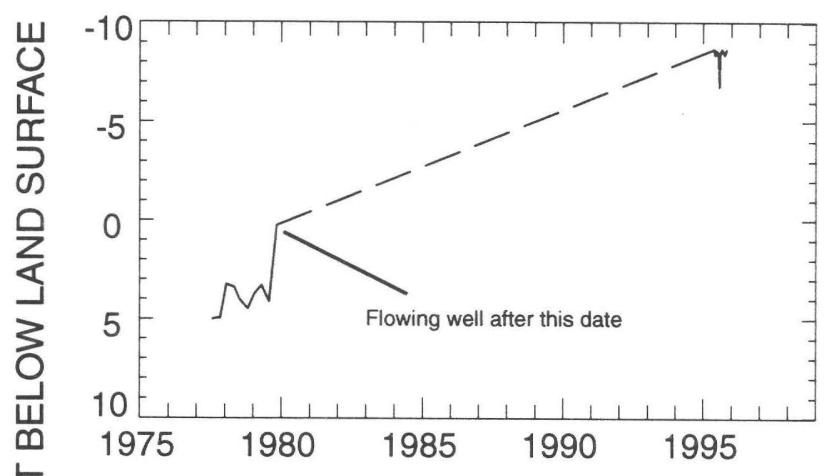

G.

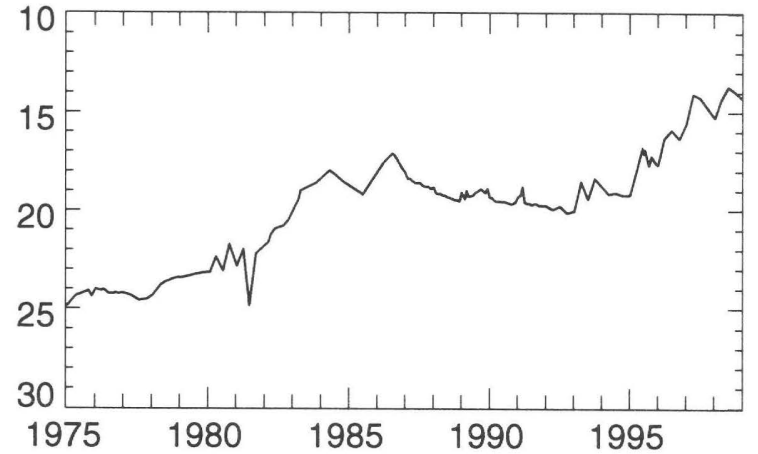

H.

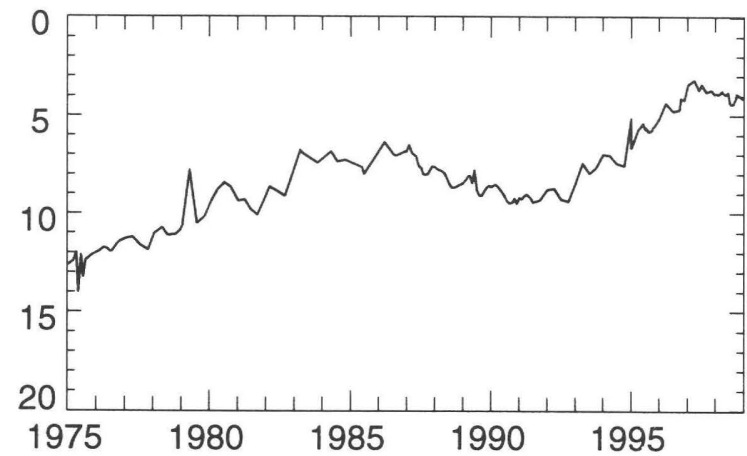

Figure 3. Continued. strictly considered recharge. Recharge is defined as flow that has moved across the water table (Freeze and Cherry, 1979, p. 211).

Maurer and Berger (1997, p. 33) estimated that subsurface inflow from watersheds tributary to the floor of Eagle Valley ranges from 3,200 to 6,100 acre$\mathrm{ft} / \mathrm{yr}$. In that study, a relation developed between precipitation and subsurface inflow suggested that the high-range estimate of subsurface inflow from Kings Canyon (2,300 acre-ft/yr) was probably too high, and that the low-range estimate ( $600 \mathrm{acre}-\mathrm{ft} / \mathrm{yr})$ was more reasonable (Maurer and Berger, 1997, p. 34). Using the low-range estimate for subsurface inflow from Kings Canyon, subsurface inflow from all watersheds ranges from 3,200 to 4,400 acre-ft/yr.

\section{Water Use}

In the mid-1960's, most water use in Eagle Valley was for agriculture using flow from springs and streams draining the Carson Range, and it totaled about 3,700 acre-ft/yr (Worts and Malmberg, 1966, p. 2). Over time, ground-water pumpage for municipal use increased from $950 \mathrm{acre}-\mathrm{ft} / \mathrm{yr}$ in the mid1960's (Worts and Malmberg, 1966, p. 25), to 4,700 acre-ft/yr in 1978 when 75 percent of the pumping was on the northwestern side of the valley (Arteaga, 1986, p. 33-34). In 1987, pumpage reached a maximum of about 7,300 acre-ft/yr and some supply wells were in adjacent Dayton and Carson Valley Hydrographic Areas (Tom Hoffert, Carson City Utilities Department, written commun., 1998). After 1989, municipal water use was increasingly supplemented by surface-water diversions from Kings Canyon and Ash Canyon Creeks, from induction wells adjacent to the Carson River in the Dayton Valley Hydrographic Area, and from surface water imported into Eagle Valley from Marlette and Hobart Lakes (fig. 1). The Marlette-Hobart system originally supplied water for State facilities and currently supplements Carson City's municipal supply. In 1991, Carson City began a program of artificial recharge through infiltration beds in Vicee Canyon using water from the MarletteHobart system. From 1991 through 1997, about 700 acre-ft was recharged; the greatest amount, 400 acre$\mathrm{ft}$, was recharged in 1993.

From 1995 through 1998, municipal groundwater pumpage from Eagle Valley Hydrographic Area averaged about 3,100 acre-ft/yr. This was supplemented by about 1,600 acre-ft/yr of ground water 
pumped from the Dayton and Carson Valley Hydrographic Areas, 1,800 acre-ft/yr of surface water from the Carson River pumped by induction wells in the Dayton Valley Hydrographic Area, about 3,000 acre$\mathrm{ft} / \mathrm{yr}$ of surface-water diversions from Kings Canyon, North Kings Canyon, and Ash Canyon Creeks, and 1,100 acre-ft/yr imported from Marlette and Hobart Lakes (Tom Hoffert, Carson City Utilities Department, written commun., 1998). Total municipal use for 1995 98 averaged about 10,600 acre-ft/yr.

Numerous private wells also pump ground water for domestic, quasi-municipal, commercial, irrigation, industrial, and stock use. Pumpage for all purposes except domestic use totaled 400 acre-ft in 1994, and is relatively constant from year to year (Dillon, 1995, p. 5; Matt Dillon, Nevada Division of Water Resources, oral commun., 1998). In 1998, about 700 domestic wells were in use, estimated from the number of occupied parcels without city services (Leanna Stevens, Carson City Utilities Department, written commun., 1998) and adjusted to include only those within the Eagle Valley Hydrographic Area. Applying an estimated use rate of 1.12 acre-ft/yr (Dillon, 1995, p. 4), domestic pumpage totals about 800 acre-ft/yr. Thus, total ground-water pumpage for Eagle Valley during 1995-98 was about 4,300 acre-ft/yr

Water is exported from Eagle Valley in the form of treated effluent to a reservoir in the Pine Nut Mountains locally called Brunswick reservoir (fig. 1). Effluent is pumped to the reservoir generally during winter months and, since 1997, is returned during summer months to Eagle Valley for irrigation of the Silver Oaks golf course (fig. 1). The treated effluent from the reservoir is used also for irrigation of a golf course and alfalfa, in areas east and south of the Eagle Valley Hydrographic Area, respectively. Effluent directly from the municipal treatment plant also has been used for irrigation of the Eagle Valley golf course since 1975.

\section{RECHARGE FROM INFILTRATION ON THE VALLEY FLOOR}

Basin-fill aquifers beneath the valley floor are recharged from infiltration of streamflow, precipitation, and water applied for irrigation. The volume of recharge is dependent on the volumes of streamflow from the mountains, the volumes of streamflow diverted for municipal use and applied for irrigation, and areas of (1) land irrigated for crops or pasture,
(2) irrigated lawns, (3) impervious surfaces, and

(4) undeveloped or open land. As land and water use on the valley floor change over time, the location and volume of recharge changes.

\section{Infiltration of Streamflow}

Recharge from infiltration of perennial streamflow on the western side of the valley was estimated from periodic streamflow measurements made using standard methods and standard AA and pygmy meters (Rantz, 1982, p. 80). The accuracy of such measurements is within $8-10$ percent of their actual values at most sites. Measurements were made on Clear, Kings Canyon, North Kings Canyon, and Ash Canyon Creeks (fig. 4).

For Clear Creek, measurements were made at eight sites (fig. 4, table 1) downstream from the bedrock/basin-fill contact. Sites 1 through 3 are in a narrow canyon flanked by granitic bedrock, and sites 4 through 8 lie along the flood plain of the creek. Sites 6 and 8 are on a diversion ditch south of the main stem of Clear Creek. Sites 7 and 8 are near the hydrographic-area boundary and measurements of total flow at the two sites are representative of flow out of the hydrographic area. Flow losses or gains between the hydrographicarea boundary and the Carson River are not known.

Three structures divert streamflow from Clear Creek: one between sites 1 and 2, one between sites 3 and 4 , and one upstream from sites 5 and 6 . The upper structure diverts water for irrigation of lawns near Stewart and maintains fire hydrant pressure. The middle structure, prior to 1997, occasionally diverted water for irrigation of lawns at a city park upstream from sites 5 and 6 . The lower structure diverts water for irrigation of pastures in Carson Valley. The middle structure was not operational in June or July 1996 and after January 1997, when flood waters filled the structure with sediment. Water from the two upstream structures is conveyed in buried pipelines not equipped with meters or other means to measure diversion rates.

The streamflow measurements show that stream reaches between the measurement sites change from gaining to losing along the entire reach and from date to date (table 1). Much of the variation calculated in table 1 could be caused by inaccuracies in individual streamflow measurements; however, the variations and lack of consistently large losses suggest that the reach is in close connection with the water table. The larger variations in gains and losses could be caused by 


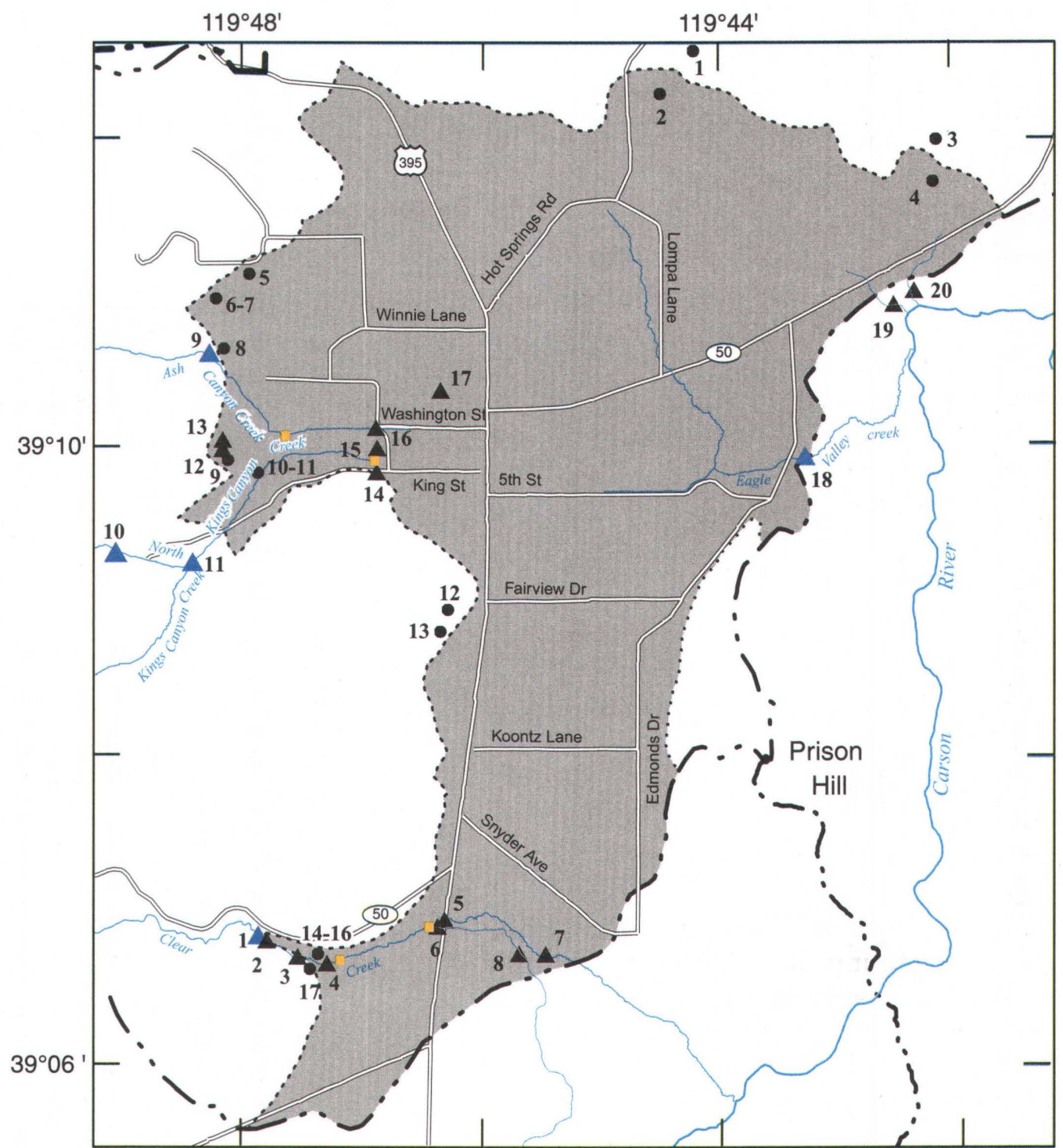

Base from U.S. Geological Survey digital data 1:100,000-scale and 1:24,000-scale (1979-82)

Universal Transverse Mercator projection, Zone 11

from Arte

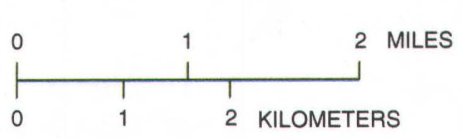

\section{EXPLANATION}
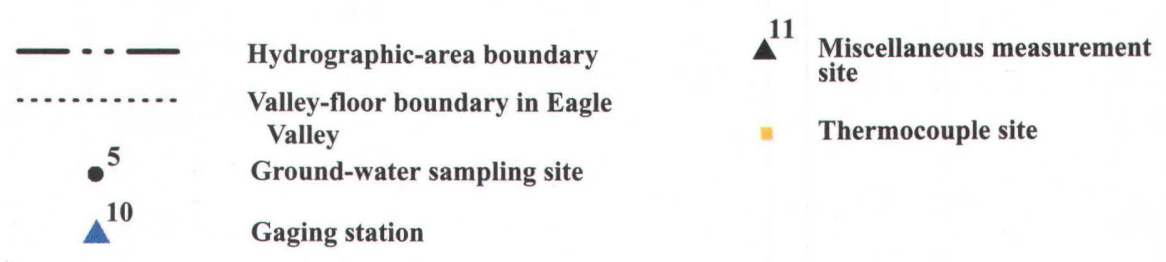
site

E Thermocouple site

$\Delta^{10}$ Gaging station

Figure 4. Location of streamflow measurement sites (site descriptions in tables 1 and 3), thermocouple sites, and water-quality sampling sites in and adjacent to Eagle Valley, Nevada. 
Table 1. Summary of streamflow measurements and gains to and losses from Clear Creek, Eagle Valley, Nevada, 1996-98

[Values are rounded to nearest 0.1 cubic foot per second for flows greater than 1.0 cubic foot per second and to nearest 0.01 cubic foot per second for flows less than 1.0 cubic foot per second. Symbols: --, no measurement; +, gain; -, loss]

\begin{tabular}{|c|c|c|c|c|c|c|c|c|c|c|c|c|c|c|c|c|c|c|c|c|}
\hline \multirow{4}{*}{$\begin{array}{c}\text { Site } \\
\text { (fig. 4) }\end{array}$} & \multicolumn{20}{|c|}{ Discharge (cubic feet per second) } \\
\hline & \multicolumn{10}{|c|}{1996} & \multicolumn{4}{|c|}{1997} & \multicolumn{6}{|c|}{1998} \\
\hline & \multicolumn{2}{|c|}{ January 10} & \multicolumn{2}{|c|}{ May 6} & \multicolumn{2}{|c|}{ June 3} & \multicolumn{2}{|c|}{ July 10} & \multicolumn{2}{|c|}{ August 27} & \multicolumn{2}{|c|}{ July 1} & \multicolumn{2}{|c|}{ September 18} & \multicolumn{2}{|c|}{ April 30} & \multicolumn{2}{|c|}{ June 3} & \multicolumn{2}{|c|}{ July 22} \\
\hline & Flow & $\begin{array}{l}\text { Gain } \\
\text { or loss }\end{array}$ & Flow & $\begin{array}{l}\text { Gain } \\
\text { or loss }\end{array}$ & Flow & $\begin{array}{l}\text { Gain } \\
\text { or loss }\end{array}$ & Flow & $\begin{array}{l}\text { Gain } \\
\text { or loss }\end{array}$ & Flow & $\begin{array}{l}\text { Gain } \\
\text { or loss }\end{array}$ & Flow & $\begin{array}{l}\text { Gain } \\
\text { or loss }\end{array}$ & Flow & $\begin{array}{l}\text { Gain } \\
\text { or loss }\end{array}$ & Flow & $\begin{array}{c}\text { Gain } \\
\text { or loss }\end{array}$ & Flow & $\begin{array}{l}\text { Gain } \\
\text { or loss }\end{array}$ & Flow & $\begin{array}{l}\text { Gain } \\
\text { or loss }\end{array}$ \\
\hline $1^{\mathrm{a}}$ & 3.5 & & 17.1 & & 11.3 & & 4.7 & & 3.0 & & 10.8 & & 6.2 & & -- & & 14.6 & & 7.6 & \\
\hline $2^{b}$ & -- & & -- & & -- & & -- & & -- & & -- & & 5.0 & -1.2 & 16.2 & & 14.4 & -0.2 & 6.3 & -1.3 \\
\hline $3^{\mathrm{c}}$ & 3.9 & +0.4 & 16.4 & -0.7 & 10.1 & -1.2 & 4.6 & -0.1 & 3.3 & +0.3 & 9.3 & -1.5 & 5.6 & +0.6 & 18.1 & +1.9 & 16.4 & +2.0 & 6.7 & +0.4 \\
\hline $4^{d}$ & 3.7 & -0.2 & 13.9 & -2.5 & 9.0 & -1.1 & 4.7 & +0.1 & 3.9 & +0.6 & 8.3 & -1.0 & 6.0 & +0.4 & 20.6 & +2.5 & 15.6 & -0.8 & 7.5 & +0.8 \\
\hline $5^{e}$ & 3.4 & & 11.2 & & 7.7 & & 3.2 & & 2.1 & & 7.2 & & 4.8 & & 18.5 & & 13.6 & & 6.3 & \\
\hline $6^{f}$ & 0.67 & & 2.6 & & 1.5 & & 0.59 & & 0.63 & & 1.9 & & 0.66 & & 0.94 & & 0.41 & & 0.94 & \\
\hline Total sites 5 and 6 & 4.1 & +0.4 & 13.8 & -0.1 & 9.2 & +0.2 & 3.8 & -0.9 & 2.7 & -1.2 & 9.1 & +0.8 & 5.5 & -0.5 & 19.4 & -1.2 & 14.0 & -1.6 & 7.2 & -0.3 \\
\hline $7^{g}$ & 3.3 & & 13.7 & & 6.9 & & 3.0 & & 1.6 & & 6.5 & & 4.2 & & 18.9 & & 14.0 & & 5.7 & \\
\hline $8^{h}$ & 0.38 & & 2.4 & & 1.2 & & 0.46 & & 0.48 & & 1.6 & & 0.55 & & 0.70 & & 0.26 & & 0.70 & \\
\hline Total sites 7 and 8 & 3.7 & -0.4 & 16.1 & +2.3 & 8.1 & -1.1 & 3.5 & -0.3 & 2.1 & -0.6 & 8.1 & -1.0 & 4.8 & -0.7 & 19.6 & +0.2 & 14.3 & +0.3 & 6.4 & -0.8 \\
\hline Net gain/loss ${ }^{i}$ & & +0.2 & & -1.0 & & -3.2 & & -1.2 & & -0.9 & & -2.7 & & -1.4 & & +3.4 & & -0.3 & & -1.2 \\
\hline Percent difference ${ }^{j}$ & & +5.7 & & -5.8 & & -28 & & -26 & & -30 & & -25 & & -23 & & +21 & & -2.1 & & -16 \\
\hline
\end{tabular}

${ }^{a}$ Station number 10310500 , Clear Creek near Carson City, Nev., latitude $39^{\circ} 06^{\prime} 48^{\prime \prime}$, longitude $119^{\circ} 47^{\prime} 50^{\prime \prime}$, in northeast quarter of northeast quarter of northwest quarter of section 1 Township 14 North, Range 19 East.

${ }^{\text {b }}$ Potential diversion between sites 1 and 2 for all dates, latitude $39^{\circ} 06^{\prime} 47^{\prime \prime}$, longitude $119^{\circ} 47^{\prime} 47^{\prime \prime}$, in northeast quarter of northeast quarter of northwest quarter of section 1 , Township 14 North, Range 19 East.

${ }^{\mathrm{c}}$ Latitude $39^{\circ} 06^{\prime} 41^{\prime \prime}$, longitude $119^{\circ} 47^{\prime} 32^{\prime \prime}$, in southwest quarter of northwest quarter of northeast quarter of section 1, Township 14 North, Range 19 East.

${ }^{d}$ Potential diversion between sites 3 and 4 on $01 / 10 / 1996$ and $05 / 06 / 1996$, latitude $39^{\circ} 06^{\prime} 39^{\prime \prime}$, longitude $119^{\circ} 47^{\prime} 17^{\prime \prime}$, in southwest quarter of northeast quarter of northeast quarter of section 1, Township 14 North, Range 19 East.

${ }^{\mathrm{e}}$ Latitude $39^{\circ} 06^{\prime} 55^{\prime \prime}$, longitude $119^{\circ} 46^{\prime} 22^{\prime \prime}$, in southwest quarter of southeast quarter of southeast quarter of section 31 , Township 15 North, Range 20 East.

${ }^{\mathrm{f}}$ Latitude $39^{\circ} 06^{\prime} 54^{\prime \prime}$, longitude $119^{\circ} 46^{\prime} 22^{\prime \prime}$, in southwest quarter of southeast quarter of southeast quarter of section 31 , Township 15 North, Range 20 East.

${ }^{g}$ Latitude $39^{\circ} 06^{\prime} 46^{\prime \prime}$, longitude $11^{\circ} 45^{\prime} 27^{\prime \prime}$, in southeast quarter of northwest quarter of northeast quarter of section 5, Township 14 North, Range 20 East.

${ }^{h}$ Latitude $39^{\circ} 06^{\prime} 42^{\prime \prime}$, longitude $119^{\circ} 45^{\prime} 41^{\prime \prime}$, in southeast quarter of northeast quarter of northwest quarter of section 5, Township 14 North, Range 20 East.

${ }^{\mathrm{i}}$ Net gain or loss between sites 1 or 2 and combined flow at sites 7 and 8 .

${ }^{\mathrm{j}}$ Percent calculated as net gain/loss, divided by flow at site 1 or 2 and multiplied by 100 . 
fluctuations in the water table over time along the stream reach. Fluctuations of the water table are produced by seasonal and annual variations in recharge from precipitation, or could be caused by pumping from wells about 1,000 to $1,500 \mathrm{ft}$ from sites 5,6 , and 7 .

In general, the reach between sites 2 and 3 lost flow during measurements from January 1996 to July 1997, and gained flow during measurements from September 1997 to July 1998. Similarly, the reach between sites 3 and 4 generally lost flow during measurements in 1996-97, with some loss possibly due to diversions, and was strongly gaining in April 1998. This suggests that during the spring of 1998, the water table in granitic bedrock adjacent to sites 2-4 rose in response to wet conditions.

Water-table fluctuations also could cause changes in gains or losses between site 4 and sites 5 and 6 . The reach between site 4 and sites 5 and 6 generally lost flow during measurements, with small gains in January and June 1996 and a larger gain in July 1997. Similarly, the reach between sites 5 and 6 and sites 7 and 8 generally lost flow except for a large gain in May 1996 and small gains in the spring of 1998.

The entire reach (site 1 to sites 7 and 8; fig. 4) generally lost flow except for a small gain in January 1996 and a large gain in April 1998 when the reach adjacent to bedrock was gaining. A linear relation was developed between streamflow at site 1 and streamflow leaving the hydrographic area at sites 7 and 8 (fig. 5). The best-fit line shown on figure 5 can be expressed as a regression equation:

$$
Y=X(1.087)-1.656,
$$

where $Y$ is combined flow at sites 7 and 8 , in cubic feet per second; and

$X$ is flow at site 1 , in cubic feet per second.

The coefficient of determination $\left(r^{2}\right)$, which indicates the decimal-percent of variation in the data accounted for by the equation, is 0.92 . This relation was used to obtain an estimate of stream loss from Clear Creek and remaining outflow from the hydrographic area. Average flow at site 1 for 1995-98

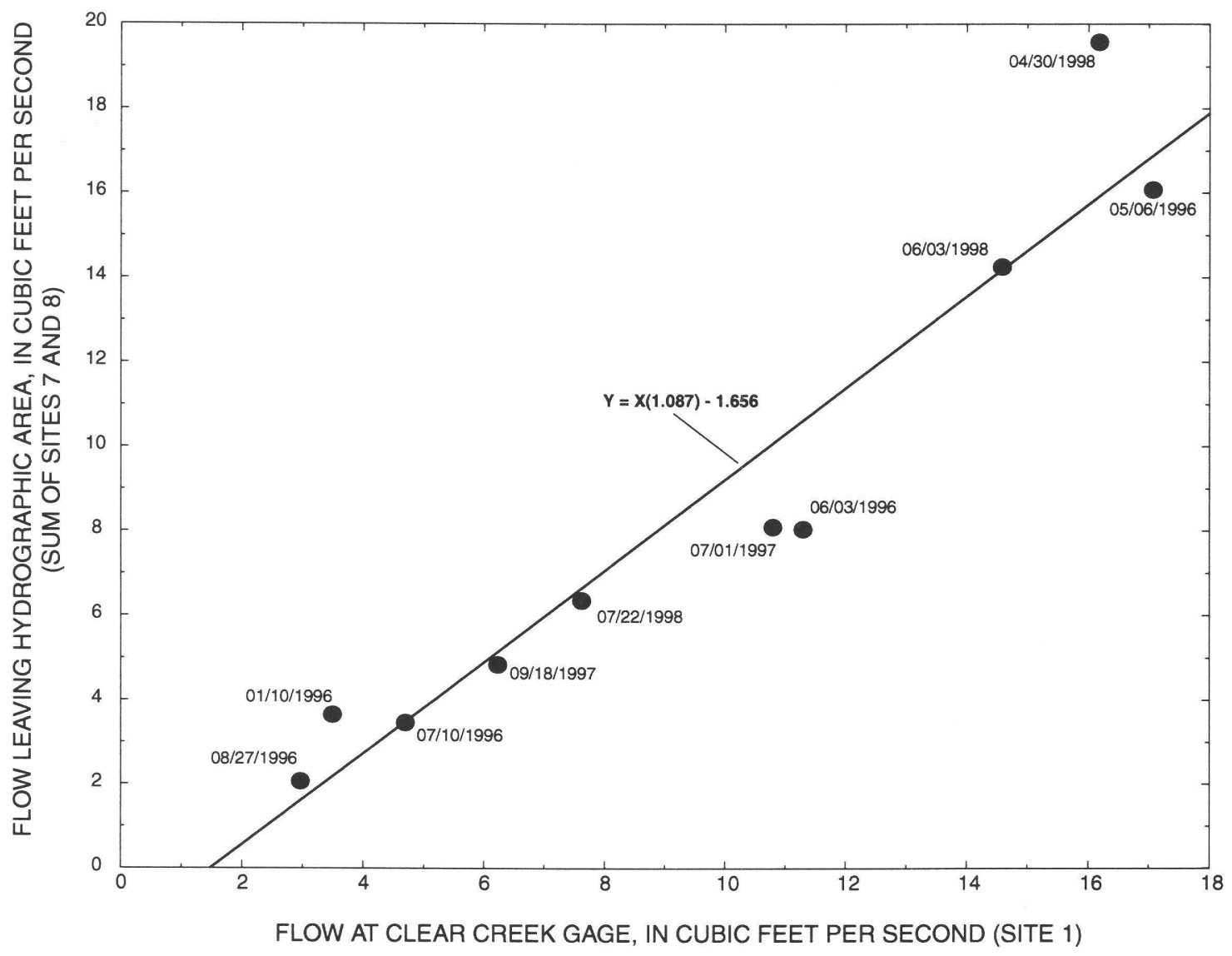

Figure 5. Relation between streamflow of Clear Creek at gaging station and outflow from Eagle Valley Hydrographic Area, Nevada. 
was 6,700 acre-ft/yr $\left(9.27 \mathrm{ft}^{3} / \mathrm{s}\right)$, calculated from data published by the U.S. Geological Survey (1996-99). From equation 1, a value of about $6,100 \mathrm{acre}-\mathrm{ft} / \mathrm{yr}$ (8.42 $\mathrm{ft}^{3} / \mathrm{s}$ ) is obtained for average outflow from the hydrographic area. The amount of this flow that reaches the Carson River is not known. The difference between inflow at site 1 and outflow at sites 7 and 8, about 600 acre-ft/yr, was lost to streamflow infiltration and diversions downstream from site 1 for 1995-98.

Annual diversions from the structure near site 1 were estimated by multiplying the rate and number of lawn applications at Stewart by the area of lawns irrigated with Clear Creek diversions. An application rate of $0.17 \mathrm{in} / \mathrm{hr}$ was measured in 1997, and lawns are watered for an average of 8 hours a day, twice per week from May through September (Larry Hale, Stewart Buildings and Grounds, oral commun., 1998) for a total of about $4.5 \mathrm{ft} / \mathrm{yr}$. The area of lawns watered with the diversion was about 10 acres in 1997, as determined from aerial photography and field verification. Thus, diversions in 1997 and probably similarly in most recent years were about 45 acre-ft.

Streamflow lost to infiltration can supply evapotranspiration adjacent to the channel and the remainder provides recharge to basin-fill aquifers. Vegetation adjacent to Clear Creek consists largely of a narrow band of willows along almost the entire reach from site 1 to sites 7 and 8 . The length of this reach is about $15,500 \mathrm{ft}$ and the average width of willows on each side of the stream is about $20 \mathrm{ft}$. Thus, willows cover about $620,000 \mathrm{ft}^{2}$, or 14 acres adjacent to the creek. Willows are reported to use from 2 to $4 \mathrm{ft} / \mathrm{yr}$ (Robinson, 1970, p. 28). Applied to 14 acres, this range results in evapotranspiration of about 30 to $60 \mathrm{acre}-\mathrm{ft} / \mathrm{yr}$. Including the estimate of diversions from Clear Creek in 1997, 45 acre-ft/yr, total losses range from 75 to about 100 acre$\mathrm{ft} / \mathrm{yr}$. Subtracting this range from the volume of loss using equation 1 ( $600 \mathrm{acre}-\mathrm{ft} / \mathrm{yr}$ ), recharge to basin-fill aquifers in Eagle Valley from Clear Creek during 199598 was about 500 acre-ft/yr (table 2).

For comparison with average conditions, the average flow of Clear Creek was adjusted to average flow of the West Fork Carson River at Woodfords, Calif. (period of record October 1900 to May 1907, 1910-11, and October 1938 through September 1998). Flow was adjusted by multiplying the average flow for the period of record at Clear Creek reported by Preissler and others (1999) by the ratio of (1) the long-term average annual flow of West Fork Carson River to (2) the average annual flow of West Fork Carson River at Woodfords during the period of record at Clear Creek.
Table 2. Summary of estimated recharge from infiltration of streamflow on floor of Eagle Valley, 1995-98 and average conditions

\begin{tabular}{lcc}
\hline \multicolumn{1}{c}{ Source } & \multicolumn{2}{c}{$\begin{array}{c}\text { Recharge } \\
\text { (acre-feet per year) }\end{array}$} \\
\cline { 2 - 3 } & $\mathbf{1 9 9 5 - 9 8}$ & Average \\
\hline Clear Creek & 500 & 700 \\
Kings and Ash Canyon Creeks & 1,700 & 1,000 \\
Ephemeral streams & 1,300 & 900 \\
\cline { 2 - 3 } Total & 3,500 & 2,600 \\
\hline
\end{tabular}

This results in an average of 4,300 acre-ft/yr (5.95 $\mathrm{ft}^{3} / \mathrm{s}$ ). Using this value in equation 1 , a value of about 3,500 acre-ft/yr $\left(4.81 \mathrm{ft}^{3} / \mathrm{s}\right)$ is obtained for outflow from the hydrographic area, and loss is about 800 acre$\mathrm{ft} / \mathrm{yr}$. Assuming that diversions and loss to evapotranspiration have been about the same over the long term (75-100 acre-ft/yr), average recharge from infiltration from Clear Creek is about 700 acre-ft/yr (table 2). A greater loss calculated using the lower average flow for Clear Creek is reasonable because losses were generally lower ( 2 to 16 percent loss and 21 percent gain, table 1) during measurements in 1998 after four wet years than in 1996 and 1997. Flow loss is probably greatest when the adjacent water table is low during dry to normal years and lowest when the water table is high during wet years.

Independent estimates of streamflow infiltration rates from Clear Creek were made from measurements of diurnal temperature fluctuations of streamflow and of soils at increasing depths beneath the streambed, combined with measurements of the vertical hydraulic gradient. Thermocouples (type $\mathrm{T}$, copper constantan wires) were installed at depths of $4,8,12,20$, and 39 in. beneath the streambed at two locations (fig. 4). Vertical hydraulic gradients were measured at each location by driving a pipe into sediments beneath the streambed to selected depths of 20 and 39 in., and measuring the head difference between the stream and within the pipe. A vertical gradient of $0.006 \mathrm{ft} / \mathrm{ft}$ was measured at the upper site, and $0.01 \mathrm{ft} / \mathrm{ft}$ was measured at the lower site.

Diurnal temperature fluctuations of streamflow are caused by the daily variation in solar radiation, with minimum streamflow temperatures in early morning and peak temperatures in late afternoon. Infiltrating streamflow causes diurnal temperature fluctuations in soils; however, the minimum and peak temperatures occur at increasingly later times with depth below the streambed. Also, the difference between minimum and peak temperatures decrease with depth. 
Infiltration rates were calculated at each location by Richard Nishwonger (U.S. Geological Survey, written commun., 1999) using the computer program Variably-Saturated Two-Dimensional Heat Transport model (VS2DH, Healy and Ronan, 1996). The model was used to calculate infiltration rate from simulations of the diurnal temperature variation beneath the streambed at depths corresponding to thermocouple placement. The model used published values for the hydraulic and thermal properties of soils to solve equations for variably saturated water flow and heat transport, producing simulated temperature fluctuations at each depth. Hydraulic and thermal properties in the model were adjusted until simulated temperature fluctuations and vertical gradients matched those observed. Infiltration rates calculated by the model under these conditions ranged from 2.5 to $3.8 \mathrm{ft} / \mathrm{d}$ for the upper site and from 0.025 to $0.37 \mathrm{ft} / \mathrm{d}$ for the lower site. The range in infiltration rates is caused by uncertainty of the thermal properties of the soil.

To estimate annual infiltration beneath the streambed, the range in rates was applied to the streambed area estimated for upper and lower stream reaches adjacent to the two thermocouple locations. The upper reach extends from site 1 to a point halfway between sites 4 and 5, and the lower reach extends from that point to sites 7 and 8 . Streambed area was estimated by multiplying the average stream width observed during streamflow measurements at sites 1 through 8 by the distance between measurement sites. The area of the upper stream reach was estimated to be $38,900 \mathrm{ft}^{2}$ (0.9 acre), and the area of the lower reach was about $64,600 \mathrm{ft}^{2}$ (1.5 acres). By applying the range of infiltration rates for each reach, annual infiltration was estimated to be from 800 to $1,200 \mathrm{acre}-\mathrm{ft} / \mathrm{yr}$ beneath the upper reach, and from 14 to 200 acre-ft/yr beneath the lower reach, resulting in a total volume ranging from 800 to about $1,400 \mathrm{acre}-\mathrm{ft} / \mathrm{yr}$. Subtracting the estimate of evapotranspiration, from 30 to 60 acre$\mathrm{ft} / \mathrm{yr}$, recharge estimated using the temperature data ranges from about 700 to $1,300 \mathrm{acre}-\mathrm{ft} / \mathrm{yr}$. The lower estimate based on temperature measurements agrees reasonably well with the estimate based on the relation between inflow and outflow from streamflow measurements-500 acre-ft/yr for 1995-98 and 700 acre- $\mathrm{ft} / \mathrm{yr}$ for average conditions. The values obtained from the relation based on streamflow measurements will be used for water-budget estimates. However, estimates from measuring streambed temperature provide an economic method for estimating recharge at Clear Creek.
For Kings Canyon, North Kings Canyon, and Ash Canyon Creeks, streamflow measurements were made at three sites along the mountain front (sites 9-11, fig. 4 , table 3 ) and at four sites where streamflow remaining after Carson City diversions and irrigation of pastures enters subsurface culverts for storm drainage beneath urban Carson City (sites 14-17). Streamflow is diverted for municipal use from North Kings Canyon and Ash Canyon Creeks (sites 12 and 13). The diversion rate was determined from in-line flow meters measuring water delivered to the Carson City treatment plant (site 12; Cyril Ouilette, Carson City Utilities Department, oral communs., 1996-98), and checked by streamflow measurements for North Kings Canyon Creek (site 10, table 3). Downstream from municipal diversions, streamflow from North Kings Canyon Creek is tributary to Kings Canyon Creek and is included in flow measured at site 11. Water is diverted in open ditches from Kings Canyon Creek and by a combination of ditches and pipelines from Ash Canyon Creek for flood irrigation of about 220 acres of pasture lands on the western side of Carson City (fig. 7).

East of the Carson City storm-drain system, about 1 mi east of U.S. Highway 395, streamflow emerges from the culverts and flows through open channels where depth to ground water is approximately coincident with the streambed (less than $5 \mathrm{ft}$ below land surface). Infiltration of streamflow along this reach is probably minimal. During measurements, total outflow to drains west of the drain system (table 3) was less than daily mean flow recorded at Eagle Valley creek (site 18, fig. 4) except during July and August of 1997 and 1998, when streamflow east of the drain system may have been used for irrigation. As will be discussed in the section titled "Infiltration of Precipitation and Water Applied for Irrigation," chloride concentrations in soils above the water table show that net recharge in this area is minimal.

Streamflow measurements show that the streams lose flow to infiltration over the entire reach west of Carson City. The volume of water lost to infiltration beneath streams, ditches, and flood-irrigated pastures on the western side of Eagle Valley can be determined by subtracting diversions for municipal use (sites 12 and 13) and flow measured at the storm-drain system (sites 14-17), from the total inflow at the mountain front (sites $9-11$, table 3 ). From 0.9 to $5.9 \mathrm{ft}^{3} / \mathrm{s}$ were lost to infiltration during measurements on the western side of Eagle Valley (table 3). The net loss ranged from 37 to 100 percent of the flow remaining after municipal 
Table 3. Summary of streamflow measurements, municipal diversions, and streamflow losses from Kings and Ash Canyon Creeks, Eagle Valley, Nevada, 1996-98

[Values are rounded to nearest 0.1 cubic foot per second for flows greater than 1.0 cubic foot per second, and to nearest 0.01 cubic foot per second for flows less than 1.0 cubic foot per second.]

Discharge (cubic feet per second)

$\begin{array}{cccc}\text { Site } & 1996 & 1997 & 1998\end{array}$

March 26 July 9 June 26 July 2 August 25 April 29 June 2 July 1 July 31 August 7 August 18 August 28 September 11

\begin{tabular}{|c|c|c|c|c|c|c|c|c|c|c|c|c|c|}
\hline \multicolumn{14}{|c|}{ Inflow } \\
\hline $9^{a}$ & 4.4 & 6.4 & 6.8 & 6.5 & 3.9 & 6.2 & 6.2 & 6.8 & 5.2 & 4.9 & 4.5 & 4.1 & 4.5 \\
\hline $10^{\mathrm{b}}$ & 1.8 & 4.0 & 4.2 & 0 & 3.3 & 2.1 & 2.0 & 2.8 & 1.1 & .9 & 3.3 & .9 & .9 \\
\hline $11^{\mathrm{c}}$ & 1.3 & .73 & 1.2 & 5.5 & .89 & .75 & .85 & 1.3 & 2.8 & 2.6 & .53 & 2.5 & 2.4 \\
\hline Total & 7.5 & 11.1 & 12.2 & 12.0 & 8.1 & 9.1 & 9.1 & 10.9 & 9.1 & 8.4 & 8.3 & 7.5 & 7.8 \\
\hline \multicolumn{14}{|c|}{ Municipal diversions } \\
\hline $12^{d}$ & 1.8 & 4.0 & 4.2 & 0 & 3.3 & 2.1 & 2.0 & 2.8 & 1.1 & .9 & 3.3 & .9 & .9 \\
\hline $13^{e}$ & 2.2 & 2.7 & 3.0 & 5.8 & 2.2 & 5.8 & 4.0 & 3.5 & 2.0 & 3.1 & 3.5 & 2.7 & 2.7 \\
\hline Total & 4.0 & 6.7 & 7.2 & 5.8 & 5.5 & 7.9 & 6.0 & 6.3 & 3.1 & 4.0 & 6.8 & 3.6 & 3.6 \\
\hline \multicolumn{14}{|c|}{ Flow remaining after diversions ${ }^{f}$} \\
\hline & 3.5 & 4.4 & 5.0 & 6.2 & 2.6 & 1.2 & 3.1 & 4.6 & 6.0 & 4.4 & 1.5 & 3.9 & 4.2 \\
\hline \multicolumn{14}{|c|}{ Outflow } \\
\hline $14^{g}$ & 1.2 & .19 & .13 & 1.4 & 0 & .23 & .18 & .02 & .05 & .007 & .02 & 0 & 0 \\
\hline $15^{\mathrm{h}}$ & 0 & 0 & .006 & 0 & .02 & .01 & .01 & 1.5 & 0 & 0 & .19 & 0 & 0 \\
\hline $16^{\mathrm{i}}$ & 1.0 & .01 & .04 & .02 & .22 & .03 & .02 & 0 & 0 & 0 & 0 & 0 & 0 \\
\hline $17^{\mathrm{j}}$ & 0 & 0 & .38 & 0 & 0 & .005 & .006 & 0 & 0 & .34 & 0 & 0 & 0 \\
\hline Total & 2.2 & .20 & .56 & 1.4 & .24 & .28 & .22 & 1.5 & .05 & .35 & .21 & 0 & 0 \\
\hline \multicolumn{14}{|c|}{ Net loss ${ }^{k}$} \\
\hline & 1.3 & 4.2 & 4.4 & 4.8 & 2.4 & .92 & 2.9 & 3.1 & 5.9 & 4.0 & 1.3 & 3.9 & 4.2 \\
\hline \multicolumn{14}{|c|}{ Net loss, as percent of flow remaining after diversions ${ }^{1}$} \\
\hline & 37 & 95 & 88 & 77 & 92 & 75 & 93 & 67 & 98 & 91 & 87 & 100 & 100 \\
\hline \multicolumn{14}{|c|}{ Daily mean flow of Eagle Valley creek ${ }^{\mathrm{m}}$} \\
\hline & 2.7 & .23 & 2.9 & .43 & .05 & 1.1 & .84 & .63 & .23 & .11 & .09 & .09 & .34 \\
\hline
\end{tabular}

${ }^{a}$ Station number 10311200, Ash Canyon Creek near Carson City, Nev., latitude 39 10’35", longitude 119 48'17", in southwest quarter of northwest quarter of southwest quarter of section 12, Township 15 North, Range 19 East.

${ }^{\text {b }}$ Station number 10311089, North Fork Kings Canyon Diversion near Carson City, Nev., latitude 39 09'18", longitude 119 48'58", in southeast quarter of northeast quarter of northwest quarter of section 23, Township 15 North, Range 19 East.

' Station number 10311100, Kings Canyon Creek near Carson City, Nev., latitude 39 09'14", longitude 119 48'24", in southeast quarter of northeast quarter of northeast quarter of section 23, Township 15 North, Range 19 East.

${ }^{\mathrm{d}}$ Municipal diversion from North Kings Canyon Creek (Cyril Ouilette, Carson City Utilities Department, oral commun., 1996-98), equal to flow measured at site 10 .

${ }^{\mathrm{e}}$ Municipal diversion from Ash Canyon Creek (Cyril Ouilette, Carson City Utilities Department, oral commun., 1996-98).

${ }^{\mathrm{f}}$ Value is total flow minus total municipal diversions.

g Drain near King Street, latitude $39^{\circ} 09^{\prime} 51^{\prime \prime}$, longitude $119^{\circ} 46^{\prime} 53^{\prime \prime}$, in northwest quarter of northeast quarter of southwest quarter of section 18 , Township 15 North, Range 20 East.

${ }^{h}$ Drain near Anderson Ranch, latitude 39 $09^{\prime} 58^{\prime \prime}$, longitude 119 $46^{\prime} 53^{\prime \prime}$, in southwest quarter of southeast quarter of northwest quarter of section 18, Township 15 North, Range 20 East.

i Drain near Washington Street, latitude 39 $10^{\prime} 07^{\prime \prime}$, longitude $119^{\circ} 46^{\prime} 52^{\prime \prime}$, in southwest quarter of northeast quarter of northwest quarter of section 18 , Township 15 North, Range 20 East.

${ }^{\mathrm{j}}$ Drain near Fleischman Street, latitude 39 $10^{\prime} 20^{\prime \prime}$, longitude $11^{\circ} 46^{\prime} 19^{\prime \prime}$, in northwest quarter of northeast quarter of northeast quarter of section 18 , Township 15 North, Range 20 East.

${ }^{\mathrm{k}}$ Value is total flow remaining after diversions minus total outflow.

${ }^{1}$ Percent calculated as net loss, divided by total flow remaining after diversions and multiplied by 100 .

${ }^{\mathrm{m}}$ From Bostic and others (1997, p. 175), Bonner and others (1998, p. 168), and Preissler and others (1999). 
diversions (table 3 ). The low loss rate measured in March 1996 is probably more representative of conditions during winter months when streamflow is not extensively diverted for flood irrigation.

Variations in the percent loss during summer months could be caused by the length of time pastures had been irrigated during measurements, or by fluctuations in the underlying water table from spring to late summer. On July 31, 1998, flood irrigation of fields at the northern end of pastures began and the net loss was 98 percent. One week later, on August 7, the same fields were being irrigated and the net loss decreased to 91 percent as soils became more saturated. The net loss generally increased from spring to late summer as the local water table declined beneath irrigated fields. In 1997, the net loss was 88 percent in June, 77 percent in July, and 92 percent in mid-August. In 1998, the net loss varied through spring and summer and was 100 percent in late August and September.
A linear relation was developed between the net loss and flow at the mountain front remaining after diversions, excluding values for March 1996 (fig. 6). The best-fit line can be expressed as a regression equation:

$$
Y=X(0.868)+0.092
$$

where $Y$ is net loss, in cubic feet per second, and

$X$ is flow remaining after municipal diversions, in cubic feet per second.

The regression equation has a coefficient of determination $\left(r^{2}\right)$ of 0.90 . The equation is applicable to conditions during the irrigation season, generally from April through September. Average flow during those months for the 1995-98 period at Ash Canyon Creek (site 9) was about 2,400 acre-ft and at Kings Canyon Creek (site 11) was about 500 acre-ft as calculated from data published by the U.S. Geological Survey (1996-99). Diversions for municipal use from Ash Canyon Creek during the same period averaged

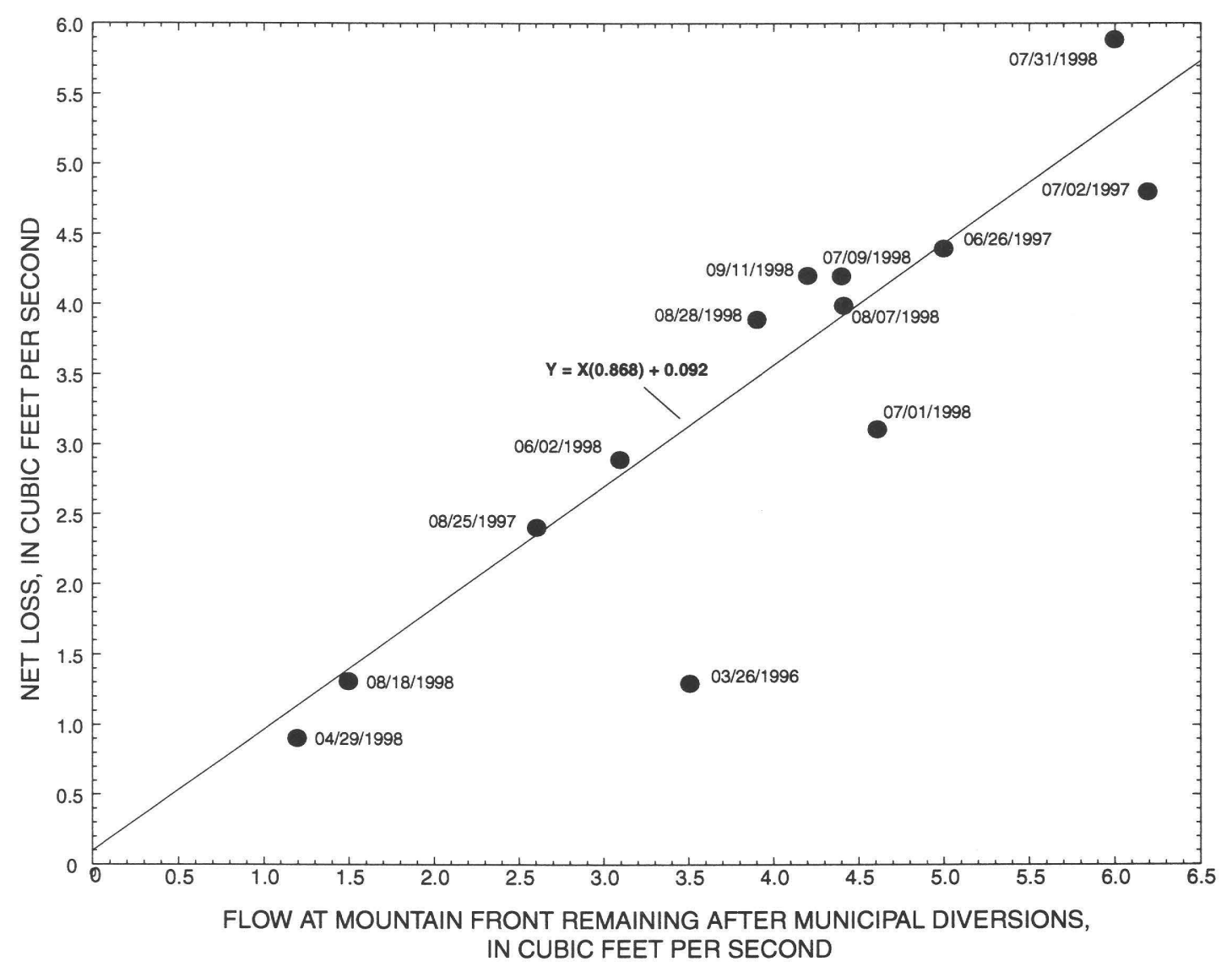

Figure 6. Relation between streamflow remaining after municipal diversions and streamflow loss from Kings Canyon and Ash Canyon Creeks, Eagle Valley, Nevada. 
about 800 acre-ft/yr (Tom Hoffert, Carson City Utilities, written commun., 1997). Thus, the total flow from Kings Canyon and Äsh Canyon Creeks remaining after diversions was about 2,100 acre-ft/yr $\left(5.83 \mathrm{ft}^{3} / \mathrm{s}\right)$ from April through September (182 days). Using equation 2, net loss from Kings Canyon and Ash Canyon Creeks from April through September was about 1,900 acre$\mathrm{ft} / \mathrm{yr}\left(5.15 \mathrm{ft}^{3} / \mathrm{s}\right)$ during $1995-98$.

During the non-irrigation season, an estimate of flow lost to infiltration through the streambed and beneath active irrigation ditches was obtained from measurements of diurnal temperature fluctuations of streamflow and at increasing depths beneath the streambed. Thermocouples were installed at depths of $4,8,12,20$, and $39 \mathrm{in}$. beneath the streambed at two locations (fig. 4).

As was done for Clear Creek, infiltration rates were calculated using VS2DH, the measured temperature variations, and measurements of the vertical hydraulic gradient at each site. A vertical hydraulic gradient of $1.0 \mathrm{ft} / \mathrm{ft}$ was measured at the upper site, and $0.7 \mathrm{ft} / \mathrm{ft}$ was measured at the lower site. The gradients are larger than those measured at Clear Creek, indicating that the stream losses may be larger. Estimated infiltration rates ranged from 1.8 to $2.9 \mathrm{ft} / \mathrm{d}$ at the upper site, and from 1.0 to $2.5 \mathrm{ft} / \mathrm{d}$ at the lower site.

Streambed area was determined from measured widths of streams and ditches active during winter months, multiplied by the distance between measurement sites. For Kings Canyon Creek, infiltration beneath the reach from site 11 to 0.7 mi downstream is upstream from the valley-floor boundary and included in the estimate of subsurface flow made by Maurer and others (1996, p. 31). The area of this reach was not included in the overall estimate of streambed area. The range in infiltration rates obtained at the upper thermocouple location was applied to streams and ditches upstream from a point halfway between the two thermocouple locations, and the range obtained at the lower thermocouple location was applied to streams and ditches downstream from the halfway point. During winter months, streamflow from Ash Canyon Creek is used almost entirely for municipal supply except during storms when turbidity precludes its use. Thus, infiltration is lost mainly through the bed of Kings Canyon Creek and the ditches it supplies. The streambed area estimated for the upper reach was 7,200 $\mathrm{ft}^{2}(0.165$ acre $)$, and for the lower reach was $7,100 \mathrm{ft}^{2}$ ( 0.163 acre). Applying the range in infiltration rates to these areas for the 182-day non-irrigation season results in an estimate of infiltration ranging from 50 to 90 acre- $\mathrm{ft}$ for the upper reach and from 30 to 70 acre- $\mathrm{ft}$ for the lower reach, totaling 80 to 160 acre-ft for the non-irrigation season. Adding these values to the estimate of infiltration during the irrigation season $(1,900$ acre-ft/yr), annual infiltration from Kings Canyon and Ash Canyon Creeks was about 2,000 to 2,100 acre-ft/yr during 1995-98.

Part of this loss, for the $0.7 \mathrm{mi}$ reach of Kings Canyon Creek downstream from site 11 and upstream from the valley floor boundary, has been included in estimates of subsurface inflow from Kings Canyon (Maurer and others, 1996, p. 31). For this reason, the estimate of infiltration during the irrigation season was decreased to account for infiltration beneath the reach 0.7 mi downstream from site 11 on Kings Canyon Creek. The area of that reach is about $9,000 \mathrm{ft}^{2}(0.2$ acre), and applying the range of 1.8 to $2.9 \mathrm{ft} / \mathrm{d}$ obtained at the upper thermocouple site, infiltration from the reach ranges from about 70 to 100 acre- $\mathrm{ft}$ for the 182day irrigation season. Subtracting these volumes from the estimates of total annual infiltration, 2,000 to 2,100 acre- $\mathrm{ft} / \mathrm{yr}$, infiltration on the floor of Eagle Valley during 1995-98 was from 1,900 to 2,000 acre-ft/yr.

Water lost to infiltration may, in turn, be lost to evapotranspiration from pasture grasses irrigated using streamflow from Kings Canyon and Ash Canyon Creeks. Pastures irrigated west of the storm-drain system total 220 acres (table 4). Using an evapotranspiration rate of 1.0 to $1.5 \mathrm{ft} / \mathrm{yr}$ for pasture grasses (Worts and Malmberg, 1966, p. 27), about 200 to 300 acre-ft/yr of the streamflow infiltration is lost to evapotranspiration. Subtracting these volumes from the estimates of infiltration on the valley floor, recharge from streamflow infiltration from Kings Canyon and Ash Canyon Creeks was about 1,700 acre-ft/yr during 1995-98 (table 2).

For comparison with average conditions, average flow, adjusted to long-term flow of the West Fork Carson River at Woodfords, Calif., from April through September for Kings Canyon Creek is 500 acre- $\mathrm{ft} / \mathrm{yr}$, for Ash Canyon Creek is 1,400 acre-ft/yr, and diversions from Ash Canyon Creek averaged 500 acre-ft/yr from 1992, when diversions began, to 1998 (Tom Hoffert, Carson City Utilities Department, written commun., 1999). Average flow remaining after municipal diversions is 1,400 acre- $\mathrm{ft} / \mathrm{yr}\left(3.88 \mathrm{ft}^{3} / \mathrm{s}\right)$. From equation 2, the average net loss is 1,250 acre- $\mathrm{ft} / \mathrm{yr}$ (3.46 $\left.\mathrm{ft}^{3} / \mathrm{s}\right)$. Assuming the same additional infiltration losses during winter months for 1995-98 (80-160 acre-ft/yr), 
Table 4. Areas of land use on floor of Eagle Valley, 1997, and areas of non-saline and saline soils within open, residential, and impervious areas

\begin{tabular}{|c|c|}
\hline Land-use type ${ }^{a}$ & $\begin{array}{c}\text { Area } \\
\text { (acres) }\end{array}$ \\
\hline \multicolumn{2}{|l|}{ Open area } \\
\hline Non-saline soils & 4,300 \\
\hline Saline soils & 860 \\
\hline Total & 5,160 \\
\hline \multicolumn{2}{|l|}{ High-density residential $^{\mathrm{b}}$} \\
\hline Lawns & 1,110 \\
\hline Impervious surfaces & 1,970 \\
\hline Total & 3,080 \\
\hline \multicolumn{2}{|l|}{ Low-density residential ${ }^{b}$} \\
\hline Lawns & 1,240 \\
\hline \multicolumn{2}{|l|}{ Open area } \\
\hline Non-saline soils & 1,230 \\
\hline Saline soils & 210 \\
\hline Total & 1,440 \\
\hline Impervious surfaces & 760 \\
\hline Total & 3,440 \\
\hline Impervious surfaces, non-residential & 910 \\
\hline \multicolumn{2}{|l|}{ Pasture } \\
\hline Heavily irrigated & 220 \\
\hline Minimal irrigation with saline soils & 430 \\
\hline Total & 650 \\
\hline Golf courses & 320 \\
\hline Lawns (Mills Park) & 40 \\
\hline Total, valley floor area & 13,600 \\
\hline \multicolumn{2}{|l|}{ Totals, by land-use category ${ }^{c}$} \\
\hline \multicolumn{2}{|l|}{ Open area } \\
\hline Non-saline soils & 5,500 \\
\hline Saline soils & 1,100 \\
\hline Total & 6,600 \\
\hline Lawns & 2,400 \\
\hline Impervious surfaces & 3,600 \\
\hline Pasture & 650 \\
\hline Golf courses & 320 \\
\hline \multicolumn{2}{|c|}{$\begin{array}{l}{ }^{\text {a }} \text { Determined from aerial photography taken February } 1992 \text { and } \\
\text { January } 1997 . \text { Extent of saline soils from Candland (1979, p. } 31 \text { and 42) } \\
\text { and estimated from areas of phreatophytes and depth to water of less than } \\
5 \text { feet in } 1964 \text { (Worts and Malmberg, 1966, figs. } 5 \text { and 7). }\end{array}$} \\
\hline \multicolumn{2}{|c|}{$\begin{array}{l}{ }^{\mathrm{b}} \text { Subtotals for residential land estimated from analysis of aerial } \\
\text { photography for five locations in high- and low-density residential land. } \\
\text { High-density residential land averaged } 36 \text { percent lawns, } 64 \text { percent } \\
\text { impervious surfaces; low-density residential land averaged } 36 \text { percent } \\
\text { lawns, } 42 \text { percent open area, } 22 \text { percent impervious surfaces. }\end{array}$} \\
\hline
\end{tabular}

average annual infiltration is 1,300 to 1,400 acre-ft/yr. If infiltration upstream from the valley floor along Kings Canyon Creek (70 to 100 acre-ft/yr) and evapotranspiration losses (200-300 acre-ft/yr) also are similar to those of 1995-98, recharge from Kings Canyon and Ash Canyon Creeks for average conditions is about 1,000 acre-ft/yr (table 2).

Flow from ephemeral streams that drain the remaining watersheds tributary to Eagle Valley was estimated by Maurer and Berger (1997, p. 32-33) to total about 900 acre-ft/yr, on the basis of the map of average annual precipitation developed by Arteaga and Durbin (1979, p. 16). During the wet years of 1995-98, ephemeral streamflow was probably greater than 900 acre- $\mathrm{ft} / \mathrm{yr}$. The combined gaged flow of the perennial streams, Clear Creek, Kings Canyon Creek, North Kings Canyon diversions, and Ash Canyon Creek averaged about 13,000 acre-ft/yr from 1995-98 as calculated from data published by the U.S. Geological Survey (1996-99). Flow of North Kings Canyon Creek remaining after diversions is tributary to and included in the flow of Kings Canyon Creek. The combined average flow of these perennial streams, adjusted to the long-term flow of the West Fork Carson River, is about 9,000 acre-ft/yr, and flow from 1995-98 was about 140 percent of this average. Assuming that the flow of ephemeral streams increased by the same amount during 1995-98, ephemeral streamflow was 140 percent of $900 \mathrm{acre}-\mathrm{ft} / \mathrm{yr}$, or about 1,300 acre-ft/yr. The bulk of this ephemeral streamflow probably infiltrates stream channels near the mountain front and becomes recharge (table 2).

\section{Infiltration of Precipitation and Water Applied for Irrigation}

Recharge from infiltration of precipitation and irrigation water was estimated from the concentration of chloride in soil profiles above the water table at 16 sites. Estimates of recharge at the sites were applied to areas of similar land use on the floor of Eagle Valley.

An initial distribution of land use was determined from aerial photographs at a scale of 1:7,200 taken in February 1992. This distribution was updated when photography taken in January 1997 became available because of rapid land-use changes (fig. 7). Land use was divided into categories of (1) open land covered by native vegetation; (2) impervious land covered by asphalt, concrete, or commercial buildings; (3) highand (4) low-density residential land; (5) irrigated 


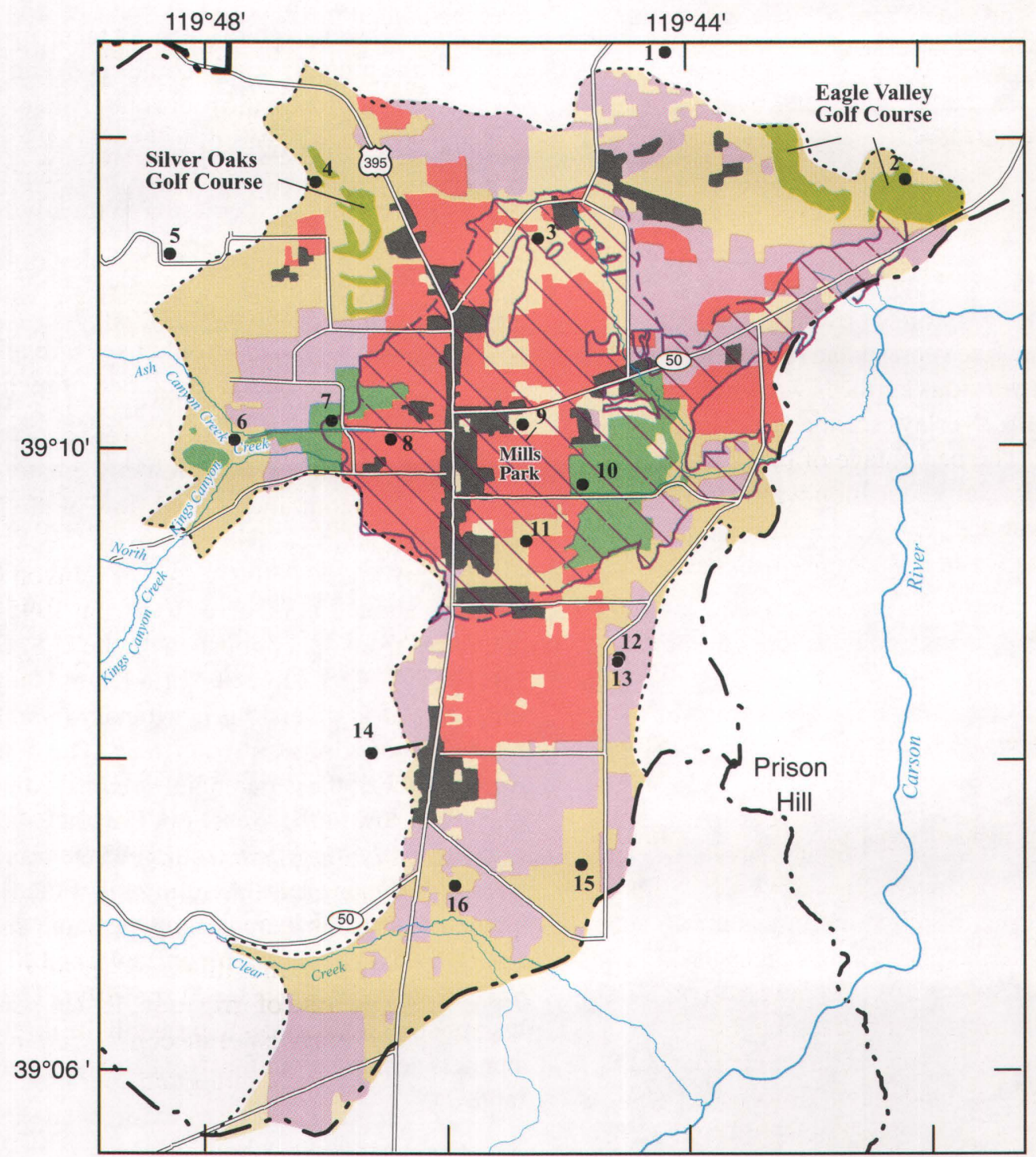

Base from U.S. Geological Survey digital data 1:100,000-scale and 1:24,000-scale (1979-82),

Universal Transverse Mercator projection, Zone 11,

Land use from 1:7,200 scale aerial photography taken January 1997

Hydrographic areas from Arteaga and Durbin (1979)

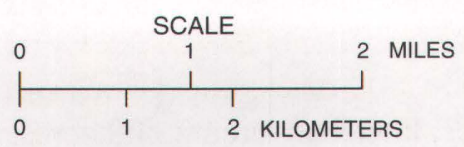

EXPLANATION

Saline soils - Dashed where inferred from Worts and Malmberg (1966, figs. 5 and 7)

Golf course

Open land

Impervious surface

Irrigated pasture

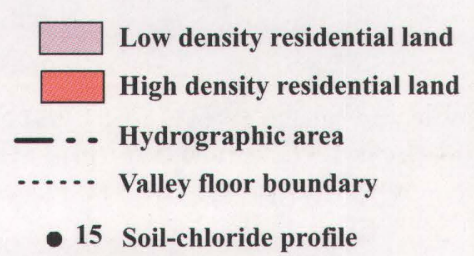

Figure 7. Distribution of land use on floor of Eagle Valley, Nevada, 1997, including areas having saline soils and location of soil-chloride profile sites. Soils distribution modified from Candland (1979). Mills Park, shown as open area, is irrigated lawn. 
pastures; and (6) golf courses. High-density residential land is covered by impervious surfaces of homes, driveways, sidewalks, and streets, and by lawns or heavily landscaped areas. Low-density residential land is similar but also includes areas of open land, which are barren or covered by native vegetation.

Impervious surfaces and lawns or open areas within the categories of high- and low-density residential land were determined from overlays of aerial photography made for five representative locations for each category. Impervious surfaces were blackened on the overlays and the overlays scanned to obtain a black and white image. The percentage of black and white within each representative location was determined from the scanned image. This percentage was then used for all areas of high- and low-density residential land.

For the five locations representative of high-density residential land, irrigated lawns ranged from 30 to 41 percent of the scanned images and averaged 36 percent; impervious surfaces covered an average of 64 percent. For the five low-density locations, open areas ranged from 68 to 82 percent of the scanned images and averaged 78 percent; impervious surfaces averaged 22 percent. Open areas consist of irrigated lawns and land that is either barren or covered by native vegetation. Because lawns were difficult to distinguish from open, barren land on the aerial photographs taken during winter months, the percent of irrigated lawns on high-density residential land was assumed to equal the area of lawns on the low-density residential land. Thus for low-density residential land, about 36 percent is irrigated lawns, about 42 percent is open land, and 22 percent is covered by impervious surfaces.

Using the above percentages, the area of land-use types was totaled for the floor of Eagle Valley (table 4). Open areas covered 6,600 acres, impervious surfaces covered 3,600 acres, lawns covered 2,400 acres, pastures covered 650 acres, and golf courses covered 320 acres.

The concentration of chloride in soil profiles above the water table has been used to estimate recharge by many workers (Allison and Hughes, 1978, 1983; Scanlon, 1991; Allison and others, 1994; Phillips, 1994; Prudic, 1994; Prych, 1998). The distribution of chloride in soil profiles is developed as small quantities of chloride are deposited onto land surface by precipitation (wet fall) and dust (dry fall), which move downward with infiltrating precipitation. As the water moves downward, some is lost to evapotranspiration and the remainder percolates to the water table as recharge. However, chloride is not taken up through the roots of most plants and becomes concentrated by evapotranspiration in the root zone (Allison and others, 1994, p. 8). Ideally (Wood, 1999, p. 3), the steady-state profile of chloride concentration with depth should show concentrations increasing gradually from land surface to a maximum concentration near a depth not affected by evapotranspiration. Beneath the point of maximum concentration and above the water table, chloride concentrations should have a relatively constant value that is related to the rate of recharge. Estimates made for this report also include recharge from water applied for irrigation.

The rate of recharge may be calculated from the chloride concentration in pore water above the water table, the chloride concentration of precipitation (including wet fall and dry fall), and the chloride concentration of irrigation water, using the equation modified from Allison and others $(1994$, p. 9):

$$
q_{w}=\left(C_{o} P\right)+\left(C_{i} I\right) / C_{p w},
$$

where $q_{w}$ is the recharge rate, in feet per year;

$C_{o}$ is chloride concentration of precipitation, in milligrams per liter;

$P$ is the rate of precipitation, in feet per year; $C_{i}$ is the chloride concentration of irrigation water, in milligrams per liter;

$I$ is the rate of irrigation, in feet per year; and $C_{p w}$ is average chloride concentration of pore water, in milligrams per liter.

Important assumptions made in application of equation 3 are that (1) land surface is neither aggrading nor degrading; (2) atmospheric deposition (wet fall plus dry fall) and chloride added to the soil from irrigation are the only sources of chloride and are constant through time; (3) the chloride moves with water (negligible dispersion) steadily and uniformly downward; and (4) and pore-water chloride concentrations are in equilibrium with the chloride flux at land surface.

The distribution of chloride in unsaturated sediments seldom is similar to that described above, causing uncertainties in applying the method to actual data. For example, precipitation is not constant through time as stated in assumption 2. In Carson City, about 70 percent of the annual precipitation generally falls from November through March and only about 10 percent falls from July through September (Owenby and Ezell, 1992, p. 15). Chloride from dry-fall deposition accumulates on land surface during the summer months and is incorporated into early winter precipitation. 
This, coupled with evapotranspiration during the summer, likely causes a spike in the chloride concentration as the accumulated chloride infiltrates. Seasonal changes in soil moisture were substantiated by neutronmoisture measurements made at the chloride profile sites. The measurements showed that soil moisture was depleted during summer months and increased following late fall and early winter precipitation. Such a process could produce multiple peaks in the chloride profile, followed by troughs of more dilute water that enters the profile later in winter and early spring. Multiple peaks also could be caused by geologic heterogeneities or macropores that allow faster percolation rates through a smaller part of the sediments (McCord and others, 1997, p. 1229; Wood, 1999, p. 2). Thus, estimates of recharge rates could vary depending on whether the samples were collected in areas where rates were greater than or less than the average rate. Results of numerical simulations suggest that unless many profiles are used, recharge estimates are accurate only within a factor of 3 or 4 (McCord and others, 1997, p. 1238).

For this study, chloride profiles were measured in areas where land use has been constant for at least 20 years and where land surface is stable; areas where surface runoff could alter the mass flux of chloride to the soil zone were avoided. Preferential flow through macropores, such as animal burrows, root tubes, and desiccation cracks, may permit more recharge than accounted for by the chloride mass balance method. However, in relatively flat, undisturbed landscape, such preferential flow is not considered to be a dominant recharge process (Phillips, 1994, p. 19).

Chloride profiles were collected at 16 sites (fig. 7). Ten sites are in open areas and six sites are in irrigated lawns or pastures. Sites 1 and 5 are outside the boundary of the valley floor, but were included to obtain data representative of open areas within the valley floor boundary but at a higher altitude. Chloride samples at site 4 were obtained prior to installation of the Silver Oaks golf course and are representative of conditions in open areas. Three of the irrigated sites $(8$, 9 , and 12) are in lawns irrigated by sprinklers with municipal water. Although site 9 is shown to be in an open area (fig. 7) the site actually is in a park (Mills Park). Two of the irrigated sites (7 and 10) are in pastures flood irrigated by diverting streamflow. Flood irrigation at site 7 is frequent and pasture grasses are cut annually, whereas at site 10 , flood irrigation is infrequent and used only to produce pasture grasses for grazing. Lastly, site 2 is in a golf course irrigated by sprinklers with treated wastewater effluent.

Chloride concentrations in the unsaturated zone were determined by collecting core samples and determining bulk density, moisture content, and chloride concentrations in the laboratory. To obtain soil samples at most sites, holes were advanced by driving thinwalled aluminum pipe ( 2 in. OD) to pre-determined depths for soil-core collection. Sediment cores (6 in. $x$ 1.25 in.) were then collected with a soil-core sampler and plastic retaining cylinder and immediately capped and sealed with plastic tape. One profile (site 15) was collected using a hollow-stem auger and split-spoon sediment sampler. Maximum depth of sampling was determined by saturated sediment or impenetrable material. Bulk density and volumetric moisture content of soil cores were determined gravimetrically at the USGS laboratory in Carson City, Nev. Chloride concentrations in core samples were then determined by the USGS National Research Program laboratory in Reston, Va. Three parts of deionized water were mixed with one part of sediment, by weight for each sample, and shaken occasionally during a 24-hour period. Chloride concentrations in the extracted water were determined using ion chromatography (Warren W. Wood, U.S. Geological Survey, written commun., 1994).

Although numerous chloride profiles would be ideal, the selected profiles in Eagle Valley provide a reasonable comparison between areas of different soil types and land use (figs. $8 A$ and $B$ ). Chloride profiles were generally consistent in open areas (fig. 8A, sites $1,4-6$, and 13-16) where the water table is deep. Peak concentrations ranged from 50 to $100 \mathrm{mg} / \mathrm{L}$, with most peaks less than $3 \mathrm{ft}$ in depth. Concentrations below $3 \mathrm{ft}$ were generally 20 to $50 \mathrm{mg} / \mathrm{L}$ and averaged about $30 \mathrm{mg} / \mathrm{L}$ at most sites.

For sites in saline soils, chloride concentrations were much greater where depth to water was 5 to $10 \mathrm{ft}$ or less (fig. 8B, sites 3,10 , and 11). Peak concentrations at these sites exceeded 1,000 mg/L. Even though site 10 is infrequently flood-irrigated, its peak is similar to the two sites in open areas. These sites are in soils described by Candland (1979) as saline-alkali affected and are coincident with the area of natural groundwater discharge (Worts and Malmberg, 1966, figs. 5 and 7). Within the area of ground-water discharge, the water table is sufficiently shallow that ground water is discharged by evaporation from bare soils, or by 


\section{A. SITES IN OPEN AREAS WITH NON-SALINE SOILS}
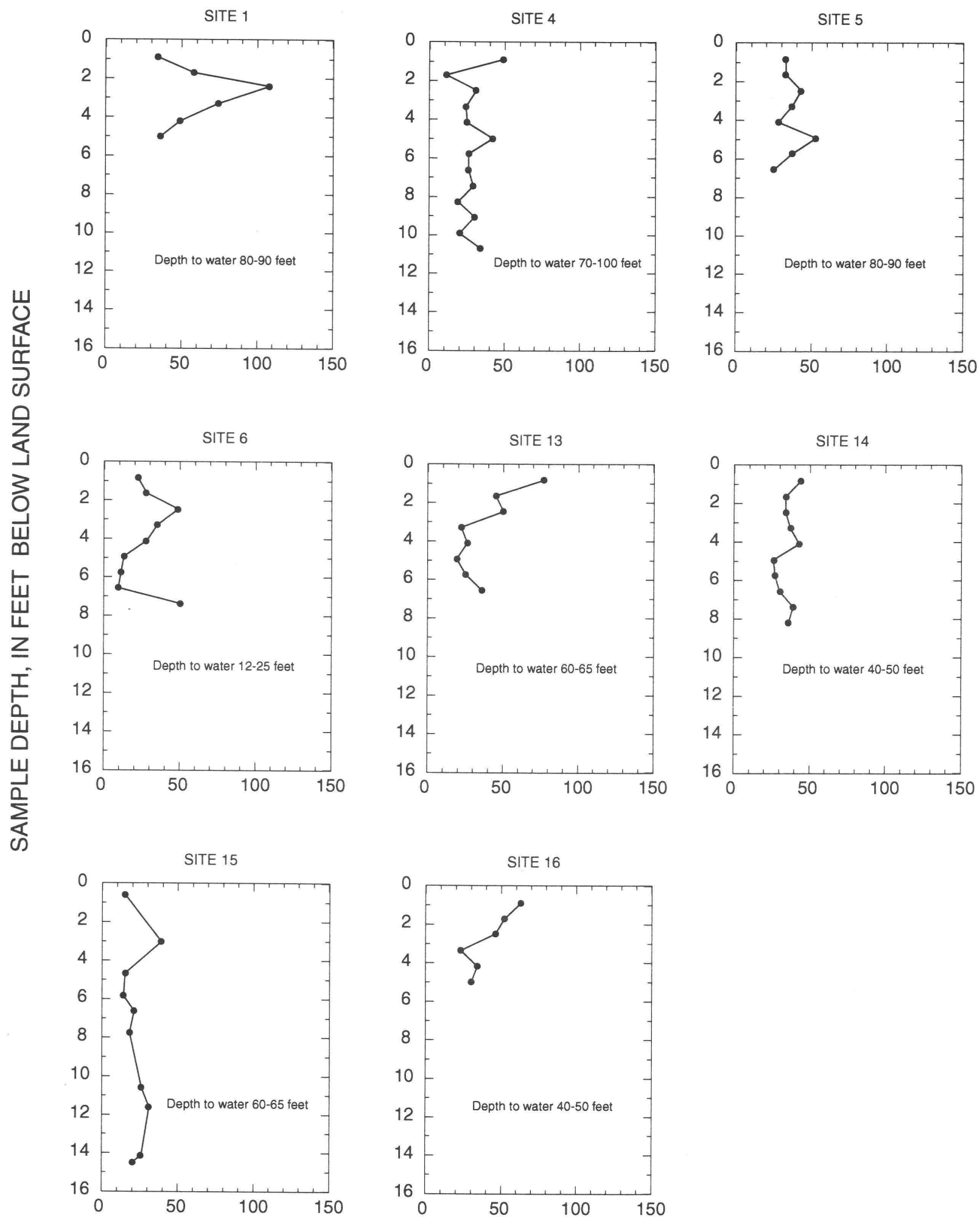

CHLORIDE CONCENTRATION IN PORE WATER, IN MILLIGRAMS PER LITER

Figure 8. Distribution of soil chloride at (A) sites in open areas with non-saline soils, and (B) sites in saline soils and irrigated areas, Eagle Valley, Nevada. Location of sites shown in figure 7. 


\section{B. SITES IN SALINE SOILS}
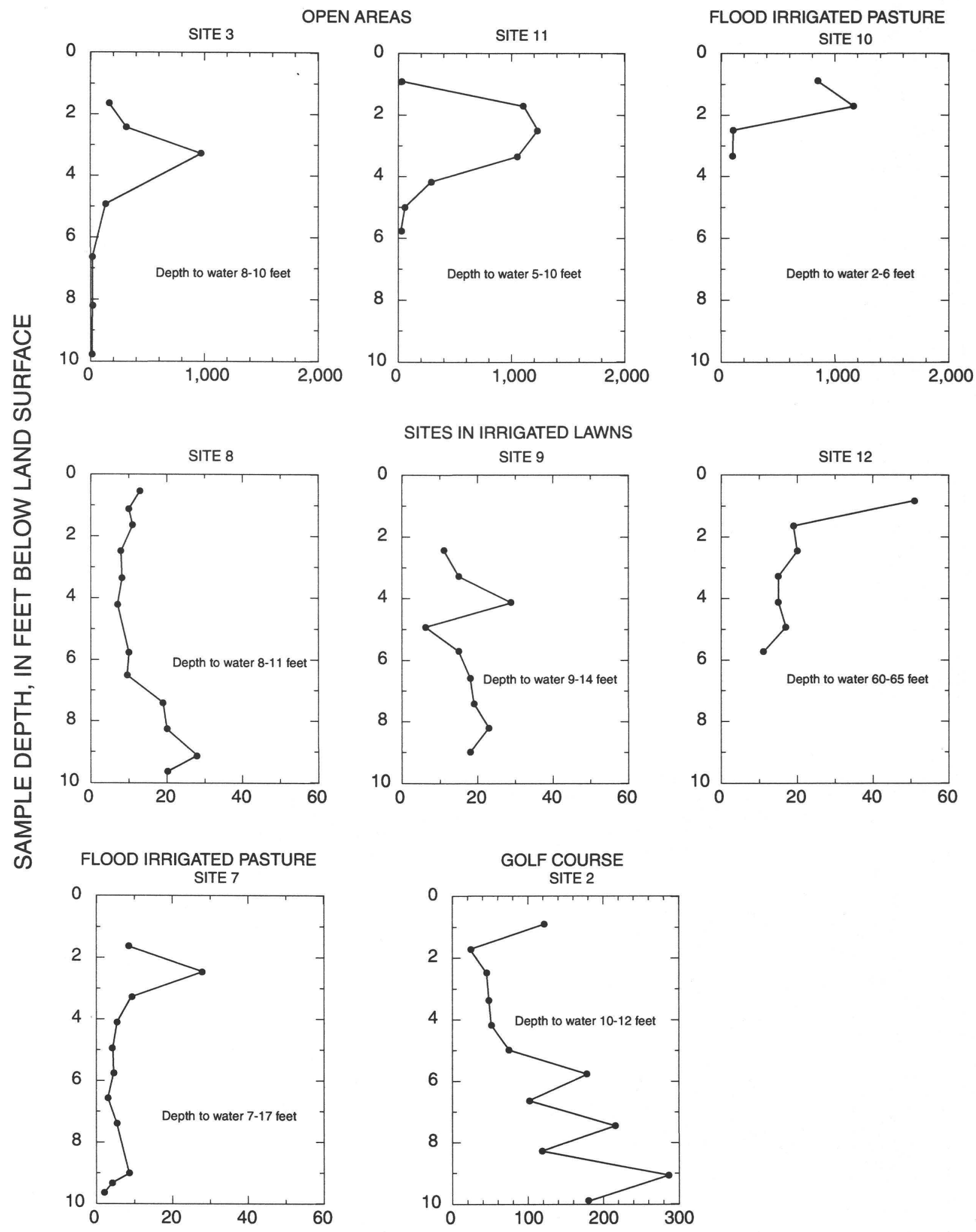

CHLORIDE CONCENTRATION IN PORE WATER, IN MILLIGRAMS PER LITER

Figure 8. Continued. 
transpiration of phreatophytes, and chloride likely accumulates in the capillary fringe to produce the high concentrations.

Chloride profiles in sediments beneath irrigated lawns (fig. 8B, sites 8, 9, and 12), have peak concentrations of $50 \mathrm{mg} / \mathrm{L}$ or less and most concentrations are between 10 and $20 \mathrm{mg} / \mathrm{L}$. The chloride profile beneath a heavily irrigated pasture (site 7) has a peak concentration of only $30 \mathrm{mg} / \mathrm{L}$ and most concentrations are less than $10 \mathrm{mg} / \mathrm{L}$. Finally, the chloride profile in a golf course irrigated with treated effluent (site 2), shows the greatest variability with concentrations ranging from 20 to $80 \mathrm{mg} / \mathrm{L}$ from 2 to $5 \mathrm{ft}$ in depth, and concentrations ranging from 100 to $300 \mathrm{mg} / \mathrm{L}$ from 5 to $10 \mathrm{ft}$ in depth. This variability could be caused by the relatively high chloride concentration in treated effluent applied during summer months followed by low concentrations in precipitation during winter months.

The high chloride concentrations in areas of saline soils (sites 3,10, and 11), suggest that recharge from precipitation and infrequent flood irrigation is minimal compared with ground-water discharge. When soils were mapped, much of the urban area of Carson City may have been over saline soils (Candland, 1979, p. 11) and these soils could not be completely mapped. The location of saline soils that were mapped by Candland (1979) coincides closely with areas of phreatophytes and depth to water of less than $5 \mathrm{ft}$, as shown by Worts and Malmberg (1966, figs. 5 and 7) in 1964. The extent of phreatophytes mapped in 1964 was used to approximate the boundary of saline soils where they were not mapped by Candland to produce the distribution shown by diagonal hachures in figure 7. Sites 7-9 are in areas that may have had saline soils, but presently do not. Accumulated salts in soils at these sites may have been flushed out by frequent irrigation. On the basis of the chloride profiles, no recharge was calculated for open areas or infrequently flooded pastures that coincide with saline soils, whereas, recharge was assumed beneath lawns and heavily irrigated pastures.

Estimates of the recharge rate at sites not in open areas with saline soils are summarized in table 5. Average precipitation on the valley floor of $10 \mathrm{in} / \mathrm{yr}$ was used for all locations except site 5, where Arteaga and Durbin (1979, p. 16) show an average precipitation of about $14 \mathrm{in} / \mathrm{yr}$. A value of $0.4 \mathrm{mg} / \mathrm{L}$ was used for the chloride concentration of precipitation. This value is an average obtained from 74 sampling sites in Nevada (Dettinger, 1989, p. 63) and from 24 sites near Reno, Nev. (Berger and others, 1997, p. 46). Rates at which water was applied for irrigation and the chloride concentration of irrigation water were obtained from records of the Carson City Utilities Department (Tom Hoffert, Kelvin Ikehara, Kyle Menath, written and oral communs., 1998) and from samples obtained for this study (Bostic and others, 1997, p. 507; Bonner and others, 1998, p. 518). Because of the uncertainties in application of the method discussed above, the range in recharge rates obtained for sites on open and irrigated areas was used to obtain a range in recharge on the valley floor beneath similar types of land use.

The amount of time for chloride to accumulate above a given depth may be estimated from the total mass of chloride measured in soils above that depth, divided by the average rate of chloride deposition at land surface. Using the values of $10 \mathrm{in}$. for average annual precipitation and $0.4 \mathrm{mg} / \mathrm{L}$ for the average chloride concentration, an average of 21 years is required to accumulate the amount of chloride measured in the uppermost $5 \mathrm{ft}$ of sediments at sites in open areas with non-saline soils. This indicates that using the 30 -year average for annual precipitation is reasonable in calculating an average recharge rate at these sites. A similar calculation for sites receiving irrigation water in addition to precipitation results in accumulation of the measured chloride in about 2 years. This suggests that in areas with saline soils, irrigation may quickly flush accumulated salts to the water table and that recharge rates during years of above-normal precipitation may be greater than that calculated using a long-term average precipitation.

Recharge rates for open areas range from 0.006 to $0.016 \mathrm{ft} / \mathrm{yr}$ (table 5). Applying this range to 5,500 acres with non-saline soils listed in table 4 results in a quantity ranging from about 30 to 90 acre-ft/yr (table 6). Using the long-term average precipitation of about 10 in. on the valley floor and the estimated rates of irrigation, recharge rates for irrigated lawns (sites 8, 9, and 12) range from 0.35 to $0.97 \mathrm{ft} / \mathrm{yr}$. This results in a quantity ranging from about 800 to 2,300 acre- $\mathrm{ft} / \mathrm{yr}$ for 2,400 acres of lawns (table 6). For 1995-98 when precipitation was 140 percent of normal, estimated recharge rates for irrigated lawns increased slightly, ranging from 0.40 to $0.98 \mathrm{ft} / \mathrm{yr}$ (table 5), which resulted in recharge of 960 to about 2,400 acre-ft/yr (table 6). A recharge rate of $1.9 \mathrm{ft} / \mathrm{yr}$ was obtained for the golf course irrigated with treated effluent (site 2 ), resulting in a volume of 600 acre-ft/yr from 320 acres of golf courses (table 6). 
Table 5. Chloride concentration of pore water, precipitation, and irrigation water; rates of precipitation and irrigation; and estimates of recharge rates from selected soil-chloride profiles

\begin{tabular}{|c|c|c|c|c|c|c|}
\hline \multirow{2}{*}{$\begin{array}{l}\text { Site number } \\
\text { (fig. 7) }\end{array}$} & \multicolumn{3}{|c|}{$\begin{array}{l}\text { Chloride concentration } \\
\text { (milligrams per liter) }\end{array}$} & \multirow{2}{*}{$\begin{array}{l}\text { Average annual } \\
\text { precipitation a } \\
\text { (feet) }\end{array}$} & \multirow{2}{*}{$\begin{array}{l}\text { Average } \\
\text { annual } \\
\text { Irrigation } \\
\text { (feet) }\end{array}$} & \multirow{2}{*}{$\begin{array}{c}\text { Average } \\
\text { annual } \\
\text { recharge rate } \\
\text { (feet) }\end{array}$} \\
\hline & Pore water ${ }^{c}$ & $\begin{array}{l}\text { Precip- } \\
\text { itation d }\end{array}$ & $\begin{array}{l}\text { Irrigation } \\
\text { water }\end{array}$ & & & \\
\hline \multicolumn{7}{|c|}{ Open areas } \\
\hline 1 & 57 & 0.4 & -- & 0.83 & -- & 0.006 \\
\hline 4 & 29 & .4 & -- & .83 & -- & .011 \\
\hline 5 & 29 & .4 & -- & 1.2 & -- & .016 \\
\hline 6 & 27 & .4 & -- & .83 & -- & .013 \\
\hline 13 & 39 & .4 & -- & .83 & -- & .012 \\
\hline 14 & 35 & .4 & -- & .83 & -- & .010 \\
\hline 15 & 25 & .4 & -- & .83 & -- & .013 \\
\hline 16 & 43 & .4 & -- & .83 & -- & .009 \\
\hline \multicolumn{7}{|c|}{ Irrigated lawns or pasture } \\
\hline $2^{\mathrm{e}}$ & 120 & .4 & 65 & $.83(1.16)$ & 3.4 & $1.9(1.9)$ \\
\hline $7^{\mathrm{f}}$ & 7.8 & .4 & .34 & $.83(1.16)$ & $2.3-9.0$ & $.14-.43(.16-.45)$ \\
\hline $8^{\mathrm{g}}$ & 13 & .4 & 3.5 & $.83(1.16)$ & 3.5 & $.97(.98)$ \\
\hline $9^{\mathrm{g}}$ & 15 & .4 & 3.5 & $.83(1.16)$ & 2.0 & $.49(.50)$ \\
\hline $12^{\mathrm{h}}$ & 23 & .4 & 3.5 & $.83(1.16)$ & 2.5 & $.35(.40)$ \\
\hline
\end{tabular}

${ }^{\text {a }}$ From precipitation map by Arteaga and Durbin (1979, p. 16); average precipitation on floor of Eagle Valley is 10 in. $(0.83 \mathrm{ft})$; at site 5 , average is 14 in. ( $1.2 \mathrm{ft})$. Value in parentheses is average precipitation during 1995-98 (140 percent of normal).

${ }^{\mathrm{b}}$ Recharge rate is calculated from equation 3 in text. Equals chloride concentration of precipitation times rate of precipitation, plus chloride concentration of irrigation water times rate of irrigation, divided by chloride concentration of pore water. Values in parentheses from average precipitation during 1995-98.

${ }^{\mathrm{c}}$ Average chloride concentration in profile.

${ }^{d}$ From Dettinger (1989, p. 63) and Berger and others (1997, p. 46).

${ }^{e}$ Golf course irrigated with treated effluent. Chloride concentration of effluent is average of 13 samples taken during 1988-98 (Kelvin Ikehara, Carson City Utilities Department, oral commun., 1998). Irrigation rate is average annual use at Eagle Valley Golf Course, 700 acre-ft/yr during 1994-98 (Kyle Menath, Carson City Utilities Department, written commun., 1998), divided by area of golf course, 206 acres.

${ }^{\mathrm{f}}$ Pasture irrigated with diverted streamflow from Ash Canyon Creek. Chloride concentration of irrigation water is average concentration of streamflow during summer months of 1996-97 (Bostic and others, 1997, p. 507; Bonner and others 1998, p. 518). Range for irrigation rates determined from single measurement of loss on field, $2.3 \mathrm{ft}$ measured July 31, 1998, and from maximum rate allowed by Alpine Decree, $9 \mathrm{ft}$ (U.S. District Court, Nevada,1980, p. 3).

g Chloride concentration of lawn-irrigation water is average concentration of municipal supply based on 35 samples taken from 27 points of delivery during 1981-97 (Tom Hoffert, Carson City Utilities Department, written commun., 1998). Irrigation rate determined from April through November 1998 (Scott Fahrenbruch, Carson City Parks and Recreation Department, written commun., 1998).

${ }^{\mathrm{h}}$ Chloride concentration of lawn irrigation water is average concentration of municipal supply based on 35 samples taken from 27 points of delivery during 1981-97 (Tom Hoffert, Carson City Utilities Department, written commun., 1998). Irrigation rate based on difference between summer and winter water use for Carson City, 1994-97 (Tom Hoffert, Carson City Utilities Department, written commun., 1998), 5,300 acre-ft; divided by total area of lawns, 2,400 acres (table 4). 
Table 6. Summary of estimated recharge from infiltration of precipitation and water applied for irrigation on floor of Eagle Valley

\begin{tabular}{|c|c|c|c|}
\hline Source & $\begin{array}{l}\text { Area }^{\text {a }} \\
\text { (acres) }\end{array}$ & $\begin{array}{l}\text { Recharge rate } \\
\text { (feet per year) }\end{array}$ & $\begin{array}{c}\text { Recharge } \\
\text { (acre-feet per year) }\end{array}$ \\
\hline $\begin{array}{l}\text { Precipitation on open areas } \\
\quad \text { (non-saline soils) }\end{array}$ & 5,500 & $0.006-0.016$ & $30-90$ \\
\hline Irrigation of lawns & 2,400 & $\begin{array}{c}0.35-0.97 \\
(0.40-0.98)^{c}\end{array}$ & $\begin{array}{c}800-2,300 \\
(960-2,400)^{c}\end{array}$ \\
\hline Irrigation of golf courses & 320 & 1.9 & 600 \\
\hline
\end{tabular}

For irrigated pasture (site 7), a range in irrigation rate was used that was based on a single measurement of irrigation rate for the field on July 31,1998 , and on application rates of 6 to $9 \mathrm{ft} / \mathrm{yr}$ allowed by the Alpine Decree (U.S. District Court, Nevada, 1980, p. 3). Measurement of the actual application rate for the field was difficult as inflow to and outflow from the field was spread over diffuse areas and could not be measured. For this site, a range in recharge rates from 0.14 to $0.43 \mathrm{ft} / \mathrm{yr}$ was calculated assuming long-term average annual precipitation, and a range from 0.16 to 0.45 was calculated assuming average precipitation for 1995-98. Applying the ranges to 220 acres of heavily irrigated pasture, recharge of 30-95 acre-ft/yr was estimated using long-term average precipitation and from about 40-100 acre-ft/yr using average precipitation during 1995-98. These volumes are lower than those estimated from stream losses (1,000 to 1,700 acre-ft/yr) from Kings Canyon and Ash Canyon Creeks (see section titled "Infiltration of Streamflow"). The stream losses, however, include losses from stream channels and irrigation ditches. For this reason, the volume determined from streamflow measurements was used for the estimate of recharge from heavily irrigated pastures.

\section{WATER BUDGETS}

Two water budgets were developed for the floor of Eagle Valley using compiled data and estimates of water-budget components presented in this report. Both budgets are for the area of the valley floor overlying the basin-fill aquifer (fig. 4). The first budget is an overall water budget of all water entering or leaving the valley floor. The second budget is a ground-water budget for all sources of recharge and inflow to, or discharge and outflow from the basin-fill aquifer underlying the valley floor.
Much of the data used for estimates of waterbudget components were collected during the relatively wet years of 1995-98. During the calendar years 199598, annual precipitation recorded on the floor of Eagle Valley averaged 15.28 in. (National Climate Center, 1996-98, Gary Barbato, National Weather Service, oral commun., 1999), about 140 percent of the normal 10.87 in. for 1961-90. During 1995-98, streamflow from the surrounding mountains increased, and water levels near the mouths of watersheds tributary to Eagle Valley rose, increasing the amount of subsurface inflow. For these reasons, water budgets are presented for the 1995-98 period, along with estimated average conditions for comparison.

In the following sections, estimates of average flow for gaged streams have been adjusted to a common, long-term period of record based on the recorded streamflow of the West Fork Carson River at Woodfords, Calif. (period of record October 1900 to May 1907, 1910-11, and October 1938 through September 1998). Long-term average flow for each stream was calculated by multiplying the average flow for the period of record by the ratio of (1) the long-term average flow of the West Fork Carson River to (2) average flow of West Fork Carson River during the same period, as described previously. The ratios were 0.92 for Eagle Valley creek (period of record unaffected by treated effluent, 1988-98) and Clear Creek (period of record 1949-62 and 1990-98), 0.99 for Kings Canyon and Ash Canyon Creeks (periods of record 1977-98), and 1.002 for North Kings Canyon diversion (period of record 1990-98). Most ratios were nearly one, as the wet years of 1995-98 offset the effect of the drought during 1987-94. 


\section{Overall Water Budget}

Sources of inflow for the overall water budget are streamflow and subsurface inflow from the surrounding mountains, precipitation on the valley floor, water imported from the Dayton and Carson Valley Hydrographic Areas and from Marlette-Hobart Lakes, and treated effluent imported from Brunswick reservoir for irrigation of the Silver Oaks golf course (table 7). Outflow consists of surface-water and subsurface outflow leaving the valley floor, treated effluent exported to Brunswick reservoir, and water discharged to the atmosphere by evapotranspiration. Discharge by evapotranspiration was not directly measured in this study; instead, it was estimated from the difference between inflow and outflow and from independent estimates of evapotranspiration rates. Water imported from outside Eagle Valley and the water imported to and exported from Brunswick reservoir are not directly related to the amount of annual precipitation, but depend on current water-management practices. For this reason, volumes estimated for these sources for 1995-98 also are used for average conditions.

Maurer and Berger (1997, p. 33) estimated average annual streamflow from the mountains surrounding Eagle Valley to be 8,700 acre-ft/yr on the basis of available records to 1995 and adjusted to the long-term record of the West Fork Carson River at Woodfords, Calif., as of 1995 . The 8,700 acre-ft/yr include 7,800 acre-ft/yr from the perennial streams draining Clear Creek, Kings Canyon, and Ash Canyon watersheds, and $900 \mathrm{acre}-\mathrm{ft} / \mathrm{yr}$ from ephemeral streams draining the remaining watersheds. Streamflow from watersheds having perennial streams was directly measured using continuous-recording gaging stations. The remaining ephemeral streamflow was estimated using a method developed by Moore (1968, p. 33), which, when applied to gaged watersheds, provided a reasonable estimate of average annual streamflow (Maurer and Berger, 1997, p. 32).

As described in the section titled "Infiltration of Streamflow," the combined gaged flow of perennial streams draining the Clear Creek, Kings Canyon, and Ash Canyon watersheds was 13,000 acre- $\mathrm{ft} / \mathrm{yr}$ for 1995-98, about 140 percent of the long-term average (9,000 acre-ft/yr). Ephemeral streamflow gaged at Vicee Canyon was 47 acre-ft during 1994 (Clary and others, 1995, p. 212) and was 134 acre-ft/yr during 1996 (Bostic and others, 1997, p. 174); an increase of 285 percent. For comparison, flow of Ash Canyon increased from 646 acre-ft in 1994 (Clary and others, 1995, p. 211) to 1,967 acre-ft in 1996 (Bostic and others, 1997, p. 173); an increase of 300 percent. This suggests that ephemeral streamflow varies similarly to perennial streamflow. Assuming that the flow of all ephemeral streams increased during 1995-98, ephemeral streamflow was 140 percent of the average 900 acre-ft/yr, or about 1,300 acre-ft/yr. Thus, the annual quantity of streamflow entering the floor of Eagle Valley during 1995-98 was about 14,000 acre-ft/yr, and average streamflow is about 9,900 acre-ft/yr (table 7).

For comparison, during the last years of an extended drought (1990-94), average flow of the perennial streams was 4,000 acre-ft/yr, as calculated from data published by the U.S. Geological Survey (199195), or about 40 percent of average. Assuming that ephemeral streamflow decreased by the same amount, ephemeral flow was about 400 acre-ft/yr during 199094, and total streamflow into Eagle Valley was only about 4,400 acre-ft/yr. Thus, from 1990-94 to 1995-98, the total annual streamflow into Eagle Valley also varied by more than 300 percent.

Water imported from the Marlette-Hobart water system is metered by the State of Nevada, and water imported from the Dayton Valley and Carson Valley Hydrographic Areas along with inflow and outflow of treated sewage effluent is metered by Carson City Utilities Department. During 1995-98, the average quantities imported were 3,400 acre-ft/yr from Dayton and Carson Valleys and 1,100 acre-ft/yr from the MarletteHobart system (Tom Hoffert, Carson City Utilities Department, written communs., 1997-99). About 400 acre- $\mathrm{ft} / \mathrm{yr}$ of treated effluent was applied for irrigation of Silver Oaks golf course in 1998 (Kyle Menath, Carson City Utilities Department, written commun., 1999). During summer months, Silver Oaks golf course is supplied largely by effluent imported from Brunswick reservoir (Kelvin Ikehara, Carson City Utilities Department, oral commun., 1999). For purposes of the overall water budget, all $400 \mathrm{acre}-\mathrm{ft} / \mathrm{yr}$ was estimated as imported from the reservoir (table 7).

Subsurface inflow entering the floor of Eagle Valley was previously estimated to range from 3,200 to 4,400 acre-ft/yr (Maurer and Berger, 1997, p. 33 and 34). These estimates are based on data collected from test holes drilled near the base of the mountains where eight watersheds enter the floor of Eagle Valley. The eight instrumented watersheds represent about 70 percent of the mountain block area. Estimates for the remainder of the watersheds were made using the range 
Table 7. Overall water budget for floor of Eagle Valley, 1995-98 and average conditions

[All values in acre-feet per year (acre-ft/yr), rounded to two significant figures. Discharge by evapotranspiration and changes in ground-water storage are represented by difference between inflow and outflow]

\begin{tabular}{|c|c|c|c|c|c|}
\hline \multicolumn{3}{|l|}{ INFLOW } & \multicolumn{3}{|l|}{ OUTFLOW } \\
\hline & $1995-98$ & Average $^{a}$ & & 1995-98 & Average $^{a}$ \\
\hline \multicolumn{6}{|c|}{ Surface Water } \\
\hline Mountain block & $14,000^{\mathrm{b}}$ & $9,900^{\mathrm{c}}$ & Clear Creek & $6,100^{d}$ & $3,500^{\mathrm{e}}$ \\
\hline $\begin{array}{l}\text { Imports from: } \\
\text { Dayton and Carson Valleys }\end{array}$ & $3,400^{\mathrm{f}}$ & 3,400 & Eagle Valley creek & $4,300^{g}$ & $2,100^{h}$ \\
\hline Marlette-Hobart Lakes & $1,100^{i}$ & 1,100 & Treated effluent to Brunswick reservoir & $3,700^{j}$ & 3,700 \\
\hline Treated effluent on golf courses & $400^{\mathrm{k}}$ & 400 & Unnamed creeks & $340^{1}$ & $250^{\mathrm{m}}$ \\
\hline Subtotal & 19,000 & 15,000 & Subtotal & 14,000 & 9,600 \\
\hline \multicolumn{6}{|c|}{ Subsurface Flow } \\
\hline \multirow[t]{5}{*}{ Mountain block } & $4,600^{\mathrm{n}}$ & $3,800^{\circ}$ & To Dayton Valley & $2,200^{p}$ & 2,200 \\
\hline & & & $\begin{array}{l}\text { To Carson Valley: } \\
\text { beneath Clear Creek } \\
\text { beneath upper part of Clear Creek watershed }\end{array}$ & $\begin{array}{r}400^{q} \\
2,500^{r}\end{array}$ & $\begin{array}{r}400 \\
2,500\end{array}$ \\
\hline & & & Subtotal & 5,100 & 5,100 \\
\hline & \multicolumn{3}{|c|}{ Precipitation on Valley Floor } & & \\
\hline & $16,000^{s}$ & $12,000^{\mathrm{t}}$ & \multirow{3}{*}{ TOTAL (rounded) } & & \\
\hline TOTAL (rounded) & 40,000 & 31,000 & & 19,000 & 15,000 \\
\hline INFLOW MINUS OUTFLOW & 21,000 & 16,000 & & & \\
\hline
\end{tabular}

a Average flow of perennial streams adjusted to long-term average of West Fork Carson River at Woodfords, Calif. (period of record October 1900 to May 1907, 1910-11, and October 1938 through September 1998) by multiplying average flow for period of record at each gage reported by Preissler and others (1999) by ratio of (1) long-term average annual flow of West Fork Carson River to (2) average annual flow of West Fork Carson River at Woodfords during period of record at each gage. Volumes of imported and exported water and subsurface outflow for average conditions are assumed equal to 1995 98 rates, except where noted otherwise.

${ }^{\mathrm{b}}$ Includes average flow of perennial streams, 1995-98 (13,000 acre-ft/yr), calculated from data published by U.S. Geological Survey (1996-99), plus 140 percent of average ephemeral streamflow of $900 \mathrm{acre}-\mathrm{ft} / \mathrm{yr}(1,300 \mathrm{acre}-\mathrm{ft} / \mathrm{yr})$.

c Includes average flow of perennial streams totaling 9,000 acre-ft/yr, plus average ephemeral streamflow of 900 acre-ft/yr from Maurer and Berger (1997, p. 33).

${ }^{\mathrm{d}}$ Estimated from flow at gage, 1995-98, and relation shown in figure 5.

e Estimated from average flow at gage and relation shown in figure 5.

${ }^{\mathrm{r}}$ Includes 1,600 acre-ft/yr of ground-water pumped in Dayton Valley and Carson Valley Hydrographic Areas, and 1,800 acre-ft/yr of Carson River water pumped from induction wells in the Dayton Valley Hydrographic Area. Both values averaged for 1995-98.

g Average flow at gage, 1995-98, calculated from data published by U.S. Geological Survey (1996-99).

${ }^{\mathrm{h}}$ Average flow at gage, 1988-98, calculated from data published by U.S. Geological Survey (1989-99) adjusted to long-term average of West Fork Carson River at Woodfords, Calif.

i Imported from Lake Tahoe and Washoe Valley Hydrographic Areas (Tom Hoffert, Carson City Utilities Department, written commun., 1997); average for 1995-98.

${ }^{j}$ Exported to Dayton Valley Hydrographic Area (Kyle Menath, Carson City Utilities Department, written commun., 1999); average for 1995-98.

k Imported from Brunswick Reservoir in Dayton Valley Hydrographic Area (Kyle Menath, Carson City Utilities Department, written commun., 1998); 400 acre-ft/yr to Silver Oaks Golf Course in 1998.

${ }^{1}$ Estimated from relation shown in figure 10, using flow of Eagle Valley Creek, 1995-98.

${ }^{\mathrm{m}}$ Estimated from relation shown in figure 10, using average flow of Eagle Valley Creek adjusted to long-term average of West Fork Carson River at Woodfords, Calif.

${ }^{\mathrm{n}}$ Twenty percent greater than average 3,800 acre-ft/yr from range of 3,200-4,400 acre-ft/yr estimated by Maurer and Berger (1997, p. 33).

${ }^{\circ}$ Average from range of 3,200-4,400 acre-ft/yr estimated by Maurer and Berger (1997, p. 33).

${ }^{\mathrm{p}}$ From Maurer (1997, p. 31).

${ }^{\mathrm{q}}$ Estimated using Darcy’s Law.

${ }^{\mathrm{r}}$ Estimated from deficit of water yield from Clear Creek, about 3 in. over the 9,880 acres of watershed (Maurer and Berger, 1997, fig. 11 a and table 9).

${ }^{s}$ Estimated as 140 percent of average 11,500 acre-ft/yr reported by Maurer and Berger (1997, p. 33).

${ }^{t}$ From Maurer and Berger (1997, p. 33) estimate of 11,500 acre-ft/yr using map of Arteaga and Durbin (1979, p. 16), rounded to 12,000 acre-ft /yr. 
of subsurface inflow obtained for adjacent instrumented watersheds with similar geology. Using the average of the range in estimates, subsurface inflow from the surrounding mountains is about 3,800 acre$\mathrm{ft} / \mathrm{yr}$.

Since the estimates of subsurface inflow were made in 1994 and 1996, water levels near the mouths of most of the instrumented watersheds have risen about $10 \mathrm{ft}$ at sites 1, 3, 6, 8, and 13; and about $30 \mathrm{ft}$ at site 10 (fig. 9). Water levels in wells drilled in 1994 rose during 1995, with greater rises at some wells (sites 8 and 10) and lesser rises at others (site 6). Water levels in all wells rose rapidly following flooding in January 1997, with some showing declines during 1998 (sites 1, 3 , and 6). Water levels in wells near Clear Creek (site 17, figs. 4 and 9) rose only about $1 \mathrm{ft}$ during 1996-98, but showed seasonal fluctuations.

The rise in water levels near the mouths of most of the instrumented watersheds increased the saturated cross-sectional area of basin-fill sediments through which subsurface inflow takes place. Using water levels measured in 1998, estimates of the saturated cross-sectional area at Kings Canyon, Ash Canyon, and Vicee Canyon increased by 10 to 20 percent compared with that estimated in 1994 by Maurer and others (1996, p. 30), while the saturated cross-sectional area at the other five instrumented watersheds increased from 11 to 28 percent compared with that estimated in 1996 by Maurer and Berger (1997, p. 18 and 19). Overall, saturated cross-sectional areas in the instrumented watersheds increased by an average of about 20 percent, however, the hydraulic gradients were approximately the same. The previous estimates of subsurface inflow were made using Darcy's Law, which states that flow is proportional to the saturated cross-sectional area through which flow takes place. Thus, subsurface inflow from the instrumented watersheds also increased by about 20 percent. Assuming that this average is applicable to all watersheds tributary to Eagle Valley, subsurface inflow for 1995-98 was about 20 percent greater than the average 3,800 acre-ft/yr estimated by Maurer and Berger (1997, p. 33), or about $4,600 \mathrm{acre}-\mathrm{ft} / \mathrm{yr}$ (table 7). The 3,800 acre-ft/yr of subsurface inflow estimated by Maurer and Berger (1997, p. 33) is probably representative of average to dry conditions (table 7).

The relatively small increase ( 20 percent) in estimates of subsurface inflow from the end of extended drought to above-normal precipitation shows that subsurface inflow to the valley floor is relatively constant over time compared to the large variation in streamflow from the mountains. Using the estimates above, total inflow from the mountains, including streamflow and subsurface inflow, varied from about 8,200 acre-ft/yr during dry conditions, to 13,700 acre-ft/yr during average conditions, to 18,900 acre- $\mathrm{ft} / \mathrm{yr}$ during wet conditions.

Using the map by Arteaga and Durbin (1979, p. 16) annual precipitation on the valley floor was estimated to be $11,500 \mathrm{acre}-\mathrm{ft} / \mathrm{yr}$, rounded to 12,000 acre-ft/yr on table 7 (Maurer and Berger, 1997, p. 33). During the wet years of 1995-98, annual precipitation increased by about 140 percent, as discussed previously in this section. Assuming precipitation increased equally over the valley floor, precipitation for 1995-98 totaled about 16,000 acre-ft/yr (table 7).

The total inflow to the floor of Eagle Valley during 1995-98 was about 40,000 (table 7). During average conditions, total inflow is about 31,000 acre-ft/yr.

During 1995-98, streamflow out of the valley floor from Clear Creek, Eagle Valley creek, unnamed creeks north of Eagle Valley creek, and effluent exported to Brunswick reservoir, were estimated to total about 14,000 acre-ft/yr (table 7). During average conditions, outflow from these sources is about 9,600 acre-ft/yr.

In the section titled "Infiltration of Streamflow," outflow from Clear Creek was estimated to be 6,100 acre-ft/yr during 1995-98, and 3,500 acre-ft/yr during average conditions. Outflow in Eagle Valley creek is gaged (site 18, fig. 4), with an average flow during 1995-98 of 4,300 acre-ft/yr calculated from data published by the U.S. Geological Survey (1996-99). For years of record at the gage, excluding 1985-87 when flow in Eagle Valley creek included treated effluent, average flow calculated from data published by the U.S. Geological Survey (1988-99) and adjusted to the long-term record of West Fork Carson River at Woodfords, Calif., is 2,100 acre-ft/yr.

Total outflow of the unnamed creeks north of Eagle Valley creek (sites 19 and 20, fig. 4) was approximated from two streamflow measurements compared with gaged flow of Eagle Valley creek at the same date and time (fig. 10). Assuming that the relation between instantaneous flows at both sites is similar to average annual flow as suggested by Riggs (1969), the average annual flow of Eagle Valley creek for $1995-98,4,300$ acre- $\mathrm{ft} / \mathrm{yr}\left(6.0 \mathrm{ft}^{3} / \mathrm{s}\right)$ corresponds to a flow of $0.47 \mathrm{ft}^{3} / \mathrm{s}$, or about 340 acre-ft/yr (table 7) for the unnamed creeks for 1995-98. Similarly, flow for average conditions can 

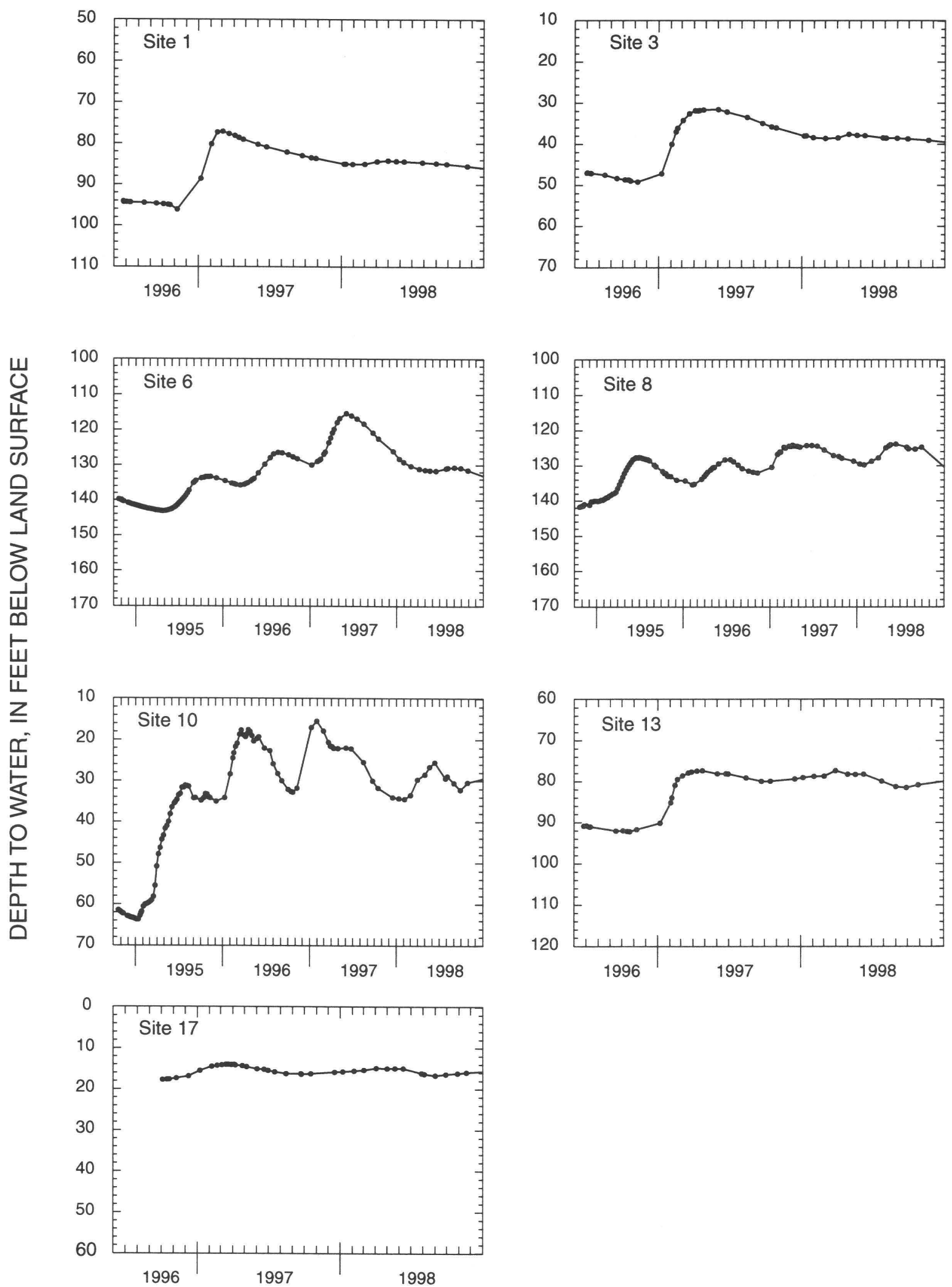

Figure 9. Changes in water levels at wells near the mouths of selected watersheds tributary to Eagle Valley, Nevada, 1994-98. Locations of sites shown in figure 4. 
be estimated from figure 10 . The average annual flow for 1988-98 of 2,100 acre-ft/yr $\left(2.91 \mathrm{ft}^{3} / \mathrm{s}\right)$ for Eagle Valley creek corresponds to flow of $0.35 \mathrm{ft}^{3} / \mathrm{s}$, or 250 acre-ft/yr (table 7). Exportation of treated effluent to Brunswick reservoir averaged 3,700 acre-ft/yr for 1995-98 (table 7; Kyle Menath, Carson City Utilities Department, Wastewater Reclamation Plant, written commun., 1999).

Subsurface outflow from the hydrographic area beneath the valley floor has been reported eastward toward the Dayton Valley Hydrographic Area north of Prison Hill, and southeastward toward the Carson Valley Hydrographic Area beneath Clear Creek (Worts and Malmberg, 1966, p. 11; Arteaga, 1986, p. 8; Maurer, 1997, p. 31). Water-level rises on the valley floor during the wet years of 1995-98 were generally about 5-10 ft (fig. 3). Because this amount is a small proportion of the total saturated thickness of basin-fill aquifers in areas of subsurface outflow, changes in subsurface outflow from wet years to average or dry conditions are probably minimal and the same quantities were used for water budget estimates for 1995-98 and average conditions.

Previous estimates of subsurface outflow to the Dayton Valley Hydrographic Area north of Prison Hill ranged from 700 acre-ft/yr (Arteaga, 1986, p. 31) to

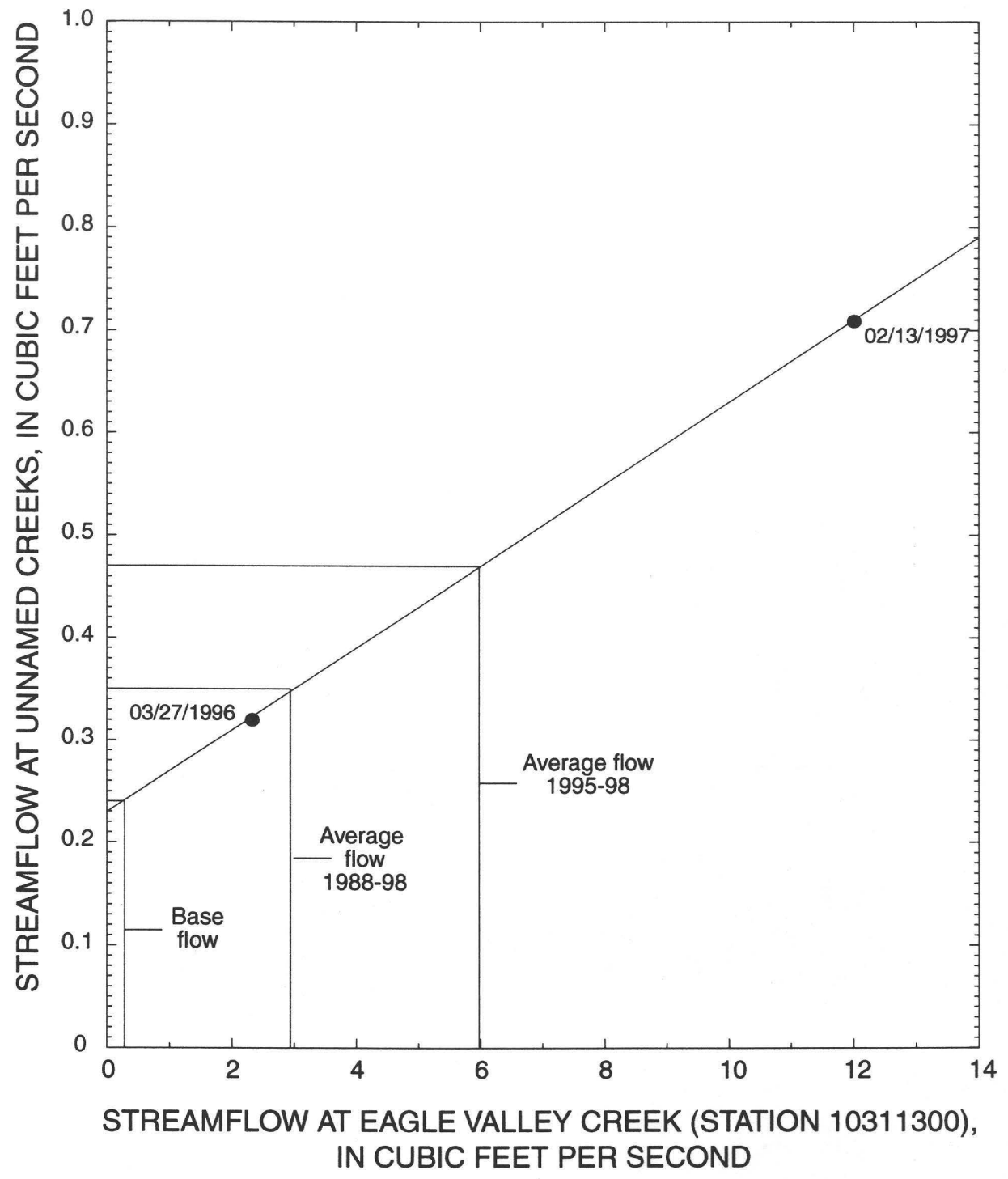

Figure 10. Relation between streamflow of Eagle Valley creek near Carson City (site 18, fig. 4) and total streamflow of unnamed creeks north of Eagle Valley creek, Eagle Valley, Nevada (sites 19 and 20, fig. 4). Average flow for 1995-98, average flow for 1988-98 adjusted to long-term, and base flows are shown. 
2,200 acre-ft/yr (Maurer, 1997, p. 31). The lower estimate was based on a numerical ground-water flow model of Eagle Valley, whereas the higher estimate was determined from measured hydraulic gradients and hydrogeologic data from six deep wells. The quantity of 2,200 acre-ft/yr was used because it incorporated the most current information.

Previous estimates of subsurface outflow to the Carson Valley Hydrographic Area beneath Clear Creek ranged from 600 acre-ft/yr (Worts and Malmberg, 1966, p. 29) to 1,200 acre-ft/yr (Arteaga and Durbin, 1979, p. 32). Since these estimates were made, deep wells have been drilled near the hydrographic-area boundary near Clear Creek that provide data for a refined estimate of the subsurface outflow.

Lithologic and hydrologic data from the wells and measurement of the hydraulic gradient during this study were used with Darcy's Law to estimate subsurface flow beneath Clear Creek. Darcy's Law as modified from Heath (1989, p. 12) can be expressed as:

$$
Q=0.0084 K A(d h / d l),
$$

where $Q$ is the quantity of ground-water flow, in acrefeet per year;

$K$ is hydraulic conductivity, in feet per day;

$A$ is the cross-sectional area through which flow occurs, perpendicular to the direction of flow, in square feet;

$(d h / d l)$ is the hydraulic gradient in foot per foot; and 0.0084 is the factor to convert cubic feet per day to acre-feet per year.

Water-level measurements from three wells near the hydrographic-area boundary, Shultz, Stewart \#1, and Prison wells, show that the hydraulic gradient is about 115 degrees from true north, parallel to Clear Creek, at $0.012 \mathrm{ft} / \mathrm{ft}$ (fig. 11A). This ground-water flow direction is similar to that determined by Worts and Malmberg (1966, fig. 4), who show water-level contours perpendicular to Clear Creek in 1964.

A cross section perpendicular to ground-water flow direction was developed using mapped exposures of granitic bedrock and lithologic descriptions from drillers' logs (fig. 11B). Exposures of granitic bedrock were mapped by the authors northeast and southwest of Clear Creek (fig. 11A). The exposure northeast of Clear Creek is near the southern end of the mapped location of Indiano Variant and Prey soils (Candland, 1979, sheets 2 and 4). Indiano Variant soils are characterized by bedrock at depths of 29 in. (Candland, 1979, p. 25), and the bedrock outcrop is within the mapped extent of
Prey soils. Because a detailed geologic map for that area is not available, the mapped extent of Indiano Variant and Prey soils was used to approximate the location of near-surface consolidated rocks northeast of Clear Creek (fig. 11A). A detailed geologic map by Pease (1980) does not include granitic bedrock exposures mapped southwest of Clear Creek. However, the exposures were recognized by Worts and Malmberg (1966, fig. 4) who mapped consolidated rocks southwest of Clear Creek. Their map of granitic bedrock was used for figure $11 \mathrm{~A}$.

Lithologic descriptions from drillers' logs show that the depth to granitic bedrock is about $250 \mathrm{ft}$ below land surface near Stewart \#3 well, $280 \mathrm{ft}$ near Speedway \#3 well, and $513 \mathrm{ft}$ at the Schultz well (fig. 11B; Nevada drillers' log numbers 10351, 47199, and 37781 , respectively). Descriptions of the granitic rocks in the drillers' logs suggest that they are solid, granitic bedrock and ground-water flow through them is probably minimal. The area of saturated basin-fill sediments beneath the cross section was estimated to be $1,296,000 \mathrm{ft}^{2}$.

The hydraulic conductivity and transmissivity of basin-fill sediments near the cross section have been estimated by Arteaga (1986) and Johnson and others (1996). Values of hydraulic conductivity reported near the cross section by Arteaga (1986, p. 29) ranged from 0.4 to $5.2 \mathrm{ft} / \mathrm{d}$. Transmissivities of $3,400,3,600$, and $9,200 \mathrm{gal} / \mathrm{d} / \mathrm{ft}$ for three wells near the cross section were reported by Johnson and others (1996, p. 3-26). Transforming the values to units of square feet per day and dividing by the perforated interval of the wells, results in hydraulic conductivities of 3.2, 3.0, and 3.2 $\mathrm{ft} / \mathrm{d}$, respectively. Using the hydraulic gradient of 0.012 $\mathrm{ft} / \mathrm{ft}$, an area of $1,296,000 \mathrm{ft}^{2}$, hydraulic conductivity of $3 \mathrm{ft} / \mathrm{d}$, and equation 1 , subsurface outflow through the cross section is about 400 acre- $\mathrm{ft} / \mathrm{yr}$ (table 7).

In addition, ground water may flow out of the hydrographic area across the southern boundary of the Clear Creek watershed. Maurer and Berger (1997, p.

34) note that water yield estimated at the mouth of the Clear Creek watershed is less than that predicted from a relation between mean annual precipitation and water yield for eight watersheds instrumented in Eagle Valley. They suggest that the deficit could be caused in part by subsurface outflow from the upper part of the Clear Creek watershed moving southward towards Carson Valley. The deficit in water yield, about 3 in. over the 9,880 acres of the watershed (Maurer and Berger, 1997, fig. 11a, and table 9), amounts to about 2,500 acre-ft/yr. 
A.

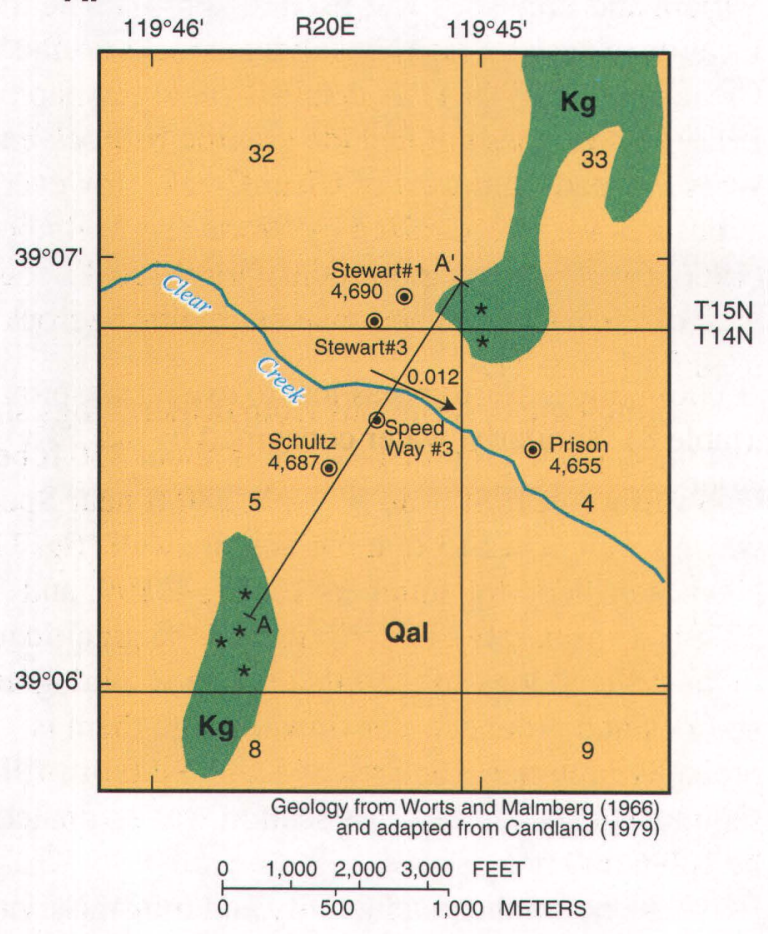

\section{EXPLANATION}

Geologic map and hydrogeologic section

\begin{tabular}{c|c} 
Qal Basin-fill sediments \\
Kg Granitic rocks
\end{tabular}

Geologic map

\begin{tabular}{|c|c|}
\hline $\mathrm{A} \longmapsto$ & Line of hydrogeologic section \\
\hline $\mathbf{P}^{0.012}$ & $\begin{array}{l}\text { Direction of subsurface flow- } \\
\text { Determined from water levels in } \\
\text { Stewart, Schultz, and Prison wells, } \\
\text { December } 19,1997 \text {. Number is } \\
\text { water-table gradient, in feet per foot }\end{array}$ \\
\hline $\begin{array}{l}\text { Stewart\#1 } \\
4,690 \\
\odot\end{array}$ & $\begin{array}{l}\text { Well and site name-Number is water } \\
\text { level altitude, December 19, } 1997\end{array}$ \\
\hline * & $\begin{array}{l}\text { Outcrop of granitic rock, mapped by } \\
\text { D.K. Maurer, } 1998\end{array}$ \\
\hline
\end{tabular}

Hydrogeologic section

- ? - Water table-Queried where uncertain

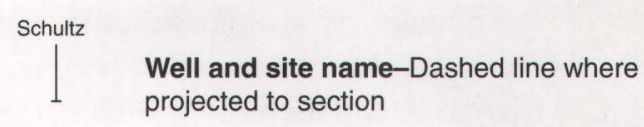

B.

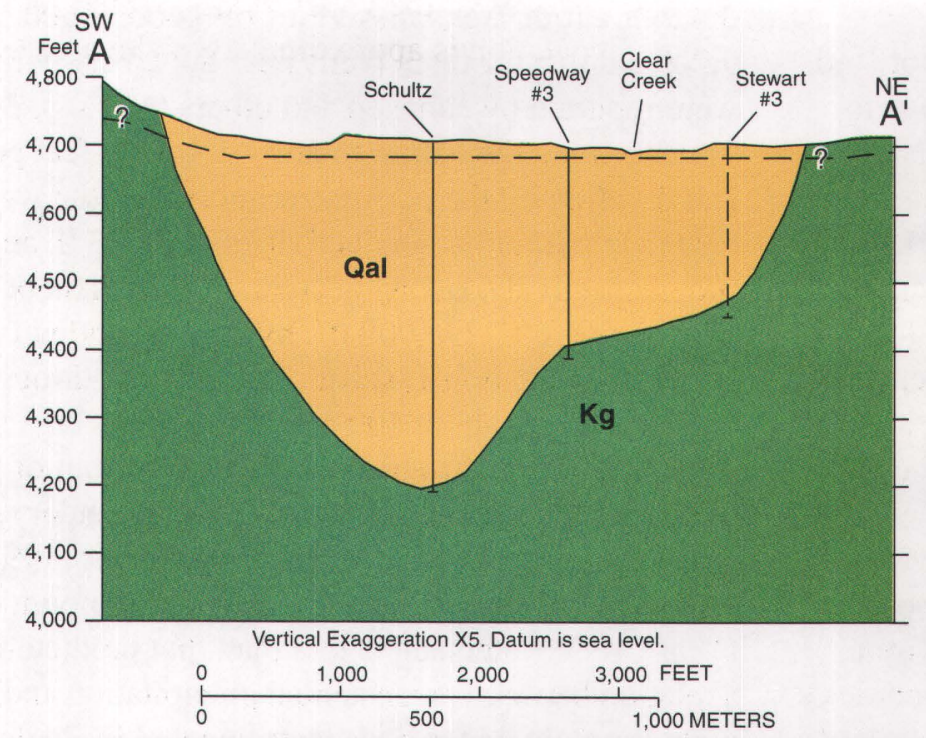

Figure 11. (A) Surficial geology, location of hydrogeologic section and wells used to determine hydraulic gradient, and hydraulic gradient, and $(B)$ hydrogeologic section showing water table in basin-fill sediments and bedrock, near southeast boundary of Eagle Valley Hydrographic Area. 
This ground-water flow has not been confirmed; however, the volume of 2,500 acre-ft/yr was used to account for all potential subsurface flow out of Eagle Valley, which totals 5,100 acre-ft/yr (table 7).

Outflow from beneath the floor of Eagle Valley was estimated at about 19,000 acre-ft/yr during 199598 , and about 15,000 acre-ft/yr for average conditions (table 7). The difference between inflow and outflow was about 21,000 acre-ft/yr for 1995-98 and 16,000 acre-ft/yr for average conditions (table 7). These differences represent discharge by evapotranspiration for average conditions and evapotranspiration and increases in ground-water storage for 1995-98, which have not been accounted for. As discussed previously, during 1995-98 water levels rose about 5-10 ft (fig. 3) showing an increase in ground-water storage in response to wet conditions. Under average conditions, the ground-water system appears to have adjusted to the stresses of municipal pumping, and annual longterm changes in ground-water storage are generally small.

Independent estimates of evapotranspiration can be used to show if estimates for the other components of the average overall water budget are reasonable. Water is lost to evapotranspiration from lawns, xerophytic plants such as sagebrush and bitterbrush, irrigated pastures, and phreatophytic vegetation such as greasewood and rabbitbrush (table 8). Evapotranspira- tion rates for these types of vegetation are not precisely known but can be estimated from available data and rates reported in the literature.

Seasonal variation of water use in Eagle Valley during 1994-97 (Tom Hoffert, Carson City Utilities Department, written commun., 1998) indicated that lawn irrigation from May through September averaged about 5,300 acre-ft/yr. From 800 to 2,300 acre-ft/yr has been estimated to recharge the water table beneath lawns for average conditions (table 6). The remaining $3,000-4,500$ acre-ft/yr was lost to evapotranspiration (table 8). Similarly, water consumed by lawns on golf courses can be estimated as the difference between the volume of treated effluent applied to golf courses, 1,100 acre-ft/yr (Kyle Menath, Carson City Utilities Department, written commun., 1998), and the estimate of recharge, 600 acre-ft/yr (table 6), resulting in consumption of 500 acre-ft/yr (table 8).

Annual consumptive use by xerophytic vegetation in Paradise Valley, Nev., was estimated to be 0.75 ft/yr (Loeltz and others, 1949, p. 35). Estimates of water yield from watersheds tributary to Eagle Valley (Maurer and Berger, 1997, p. 33) allow similar estimates of consumptive use, ranging from 0.67 to 1.04 $\mathrm{ft} / \mathrm{yr}$ for low-altitude watersheds with xerophytic vegetation like that on open areas on the floor of Eagle Valley. The area of the valley floor covered by xerophytic vegetation is approximated by the area of open

Table 8. Estimates of evapotranspiration from different types of land use on the floor of Eagle Valley

\begin{tabular}{|c|c|c|c|}
\hline Land-use type & $\begin{array}{l}\text { Area }^{a} \\
\text { (acres) }\end{array}$ & $\begin{array}{c}\text { Evapotranspiration rate } \\
\text { (feet per year) }\end{array}$ & $\begin{array}{l}\text { Consumptive use } \\
\text { (acre-feet per year) }\end{array}$ \\
\hline Lawns & 2,400 & $1.3-1.9^{b}$ & $3,000-4,500^{c}$ \\
\hline Golf courses & 320 & $1.6^{\mathrm{b}}$ & $500^{\mathrm{d}}$ \\
\hline Open land, xerophytic vegetation & $5,500^{e}$ & $0.67-1.04^{f}$ & $3,700-5,700$ \\
\hline Pastures & 650 & $1.0-1.5^{\mathrm{g}}$ & $650-980$ \\
\hline Open land-phyreatophytic vegetation & $1,100^{h}$ & $0.3-0.8^{i}$ & $330-880$ \\
\hline Total discharge, rounded & & & $8,000-13,000$ \\
\hline 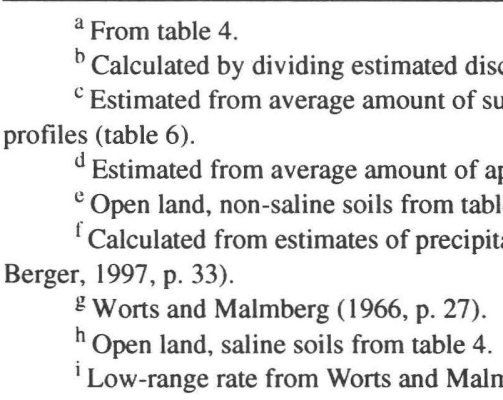 & $\begin{array}{l}\text { area. } \\
\text { ater use May } \\
\text { waent, } 1994\end{array}$ & $\begin{array}{l}\text { hber 1994-97, minus recharge } \\
\text { us recharge estimated from soi } \\
\text {-altitude watersheds tributary t }\end{array}$ & $\begin{array}{l}\text { imated from soil-chloride } \\
\text { hloride profiles. } \\
\text { Eagle Valley (Maurer and }\end{array}$ \\
\hline
\end{tabular}


land with non-saline soils (about 5,500 acres, table 4). Applying the range of 0.67 to $1.04 \mathrm{ft} / \mathrm{yr}$ to this area results in consumption of about 3,700 to 5,700 acre$\mathrm{ft} / \mathrm{yr}$ (table 8). Water consumed by vegetation on 650 acres of irrigated pastures (table 4) can be estimated by applying a range in rates of $1.0-1.5 \mathrm{ft} / \mathrm{yr}$ (Worts and Malmberg, 1966, p. 27) for meadow grasses and subirrigated pastures, resulting in 650-980 acre-ft/yr (table 8).

Remaining areas covered by phreatophytes in Eagle Valley have not been mapped, but can be approximated by the area of open land having saline soils indicative of ground-water discharge-about 1,100 acres (table 4). Worts and Malmberg (1966, p. 27) used a rate of $0.3 \mathrm{ft} / \mathrm{yr}$ for discharge by rabbitbrush and greasewood. Nichols (1994, p. 3271) estimated that transpiration by phreatophytes was $0.8 \mathrm{ft} / \mathrm{yr}$ where depth to water was $5 \mathrm{ft}$ below land surface. Using these rates, evapotranspiration by phreatophytes could range from 330 to 880 acre-ft/yr (table 8).

Discharge by evapotranspiration from all sources ranges from 8,000 to 13,000 acre-ft/yr (table 8). The higher quantity is close to the difference between inflow and outflow for average conditions $(16,000$ acre-ft/yr, table 7). The discrepancy of 3,000 acre-ft/yr is about 20 percent of the total discharge and could be caused by inaccuracies of estimates for water-budget components or estimates of evapotranspiration.

The accuracy of the overall water budget for 1995-98 can be checked using an independent estimate of the changes in ground-water storage for that period. The increase in ground-water storage from 1995-98 can be approximated by subtracting the estimated evapotranspiration for average conditions $(16,000$ acre-ft/yr) from the difference between inflow and outflow $(21,000 \mathrm{acre}-\mathrm{ft} / \mathrm{yr})$ resulting in 5,000 acre-ft/yr. The change in ground-water storage also can be approximated from observed rises in the water table from 1995-98, multiplied by the area of the valley floor, and the result multiplied by the average specific yield of the basin-fill aquifer materials. In general, the water levels rose 5-10 ft beneath the 13,600 acres of the valley floor (fig. 3, table 4), and sediments beneath the valley floor have an average specific yield of 0.15 (Worts and Malmberg, 1966, p. 11). The calculated change in ground-water storage ranged from 10,200 to 20,400 acre-ft over the 4-year period, or 2,600 to 5,100 acre-ft/yr. The higher quantity is similar to that estimated from the difference between inflow and outflow during 1995-98 minus estimated evapotranspiration, showing that estimates of water-budget components are reasonable.

For average conditions and for 1995-98, waterbudget components of greatest uncertainty are subsurface inflow from the mountains and out of the hydrographic area, inflow from ephemeral streams, and outflow of Clear Creek. These components are probably within about 20 percent of their actual value, whereas other components are gaged or metered flows within about 10 percent of their actual values.

To summarize, inflow to the floor of Eagle Valley totaled about 40,000 acre-ft/yr during 1995-98 and about 31,000 acre-ft/yr for average conditions. Average inflow includes 12,000 acre-ft/yr of precipitation and about 4,900 acre-ft/yr of water imported from outside the hydrographic area. Streamflow and subsurface inflow from the mountains total about 14,000 acre-ft/yr (table 7) for average conditions and are long-term sources not affected by changes in land use on the valley floor. However, streamflow is highly variable from year to year, ranging from an average of 9,900 acre$\mathrm{ft} / \mathrm{yr}$ to $14,000 \mathrm{acre}-\mathrm{ft} / \mathrm{yr}$ in wet years or $4,400 \mathrm{acre}-\mathrm{ft} / \mathrm{yr}$ in dry years. Subsurface inflow from the mountains varies much less, only about 20 percent from dry years to wet years, averaging 3,800 acre-ft/yr. Outflow during 1995-98 was about 19,000 acre-ft/yr and average outflow totals 15,000 acre-ft/yr, including 9,600 acre$\mathrm{ft} / \mathrm{yr}$ of streamflow and exported effluent and 5,100 acre-ft/yr of subsurface flow.

Some water-budget components, such as the volumes of water imported to or exported from the hydrographic area, may be greatly affected by watermanagement practices. Similarly, the volume of surface-water outflow from Eagle Valley may be affected by changes in the amount of streamflow used for municipal purposes, and the volume of subsurface outflow may be affected by changes in annual groundwater pumpage.

\section{Ground-Water Budget}

Included as recharge and inflow in the groundwater budget for the floor of Eagle Valley (table 9) are subsurface inflow from the mountains; infiltration of streamflow from Clear, Kings Canyon, and Ash Canyon Creeks, and ephemeral streams; and infiltration of precipitation, water from lawn and golf course irrigation, and effluent from septic tanks. Estimates of inflow are made for conditions during 1995-98 and for 
Table 9. Ground-water budget for floor of Eagle Valley, 1995-98 and average conditions

[All values in acre-feet per year (acre-ft/yr). Abbreviations: $\mathrm{ft}^{3} / \mathrm{s}$, cubic feet per second; gal/d, gallons per day]

\begin{tabular}{|c|c|c|c|c|}
\hline \multicolumn{3}{|c|}{ Recharge (inflow) to ground water } & \multicolumn{2}{|c|}{ Discharge (outflow) from ground water } \\
\hline & 1995-98 & Average & & $1995-98$ \\
\hline \multicolumn{5}{|c|}{ Subsurface flow } \\
\hline Inflow from mountain block & $4,600^{a}$ & $3,800^{\mathrm{a}}$ & Outflow to Dayton and Carson Valleys & $5,100^{b}$ \\
\hline \multicolumn{5}{|c|}{ Surface water } \\
\hline Infiltration from Clear Creek & $500^{\mathrm{c}}$ & $700^{c}$ & & \\
\hline $\begin{array}{l}\text { Infiltration from Kings and Ash Canyon } \\
\text { Creeks }\end{array}$ & $1,700^{\mathrm{c}}$ & $1,000^{\mathrm{c}}$ & Base streamflow of Eagle Valley creek & $200^{d}$ \\
\hline Infiltration from ephemeral streams & $1,300^{\mathrm{c}}$ & $900^{c}$ & Base streamflow of unnamed creeks & $170^{\mathrm{e}}$ \\
\hline Subtotal & 3,500 & 2,600 & Subtotal & 370 \\
\hline \multicolumn{5}{|c|}{ Precipitation, irrigation, and evapotranspiration } \\
\hline Infiltration of precipitation on open land & $30-90^{\mathrm{f}}$ & $30-90^{\mathrm{f}}$ & Ground-water evapotranspiration & $880^{\mathrm{g}}$ \\
\hline Irrigation of lawns & $960-2,400^{f}$ & $800-2,300^{f}$ & & \\
\hline Irrigation of golf courses & $600^{f}$ & $600^{f}$ & & \\
\hline Subtotal for lawn irrigation & $1,600-3,000$ & $1,400-2,900$ & & \\
\hline \multicolumn{5}{|c|}{ Septic tanks and pumpage } \\
\hline Septic tanks & $260^{h}$ & $260^{h}$ & Pumpage & $4,300^{i}$ \\
\hline Subtotal for recharge on valley floor & $5,400-6,900$ & $4,300-5,900$ & TOTAL, rounded & 11,000 \\
\hline TOTAL, rounded ${ }^{j}$ & $10,000-12,000$ & $8,000-10,000$ & & \\
\hline
\end{tabular}

${ }^{a}$ Twenty percent increase of average 3,800 acre-ft/yr from range of 3,200-4,400 acre-ft/yr estimated by Maurer and Berger (1997, p. 33) using low-range estimate of flow from Kings Canyon.

${ }^{\mathrm{b}}$ From table 7; includes 2,200 acre-ft/yr flow to Dayton Valley Hydrographic Area estimated by Maurer (1997, p. 31); 400 acre-ft/yr to Carson Valley Hydrographic Area, estimated in this report; and 2,500 acre-ft/yr flow to Carson Valley Hydrographic Area from upper part of Clear Creek watershed (Maurer and Berger, 1997, p. 34).

${ }^{\mathrm{c}}$ From table 2.

${ }^{\mathrm{d}}$ Estimate based on average flow of Eagle Valley creek during October-November $1987-98\left(0.27 \mathrm{ft}^{3} / \mathrm{s}\right)$ and assumption that base flow is present throughout the year.

'Estimated using relation in figure 10, and base flow of $0.27 \mathrm{ft}^{3} / \mathrm{s}$ in Eagle Valley creek.

${ }^{\mathrm{f}}$ From table 6.

g Maximum estimate of evapotranspiration, table 11.

${ }^{\mathrm{h}}$ Estimated from assumed rate of $250 \mathrm{gal} / \mathrm{d}$ per tank multiplied by an estimated 900 tanks functioning in 1997 , for 0.7 acre-ft per day $\times 365$ days (Leanna Stevens, Carson City Utilities Department, oral and written communs., 1998).

${ }^{\mathrm{i}}$ Includes municipal pumpage of 3,100 acre-ft/yr; quasi-municipal, commercial, industrial, irrigation and stock pumpage of $400 \mathrm{acre-ft/yr;} \mathrm{and}$ domestic pumpage of 800 acre-ft/yr (Dillon, 1995, p. 5; Leanna Stevens, Carson City Utilities Department, oral and written communs., 1998).

${ }^{\mathrm{j}}$ Subtotal for recharge on valley floor plus subsurface flow from mountain block. 
average conditions. Discharge and outflow consists of subsurface flow, pumpage, ground-water contribution to base flow of Eagle Valley creek and unnamed creeks, and ground-water evapotranspiration. Because most components of outflow probably did not change appreciably from wet conditions of 1995-98, they are considered to be representative of average conditions.

Subsurface inflow from the mountains is not strictly considered recharge as it does not cross the water table, but flows laterally into the basin-fill aquifer beneath the floor of Eagle Valley. As discussed in the previous section, this inflow was about 4,600 acre$\mathrm{ft} / \mathrm{yr}$ during 1995-98 and about 3,800 acre-ft/yr for average conditions (table 9). Recharge from infiltration of streamflow was about 3,500 acre-ft/yr during 199598 and about 2,600 acre- $\mathrm{ft} / \mathrm{yr}$ for average conditions (tables 2 and 9).

Recharge from precipitation on open areas of the valley floor ranges from 30 to 90 acre-ft/yr (table 9). Recharge from lawn irrigation is estimated to range from 800 to 2,300 acre-ft/yr for average conditions, increasing slightly to 960 to 2,400 acre-ft/yr for 1995 98. Recharge from irrigation of golf courses with treated effluent is about $600 \mathrm{acre}-\mathrm{ft} / \mathrm{yr}$. Thus, recharge from irrigation of lawns totalled about 1,600 to 3,000 acre-ft/yr during 1995-98 and 1,400 to 2,900 for average conditions. About 900 septic tanks were estimated to have been functioning in Eagle Valley in 1997 with an estimated use and infiltration of $250 \mathrm{gal} / \mathrm{d}$ per tank (Leanna Stevens, Carson City Public Utilities Department, oral and written communs., 1998). Recharge from 900 septic tanks is about 0.7 acre-ft/day, or about $260 \mathrm{acre}-\mathrm{ft} / \mathrm{yr}$. Thus, total recharge from sources on the valley floor ranged from 5,400 to $6,900 \mathrm{acre}-\mathrm{ft} / \mathrm{yr}$ for 1995-98 and from 4,300 to 5,900 acre-ft/yr for average conditions (table 9).

Subsurface outflow from the hydrographic area beneath the valley floor is about 5,100 acre-ft/yr (table 9). As discussed in the section titled "Water Use," ground-water pumpage within Eagle Valley was about 4,300 acre-ft/yr from 1995-98 (table 9).

Where the water table is close to land surface, ground water also discharges as seepage to Eagle Valley creek and two unnamed creeks (fig. 1) and as evapotranspiration from phreatophytes. Ground-water seepage to Eagle Valley creek was estimated by determining average base flow gaged during the months of October and November from 1987 to 1998 . Prior to September 1987, flow gaged at Eagle Valley creek included treated effluent (Kyle Menath, Carson City
Utilities Department, oral commun., 1998). During October and November, prior to large winter storms, runoff remaining from Kings Canyon and Ash Canyon Creeks and evapotranspiration were assumed to be minimal, and base flow was assumed to be present throughout the year. During 1997-98, above-normai precipitation during fall months did not allow estimation of base flow. Base flow ranged from 0.07 to 1.0 $\mathrm{ft}^{3} / \mathrm{s}$, and averaged $0.27 \mathrm{ft}^{3} / \mathrm{s}$, or about 200 acre-ft/yr (table 9). Using the relation between Eagle Valley creek and the unnamed creeks (fig. 10), base flow at the unnamed creeks is about 170 acre- $\mathrm{ft} / \mathrm{yr}\left(0.24 \mathrm{ft}^{3} / \mathrm{s}\right)$. Evapotranspiration of ground water by phreatophytes was estimated to range from 330 to $880 \mathrm{acre}-\mathrm{ft} / \mathrm{yr}$ (table 8 ) and during 1995-98 was probably a maximum value.

The total for all sources of ground-water recharge and inflow ranged from 10,000 to 12,000 acre- $\mathrm{ft} / \mathrm{yr}$ for $1995-98$, and from 8,000 to 10,000 acre-ft/yr for average conditions (table 9). Ground-water recharge and inflow vary much less from wet to dry conditions than inflow in the overall water budget. Estimates of ground-water discharge and outflow for 1995-98 are probably similar to average conditions and total 11,000 acre-ft/yr. Estimates of inflow are as much as 1,000 acre-ft/yr greater than estimated outflow during 199598 , representative of the increase in ground-water storage. The quantity of $1,000 \mathrm{acre}-\mathrm{ft} / \mathrm{yr}$ is less than the lowest estimate of increased storage calculated in the previous section from observed rises in water levels on the valley floor $(2,600 \mathrm{acre}-\mathrm{ft} / \mathrm{yr})$. This suggests that inflow could be underestimated, or that outflow could be overestimated. An overestimate of outflow is possible, as 2,500 acre-ft/yr of subsurface flow out of the hydrographic area beneath the southern boundary of the Clear Creek watershed has not been confirmed. Also, the difference suggests that estimates of groundwater-budget components are probably within 20 percent of their actual values. Water-budget components of greatest uncertainty are subsurface outflow, recharge from ephemeral streamflow, and recharge from lawn irrigation.

To summarize, average recharge and inflow to the basin-fill aquifer beneath the floor of Eagle Valley totals 8,000 to 10,000 acre-ft/yr, including 3,800 acre$\mathrm{ft} / \mathrm{yr}$ of subsurface inflow from the mountains, 2,600 acre-ft/yr from infiltration of streamflow, 1,400 to 2,900 acre-ft/yr from irrigation of lawns, 30-90 acre$\mathrm{ft} / \mathrm{yr}$ from infiltration of precipitation on open land with non-saline soils, and 260 acre-ft/yr from septic tanks. 
Ground-water discharge and outflow totals 11,000 acre-ft/yr, including 5,100 acre-ft/yr of subsurface outflow, 4,300 acre-ft/yr of pumpage, 370 acre-ft/yr of base streamflow, and 880 acre-ft/yr of evapotranspiration.

With increased development causing a greater percentage of land to become impervious or irrigated for lawns and golf courses, natural ground-water discharge by evapotranspiration will continue to decrease. This, coupled with increased recharge from lawn and golf course irrigation, could result in the water table rising to near land surface in the lower parts of Eagle Valley.

\section{CHEMICAL QUALITY OF RECHARGE AND INFLOW}

To allow evaluation of the potential for groundwater contamination, the chemical quality of precipitation, surface and ground water, municipal supply water, and treated effluent is described in terms of Nevada drinking water standards (table 10). Chemical analyses used in this section were from USGS and Laird and others (1986, p. 22-25) for precipitation, from data collected by USGS during this study for surface and ground water, and from data supplied by Carson City Utilities Department for municipal supply water and treated effluent.

Precipitation is the source of all water in Eagle Valley. Most precipitation accumulates as a winter snowpack in the surrounding mountains and lesser amounts fall as snow and rain on the valley floor. Analyses of 16 snow samples collected near the crest of the Sierra Nevada between latitudes $39^{\circ}$ and $40^{\circ} \mathrm{N}$ in early 1983 (Laird and others, 1986, p. 22-25) are summarized in table 11. The samples represent wet- and dry-fall deposition at high altitudes but may not be representative of precipitation that falls on the floor of Eagle Valley, east of the Sierra Nevada. The mean concentration of chloride is $0.32 \mathrm{mg} / \mathrm{L}$, which is less than the average value of $0.4 \mathrm{mg} / \mathrm{L}$ for wet- and dry-fall deposition from samples collected elsewhere in Nevada by Dettinger (1989, p. 63) and Berger and others (1997, p. 46). Nonetheless, the data are presented in table 11 as the only data set available for a relatively large suite of constituents. Analysis of precipitation collected about 35 mi southeast of Carson City in Smith Valley during 1986-97 (National Atmospheric Deposition Program (NRSP-3)/National Trends Network, 1999), which represent wet-fall deposition only, also are summarized in table 11. The site in Smith Valley is

Table 10. Nevada drinking water standards ${ }^{a}$

\begin{tabular}{lccc}
\hline \multicolumn{1}{c}{ Property or Constituent } & Primary maximum & Secondary maximum & Secondary preferred \\
\hline Total dissolved solids (mg/L) & -- & 500 & 1,000 \\
pH (standard units) & -- & -- & $6.5-8.5$ \\
Magnesium $(\mathrm{mg} / \mathrm{L})$ & -- & 150 & 125 \\
Sulfate $(\mathrm{mg} / \mathrm{L})$ & -- & 500 & 250 \\
& & & 250 \\
Chloride $(\mathrm{mg} / \mathrm{L})$ & -- & 400 & -- \\
Fluoride $(\mathrm{mg} / \mathrm{L})$ & 4.0 & 2.0 & -- \\
Nitrate $(\mathrm{mg} / \mathrm{L}$ as N) & 10 & -- & -- \\
Arsenic $(\mathrm{mg} / \mathrm{L})$ & .05 & -- & -- \\
Cadmium $(\mu \mathrm{g} / \mathrm{L})$ & .01 & -- & 1.0 \\
& & & .3 \\
Copper $(\mu \mathrm{g} / \mathrm{L})$ & -- & -- & -- \\
Iron $(\mu \mathrm{g} / \mathrm{L})$ & -- & .6 & .05 \\
Lead $(\mu \mathrm{g} / \mathrm{L})$ & .05 & -- & 5.0 \\
Manganese $(\mu \mathrm{g} / \mathrm{L})$ & -- & .1 & - \\
Zinc $(\mathrm{mg} / \mathrm{L})$ & -- & -- & \\
\hline
\end{tabular}

${ }^{a}$ Standards referred to are those of Nevada Administrative Code (1992). Primary maximum standards are health related and enforceable by State, and secondary maximum standards are based on aesthetic qualities and also are enforceable; both require use of best available technology to achieve standards. Secondary preferred standards are not enforceable but must be met unless water of that quality is not available. 
Table 11. Summary of water-quality data reported for snow cores from Sierra Nevada and precipitation samples from Smith Valley, Nevada

[Abbreviations: $\mu \mathrm{g} / \mathrm{L}$, micrograms per liter; $\mu \mathrm{S} / \mathrm{cm}$, microsiemens per centimeter at 25 degrees Celsius; $\mathrm{mg} / \mathrm{L}$, milligrams per liter; --, constituent not analyzed for, or mean not calculated for log or "less than" values]

\begin{tabular}{|c|c|c|c|c|c|c|c|c|}
\hline $\begin{array}{l}\text { Property or } \\
\text { constituent }\end{array}$ & \multicolumn{4}{|c|}{$\begin{array}{l}\text { Sierra Nevada snow chemistry } \\
\text { (Laird and others, 1986, p. 22-25) a }\end{array}$} & \multicolumn{4}{|c|}{$\begin{array}{c}\text { Volume-weighted annual mean values, Smith Valley, Nevada } \\
\text { 1986-97 (National Atmospheric Deposition Program (NRSP- } \\
\text { 3)/National Trends Network, January 4, 1999) }\end{array}$} \\
\hline $\mathrm{pH}$ & 5.47 & 5.68 & -- & 5.72 & 5.4 & 5.6 & -- & 5.9 \\
\hline Magnesium (mg/L) & $<.003$ & .003 & -- & .016 & .007 & .016 & 0.016 & .027 \\
\hline Sulfate $(\mathrm{mg} / \mathrm{L})$ & .04 & .14 & 0.13 & .21 & .25 & .32 & .40 & .71 \\
\hline Fluoride $(\mathrm{mg} / \mathrm{L})$ & $<.01$ & .02 & -- & .03 & -- & -- & -- & -- \\
\hline Nitrate (mg/L as $\mathrm{N}$ ) & .016 & .026 & .026 & .041 & .45 & .62 & .70 & 1.27 \\
\hline Cadmium $(\mu \mathrm{g} / \mathrm{L})$ & .037 & .068 & .08 & .16 & -- & -- & -- & - \\
\hline Copper $(\mu \mathrm{g} / \mathrm{L})$ & .17 & .23 & .27 & .59 & -- & -- & -- & -- \\
\hline
\end{tabular}

${ }^{a}$ Includes wet- and dry-fall deposition for 16 sites along Sierra Nevada between latitudes $39^{\circ}$ and $40^{\circ} \mathrm{N}$ in early 1983.

${ }^{\mathrm{b}}$ Includes wet-fall deposition only, for 110 monthly mean values. Site is about 35 miles southeast of Eagle Valley and 58 miles east of Sierra Nevada.

about 58 mi east of the Sierra Nevada crest and 110 monthly mean values were used. Both forms of precipitation are dilute and none of the analytes exceed Nevada drinking-water standards (Nevada Administrative Code, 1992).

For this study, samples for chemical analyses were collected from 4 surface-water sites (sites 9-11 on Kings Canyon and Ash Canyon Creeks, and site 1 on Clear Creek) and from 17 ground-water sites near the periphery of the valley (fig. 4). A total of 77 samples (24 ground water and 53 surface water) were collected between November 1994 and September 1997 and sent to the USGS National Water Quality Laboratory (NWQL) in Arvada, Colo., for analyses of major constituents, trace elements, and nutrients. Laboratory quality-assurance procedures are described by Pritt and Raese (1995). Field procedures for collection and processing of ground-water samples were similar to those recommended by Koterba and others (1995, p. 51-63) and procedures for surface-water samples were similar to those recommended by Shelton (1994). The results of these analyses have been published by the U.S. Geological Survey in annual water-resources data reports for Nevada (Bauer and others, 1996, p. 611; Bostic and others, 1997, p. 505-507; Bonner and others, 1998, p. 517-519).
A statistical water-quality summary for streamflow and ground-water samples collected for this study is presented in table 12. For sites where more than one sample was taken over time, concentrations from all samples were averaged for the statistical summary.

Surface water from Clear, Kings Canyon, North Kings Canyon, and Ash Canyon Creeks (53 samples from 4 sites at stream-gaging stations, fig. 4) was analyzed for dissolved chloride and seven of these samples were analyzed for major constituents, trace elements, and species of nitrogen and phosphorus. Surface water from these streams is also dilute. Measured dissolvedsolids concentrations ranged from $44 \mathrm{mg} / \mathrm{L}$ at the North Kings Canyon Creek on September 6, 1996 (Bostic and others, 1997, p. 506), to $122 \mathrm{mg} / \mathrm{L}$ at Clear Creek on June 12, 1997 (Bonner and others, 1998, p. 519). Kings Canyon Creek had the highest concentrations of arsenic $(4 \mu \mathrm{g} / \mathrm{L})$ and uranium $(13 \mu \mathrm{g} / \mathrm{L}$; Bostic and others, 1997, p. 506), but these concentrations and concentrations of other regulated analytes all are less than Nevada State drinking water standards. Concentrations of dissolved chloride in Clear and Kings Canyon Creeks ranged from a minimum of $2.5 \mathrm{mg} / \mathrm{L}$ on December 6, 1996, to $37 \mathrm{mg} / \mathrm{L}$ on February 16, 1996 (Bostic and others, 1997, p. 507; Bonner and others, 1998, p. 518). These concentrations are higher than 
Table 12. Summary of water-quality data collected from selected surface- and ground-water sites, Eagle Valley, Nevada, 1994-97

[Mean concentration used in statistical computations for sites having more than one sample. Concentrations are in milligrams per liter unless otherwise noted. Data are based on values from Bauer and others (1996, p. 611), Bostic and others (1997, p. 505-507), and Bonner and others (1998, p. 517-519). Abbreviations: ${ }^{\circ} \mathrm{C}$, degrees Celsius; <, less than; $\mu \mathrm{g} / \mathrm{L}$, microgram per liter; $\mu \mathrm{S} / \mathrm{cm}$, microsiemens per centimeter at $25^{\circ} \mathrm{C} ; \mathrm{N}$, nitrogen; NA, not applicable; $\mathrm{P}$, phosphorus.]

\begin{tabular}{|c|c|c|c|c|c|c|c|c|c|c|c|}
\hline \begin{tabular}{|c|}
$\begin{array}{c}\text { Property } \\
\text { or constituent }\end{array}$ \\
$\mathrm{pH}$ (standard units)
\end{tabular} & $\begin{array}{c}\text { Source } \\
\text { Surface water }\end{array}$ & $\begin{array}{c}\text { Number } \\
\text { of values }\end{array}$ & $\begin{array}{c}\text { Number of } \\
\text { values less than } \\
\text { analytical } \\
\text { reporting limit a } \\
0\end{array}$ & $\begin{array}{c}\text { Mean } \\
8.0\end{array}$ & \multicolumn{2}{|c|}{$\begin{array}{l}\text { Minimum } \\
\text { (site number, } \\
\text { fig. } 4 \text { in } \\
\text { parentheses) }\end{array}$} & $\begin{array}{c}\begin{array}{c}\text { 25th } \\
\text { percentile }\end{array} \\
\text { NA }\end{array}$ & $\begin{array}{c}\begin{array}{c}50 \text { th } \\
\text { percentile } \\
\text { (median) }\end{array} \\
\text { NA }\end{array}$ & $\begin{array}{c}\text { 75th } \\
\text { percentile } \\
\text { NA }\end{array}$ & \multicolumn{2}{|c|}{$\begin{array}{c}\text { Maximum } \\
\text { (site number, } \\
\text { fig. } 4 \\
\text { in parentheses) }\end{array}$} \\
\hline & Ground water & 17 & 0 & 7.4 & 6.8 & (11) & 6.9 & 7.4 & 7.6 & 8.9 & (14) \\
\hline \multirow[t]{2}{*}{ Magnesium } & Surface water & 4 & 0 & 2.9 & 1.4 & (9) & NA & NA & NA & 5.0 & (1) \\
\hline & Ground water & 17 & 0 & 6.7 & .71 & (14) & 3.1 & 6.5 & 7.4 & 20 & (4) \\
\hline \multirow[t]{2}{*}{ Sulfate } & Surface water & 4 & 0 & .72 & .20 & (9) & NA & NA & NA & 1.0 & (1) \\
\hline & Ground water & 17 & 0 & 16 & 1.8 & (17) & 5.0 & 10 & 29 & 42 & (8) \\
\hline \multirow[t]{2}{*}{ Chloride } & Surface water & 51 & 0 & 5.2 & .2 & (12) & .3 & .6 & 2.5 & 37 & (1) \\
\hline & Ground water & 17 & 0 & 10 & 1.3 & (6) & 2.0 & 3.1 & 7.2 & 95 & (4) \\
\hline \multirow[t]{2}{*}{ Fluoride } & Surface water & 4 & 4 & NA & $<.1$ & NA & NA & NA & NA & $<.1$ & NA \\
\hline & Ground water & 17 & 4 & NA & $<.1$ & NA & $<.1$ & .12 & .19 & .32 & (2) \\
\hline Nitrate (as N) & Ground water & 7 & 0 & 3.5 & 1.14 & (13) & 1.6 & 2.3 & 2.6 & 11 & (4) \\
\hline \multirow[t]{2}{*}{ Arsenic $(\mu \mathrm{g} / \mathrm{L})$} & Surface water & 4 & 3 & NA & $<1$ & NA & NA & NA & NA & 4 & (11) \\
\hline & Ground water & 15 & 1 & NA & $<1$ & NA & 2 & 3 & 4 & 19 & (13) \\
\hline \multirow[t]{2}{*}{ Cadmium $(\mu \mathrm{g} / \mathrm{L})$} & Surface water & 4 & 4 & NA & $<1$ & NA & NA & NA & NA & $<1$ & NA \\
\hline & Ground water & 15 & 15 & NA & $<1$ & NA & $<1$ & $<1$ & $<1$ & $<1$ & NA \\
\hline \multirow[t]{2}{*}{ Copper $(\mu \mathrm{g} / \mathrm{L})$} & Surface water & 4 & 4 & NA & $<1$ & NA & NA & NA & NA & $<1$ & NA \\
\hline & Ground water & 15 & 12 & NA & $<1$ & NA & $<1$ & $<1$ & $<1$ & 1 & (11) \\
\hline \multirow[t]{2}{*}{ Iron $(\mu \mathrm{g} / \mathrm{L})$} & Surface water & 4 & 0 & 134 & 6 & (12) & NA & NA & NA & 250 & (1) \\
\hline & Ground water & 15 & 9 & NA & $<3$ & NA & $<3$ & $<3$ & 10 & 490 & (16) \\
\hline \multirow[t]{2}{*}{ Lead $(\mu \mathrm{g} / \mathrm{L})$} & Surface water & 4 & 4 & NA & $<1$ & NA & NA & NA & NA & $<1$ & NA \\
\hline & Ground water & 15 & 15 & NA & $<1$ & NA & $<1$ & $<1$ & $<1$ & $<1$ & NA \\
\hline \multirow[t]{2}{*}{ Manganese $(\mu \mathrm{g} / \mathrm{L})$} & Surface water & 4 & 0 & 10 & 1 & (12) & NA & NA & NA & 17 & (1) \\
\hline & Ground water & 15 & 2 & NA & $<1$ & NA & 2 & 8 & 39 & 110 & (16) \\
\hline
\end{tabular}

${ }^{a}$ For sites where more than one sample was taken over time, concentrations from all samples were averaged for summary. 
those measured in North Kings Canyon and Ash Canyon Creeks, and suggest that runoff of road salt applied to adjacent highways and roads during winter months affects the water quality of Clear Creek and Kings Canyon Creeks.

Ground water entering Eagle Valley as subsurface inflow from the surrounding mountains ( 24 samples from 17 sites, fig. 4) was analyzed for major constituents, and selected samples also were analyzed for trace elements and selected species of nitrogen and phosphorus. Concentrations of dissolved solids ranged from $102 \mathrm{mg} / \mathrm{L}$ at site 16 to $423 \mathrm{mg} / \mathrm{L}$ at site 4 (fig. 4 , table 11; Bonner and others, 1997, p. 518). The Nevada State drinking water standard for nitrate $(10 \mathrm{mg} / \mathrm{L}$ as nitrogen) was exceeded in one sample from site 4, a shallow well on the Eagle Valley golf course (fig. 4). Nitrate concentrations at sites 3,14 , and 1 were $2.3,2.5$, and $3.7 \mathrm{mg} / \mathrm{L}$, respectively (fig. 4; Bonner and others, 1997 , p. 518). At site 16, the concentration of iron, $0.49 \mathrm{mg} / \mathrm{L}$ (Bostic and others, 1998, p. 506), approached the secondary preferred standard of $0.6 \mathrm{mg} / \mathrm{L}$, and the concentration of manganese, $0.11 \mathrm{mg} / \mathrm{L}$, exceeded the secondary maximum standard of $0.1 \mathrm{mg} / \mathrm{L}$. Although not analyzed for this study, Welch and others (1997, p. A68) note that activities of radon-222 along the western side of Eagle Valley commonly exceed the maximum standard of 300 picocuries per liter $(\mathrm{pCi} / \mathrm{L})$, with some values higher than $2,700 \mathrm{pCi} / \mathrm{L}$.

Analyses of municipal water and treated effluent supplied for irrigation were obtained from records of Carson City Utilities Department (Tom Hoffert, written commun., 1998; Kelvin Ikehara, written and oral communs., 1998). Analyses for major constituents, trace elements, and selected species of nitrogen showed that from 1994 to 1997, municipal supply water was within most Nevada drinking-water standards (table 13). Concentrations of total dissolved solids, sulfate, and iron exceeded secondary preferred standards in 1997 on the east side of U.S. Highway 395.

Effluent treated by Carson City Utilities Department and effluent from septic tanks are the most likely sources of ground-water contamination among all categories of recharge. Samples of effluent from the treatment plant taken in 1993-98 had dissolved-solids concentrations of 480 to $496 \mathrm{mg} / \mathrm{L}$, respectively, which are close to the secondary preferred standard. In 1997, plant effluent had concentrations of arsenic, cadmium, and lead of $0.25,0.01$, and $0.05 \mathrm{mg} / \mathrm{L}$, respectively,

Table 13. Summary of water-quality data for municipal supply water, 1994-97, and treated effluent from wastewater reclamation plant, 1993-98, and from Brunswick reservoir, 1987-91

[All data are from Carson City Utilities Department. Abbreviations: $\mu \mathrm{S} / \mathrm{cm}$, microsiemens per centimeter at 25 degrees Celsius; $\mu \mathrm{g} / \mathrm{L}$, micrograms per liter; $\mathrm{mg} / \mathrm{L}$, milligrams per liter; --, no data]

\begin{tabular}{|c|c|c|c|c|c|c|}
\hline \multirow{2}{*}{ Property or constituent } & \multicolumn{2}{|c|}{$\begin{array}{l}\text { Municipal } \\
\text { supply water }\end{array}$} & \multicolumn{2}{|c|}{$\begin{array}{c}\text { Wastewater reclamation } \\
\text { plant treated effluent }\end{array}$} & \multicolumn{2}{|c|}{ Brunswick reservoir } \\
\hline & Minimum & Maximum & Minimum & Maximum & Minimum & Maximum \\
\hline Total dissolved solids (mg/L) & 56 & 586 & 480 & 496 & -- & -- \\
\hline pH (standard units) & 7.05 & 8.00 & 7.34 & 7.61 & -- & -- \\
\hline Magnesium (mg/L) & .81 & 5.32 & 1.41 & 7.70 & 5.1 & 8.2 \\
\hline Sulfate $(\mathrm{mg} / \mathrm{L})$ & 1.9 & 272 & 105 & 157 & -- & -- \\
\hline Chloride (mg/L) & 1 & 16.7 & 46.2 & 83.2 & -- & -- \\
\hline Fluoride (mg/L) & .05 & 1.26 & .98 & 1.56 & -- & -- \\
\hline Nitrate $(\mathrm{mg} / \mathrm{L}$ as $\mathrm{N})$ & .5 & .73 & .10 & 2.46 & 7.84 & 10.8 \\
\hline Arsenic (mg/L) & $<.002$ & .008 & .008 & .25 & -- & -- \\
\hline Cadmium $(\mu \mathrm{g} / \mathrm{L})$ & $<.001$ & $<.05$ & $<.01$ & .01 & -- & -- \\
\hline Copper $(\mu \mathrm{g} / \mathrm{L})$ & $<.5$ & .26 & $<.05$ & .02 & -- & -- \\
\hline Iron $(\mu \mathrm{g} / \mathrm{L})$ & .02 & .32 & .1 & .19 & .02 & .85 \\
\hline Lead $(\mu \mathrm{g} / \mathrm{L})$ & $<.010$ & $<.10$ & .05 & .05 & -- & -- \\
\hline Manganese $(\mu \mathrm{g} / \mathrm{L})$ & $<.02$ & $<.05$ & .02 & .06 & .008 & .66 \\
\hline Zinc (mg/L) & $<.02$ & $<.05$ & .02 & .08 & -- & -- \\
\hline
\end{tabular}


which were at or above the maximum drinking water standard. Effluent from the plant is applied to the Eagle Valley golf course and may be applied to the Silver Oaks golf course, although Silver Oaks is probably supplied largely by effluent from Brunswick reservoir during summer months (Kelvin Ikehara, Carson City Utilities Department, oral commun., 1999). Samples obtained from Brunswick reservoir from 1987 to 1991 had concentrations of nitrate as high as $10.8 \mathrm{mg} / \mathrm{L}$, exceeding the maximum drinking-water standards, and concentrations of iron and manganese as high as 0.85 and $0.66 \mathrm{mg} / \mathrm{L}$, respectively, exceeding the secondary maximum drinking-water standards. Water quality of effluent stored in the reservoir could be affected by contact with soils underlying the reservoir.

Water-quality samples from septic tanks were not taken for this study; however, septic tanks may be the source of nitrate contamination of ground water (Nightingale and McCormick, 1985, p. 916; Lawrence, 1996, p. 18). The potential for contamination from septic tanks depends on factors such as local soil properties, water table depth, subsurface geology, and vegetation. The extent of, or potential for, contamination from existing septic tanks in Eagle Valley is not known.

\section{SUMMARY AND CONCLUSIONS}

Continued growth of Carson City, the capital of Nevada, is increasing the demand for municipal water supply, much of which is pumped from ground water in the basin-fill aquifer beneath the floor of Eagle Valley. The basin-fill aquifer can be recharged by subsurface inflow from the adjacent mountains and by infiltration of streamflow, precipitation, and water applied for irrigation on the valley floor.

In 1994, the U.S. Geological Survey began a study designed to estimate water resources of Eagle Valley as part of a cooperative program with Carson City Utilities Department and the Washoe Tribe of Nevada and California. Initial study focused on estimating the quantity of water entering the floor of Eagle Valley from the surrounding mountains. In 1996, the U.S. Geological Survey began studies to estimate ground-water recharge on the valley floor from infiltration of streamflow, precipitation, and water applied for irrigation. These estimates, combined with estimates of water yield from the surrounding mountains and estimates of other water-budget elements, allowed for development of an updated overall water budget and ground-water budget for the valley floor for use by water managers. Estimates were made for 1995-98, when precipitation was 140 percent of normal, and for average conditions.

Periodic streamflow measurements were made during 1996-98 at eight sites along Clear Creek from the gaging station, upstream from the bedrock/basinfill contact, to the Eagle Valley Hydrographic-Area boundary. The measurements show that the reach is in close connection with a fluctuating water table. A linear relation developed from the measurements was used to estimate the average flow of Clear Creek where it exits the valley, resulting in outflow of 6,100 acre$\mathrm{ft} / \mathrm{yr}$ for 1995-98 and 3,500 acre-ft/yr for average conditions. Estimates of recharge from infiltration were 500 acre-ft/yr during 1995-98 and 700 acre-ft/yr for average conditions.

Periodic streamflow measurements were made during 1996-98 at seven sites along Kings Canyon and Ash Canyon Creeks from the bedrock contact to the point where streamflow enters subsurface culverts. The measurements show that, after municipal diversions, the streams lose flow to infiltration over the entire reach. A linear relation from the measurements was used to estimate the average flow during April through September that is lost to infiltration. Infiltration during November through March was calculated from measurements of diurnal temperature fluctuations of streamflow and at increasing depths beneath the streambed. Subtracting estimates of flow lost to infiltration upstream from the valley floor ( 70 to 100 acre$\mathrm{ft} / \mathrm{yr}$ ) and infiltrated water lost to evapotranspiration (200 to 300 acre-ft/yr), recharge from infiltration was about 1,700 acre-ft/yr during 1995-98 and is about 1,000 acre- $\mathrm{ft} / \mathrm{yr}$ during average conditions.

Rates of recharge from infiltration of precipitation and water applied for irrigation were determined from the concentration of chloride in soil profiles above the water table at 16 sites. Recharge estimates at the sites were applied to areas of similar land use for the floor of Eagle Valley, as determined from aerial photographs taken in 1997. The distribution of chloride in the unsaturated zone suggests that recharge from precipitation is minimal in open areas and infrequently irrigated pastures with saline soils, and that recharge from lawn watering and flood irrigation of pastures has flushed salts from saline soils. Estimates of recharge from precipitation on 5,500 acres of open areas with non-saline soils range from 30 to 90 acre-ft/yr. Estimates of 
recharge from precipitation and water applied for irrigation of lawns ranged from 960 to $2,400 \mathrm{acre}-\mathrm{ft} / \mathrm{yr}$ for 1995-98 and from 800 to 2,300 acre-ft/yr for average conditions. Estimated recharge from precipitation and irrigation of golf courses with treated effluent was about 600 acre-ft/yr.

In the overall water budget, total estimated inflow to the valley floor for $1995-98$ was 40,000 acre- $\mathrm{ft} / \mathrm{yr}$, and for average conditions was 31,000 acre-ft/yr. Average inflow includes 12,000 acre-ft/yr of precipitation and about 4,900 acre-ft/yr imported from outside the hydrographic area. Inflow of streamflow and subsurface inflow from the mountains average 14,000 acre$\mathrm{ft} / \mathrm{yr}$ and are long-term sources not affected by changes in land use on the valley floor. However, streamflow is highly variable from year to year, ranging from an average of 9,900 acre- $\mathrm{ft} / \mathrm{yr}$ to $14,000 \mathrm{acre}-\mathrm{ft} / \mathrm{yr}$ in wet years or 4,400 acre-ft/yr in dry years. Subsurface inflow from the mountains varies much less, only about 20 percent from dry years to wet years, averaging 3,800 acre-ft/yr. Estimates of outflow total 19,000 acre-ft/yr during 1995-98 and 15,000 acre-ft/yr for average conditions. Average outflow includes 9,600 acre-ft/yr of streamflow and export of treated effluent and subsurface outflow of 5,100 acre-ft/yr.

In the ground-water budget, the total for all sources of recharge and inflow ranges from 10,000 to 12,000 acre-ft/yr for $1995-98$ and from 8,000 to $10,000 \mathrm{acre}-\mathrm{ft} / \mathrm{yr}$ for average conditions, varying much less from wet to dry conditions than inflow in the overall water budget. Average recharge and inflow includes 3,800 acre-ft/yr of subsurface inflow from the mountains, 2,600 acre-ft/yr from infiltration of streamflow, 1,400 to $2,900 \mathrm{acre}-\mathrm{ft} / \mathrm{yr}$ from irrigation of lawns, 30-90 acre-ft/yr from infiltration of precipitation on open land with non-saline soils, and $260 \mathrm{acre}-\mathrm{ft} / \mathrm{yr}$ from septic tanks. Ground-water discharge and outflow estimated for 1995-98 is probably similar to average conditions and totals 11,000 acre-ft/yr, including 5,100 acre-ft/yr of subsurface outflow, 4,300 acre-ft/yr of pumpage, $370 \mathrm{acre}-\mathrm{ft} / \mathrm{yr}$ of base streamflow, and 880 acre-ft/yr of evapotranspiration.

Independent estimates of evapotranspiration and increased ground-water storage during 1995-98 show that estimates of water-budget components are reasonable and probably within 20 percent of their actual values. However, the volumes of water-budget components will change as a result of variations in climate and changes in land and water use. The volume of water imported to and exported from the hydrographic area and the volume of outflow from Eagle Valley may be greatly affected by water-management practices. With increased development and a greater percentage of land becoming impervious or irrigated for lawns and golf courses, natural ground-water discharge by evapotranspiration will continue to decrease and recharge from irrigation will increase, possibly causing the water table to rise to near land surface in the lower parts of Eagle Valley.

The chemical quality of precipitation, streamflow, subsurface inflow from the mountains, and water used for irrigation from municipal supply generally meets Nevada drinking-water standards. However, subsurface inflow from the west side of Eagle Valley commonly exceeds maximum standards for radon- 222 . Treated effluent and septic tanks are the most likely sources of recharge to cause ground-water contamination. Samples of treated effluent from 1987 to 1997 have concentrations of nitrate, arsenic, cadmium, and lead equal to, or greater than, primary maximum drinking water standards; and concentrations of dissolved solids, iron, and manganese equal to, or greater than, secondary maximum standards.

\section{REFERENCES CITED}

Allison, G.B., Gee, G.W., and Tyler, S.W., 1994, A review of vadose-zone techniques for estimating groundwater recharge in arid and semiarid regions: Soil Science Society of America Journal, v. 58, p. 63-72.

Allison, G.B., and Hughes, M.W., 1978, The use of environmental chloride and tritium to estimate total recharge an unconfined aquifer: Australian Journal of Soil Research, v. 16, p. 181-195.

1983, The use of natural tracers as indicators of soilwater movement in a temperate semi-arid region: Journal of Hydrology, v. 60, p. 157-173.

Allison, G.B., Stone, W.J., and Hughes, M.W., 1985, Recharge in karst and dune elements of a semi-arid landscape as indicated by natural isotopes and chloride: Journal of Hydrology, v. 76, p. 1-26.

Arteaga, F.E., 1986, Mathematical model analysis of the Eagle Valley ground-water basin, west-central Nevada: Nevada Division of Water Resources, Bulletin 45, 53 p.

Arteaga, F.E., and Durbin, T.J., 1979, Development of a relation for steady-state pumping rate for Eagle Valley ground-water basin, Nevada: U.S. Geological Survey Open-File Report 79-261, 44 p. 
Bauer, D.J., Foster, B.J., Joyner, J.D., and Swanson, R.A., 1996, Water-resources data, Nevada, water year 1995: U.S. Geological Survey Water-Data Report NV-95-1, $734 \mathrm{p}$.

Berger, D.L., Ross, W.C., Thodal, C.E., and Robledo, A.R., 1997, Hydrogeology and simulated effects of urban development on water resources of Spanish Springs Valley, Washoe County, west-central Nevada: U.S. Geological Survey Water-Resources Investigations Report 96-4297, 44 p.

Bonner, L.J., Elliot, P.E., Etchemendy, L.P., and Swartwood, J.R., 1998, Water-resources data, Nevada, water year 1997: U.S. Geological Survey Water-Data Report NV97-1, $636 \mathrm{p}$.

Bostic, R.E., Kane, R.L., Kipfer, K.M., and Johnson, A.W., 1997, Water-resources data, Nevada, water year 1996: U.S. Geological Survey Water-Data Report NV-96-1, $611 \mathrm{p}$.

Candland, D.M., 1979, Soil survey of Carson City area, Nevada: U.S. Soil Conservation Service, 169 p.

Cardinalli, J.L., Roach, L.M., Rush, F.E., and Vasey, B.J., comps., 1968, State of Nevada hydrographic areas:

Nevada Division of Water Resources map, scale $1: 500,000$.

Clary, S.L., McClary, D.R., Whitney, Rita, and Reeves, D.D., 1995, Water-resources data, Nevada, water year 1994: U.S. Geological Survey Water-Data Report NV94-1, $768 \mathrm{p}$.

Dettinger, M.D., 1989, Reconnaissance estimates of natural recharge to desert basins in Nevada, U.S.A., by using chloride-balance calculations: Journal of Hydrology, v. 106 , no. $1 / 2$, p. $55-78$.

Dillon, Matt, 1995, Eagle Valley ground-water inventory, pumpage report, water year 1994: Nevada Division of Water Resources Report, 26 p.

Eakin, T.E., Maxey, G.B., Robinson, T.W., Fredricks, J.C., and Loeltz, O.J., 1951, Contributions to the hydrology of eastern Nevada: Nevada State Engineer, Water Resources Bulletin 12, $171 \mathrm{p}$.

Freeze, F.A., and Cherry, J.A., 1979, Groundwater: Englewood Cliffs, N.J., Prentice-Hall, 604 p.

Healy, R.W., and Ronan, A.D., 1996, Documentation of computer program VS2DH for simulation of energy transport in variably saturated porous media-Modification of the U.S. Geological Survey's computer program VS2DT: U.S. Geological Survey WaterResources Investigations Report 96-4230, 36 p.

Heath, R.C., 1989, Basic ground-water hydrology: U.S. Geological Survey Water-Supply Paper 2220, 84 p.

Johnson, K.L., Ball, G.W., Jr., and Harrigan, W.A., 1996, Carson City well completion report amendment, Silver Oak, Speedway, Well 11 redrill sites: Carson City Comprehensive Water Program.
Koterba, M.T., Wilde, F.D., and Lapham, W.W., 1995 Ground-water data-collection protocols and procedures for the National Water Quality Assessment ProgramCollection and documentation of water-quality samples and related data: U.S. Geological Survey Open-File Report 95-399, 113 p.

Laird, L.B., Taylor, H.E., and Lombard, R.E., 1986, Data on snow chemistry of the Cascade-Sierra Nevada Mountains: U.S. Geological Survey Open-File Report 86-61, $25 \mathrm{p}$.

Lawrence, S.J., 1996, Nitrate and ammonia in shallow ground water, Carson City urban area, Nevada, 1989: U.S. Geological Survey Water-Resources Investigations Report 96-4224, 53 p.

Loeltz, O.J., Phoenix, D.A., and Robinson, T.W., 1949, Ground water in Paradise Valley, Humboldt County, Nevada: Nevada State Engineer, Water Resources Bulletin 10,61 p.

Maurer, D.K., 1997, Hydrology and ground-water budgets of the Dayton Valley Hydrographic Area, west-central Nevada: U.S. Geological Survey Water-Resources Investigations Report 97-4123, 89 p.

Maurer, D.K., and Berger, D.L., 1997, Subsurface flow and water yield from watersheds tributary to Eagle Valley Hydrographic Area, west-central Nevada: U.S. Geological Survey Water-Resources Investigations Report 97 4191, $56 \mathrm{p}$.

Maurer, D.K., Berger, D.L., and Prudic, D.E., 1996, Subsurface flow to Eagle Valley from Vicee, Ash, and Kings Canyons, Carson City, Nevada, estimated from Darcy's Law and the chloride-balance method: U.S. Geological Survey Water-Resources Investigations Report 964088, 74 p.

Maurer, D.K., and Fischer, J.M., 1988, Recharge to the Eagle Valley ground-water basin by streamflow in Vicee Canyon, west-central Nevada: U.S. Geological Survey Water-Resources Investigations Report 88-4158, 66 p.

McCord, J.T., Gotway, C.A., and Conrad, S.H., 1997, Impact of geologic heterogeneity on recharge estimation using environmental tracers-Numerical modeling investigation: Water Resources Research, v. 33, no. 6, p. 12291240.

Moore, D.O, 1968, Estimating mean runoff in ungaged semiarid areas: Nevada Department of Conservation and Natural Resources, Water Resources Bulletin 36, 11 p.

Moore, J.G., 1969, Geology and mineral deposits of Lyon, Douglas, and Ormsby Counties, Nevada: Nevada Bureau of Mines Bulletin 75, $45 \mathrm{p}$.

National Climatic Center, 1961-98, Climatological data, annual summary, Nevada, 1960-97: Asheville, N.C., U.S. National Oceanic and Atmospheric Administration, v. 75-v. 112, no. 13 (published annually). 
Nevada Administrative Code, 1992, Public water systemsQuality, December 1980: Nevada Bureau of Health Protection Services, chap. 445, amended March 22, 1989, December 3, 1990, October 14, 1992, 15 p.

Nichols, W.D., 1994, Groundwater discharge by phreatophyte shrubs in the Great Basin as related to depth to groundwater: Water Resources Research v. 30, no. 12, p. 3265-3274.

Nightingale, H.I., and McCormick, R.L., 1985, Chemical quality of perched septic tank effluent for plant use and recharge: Journal Water Pollution Control Federation, v. 57 , no. 9 , p. $916-920$.

Owenby, J.R., and Ezell, D.S., 1992, Monthly station normals of temperature, precipitation, and heating and cooling degree days 1961-1990, Nevada: National Climatic Data Center, Climatography of the United States, no. $81,20 \mathrm{p}$.

Pease, R.C., 1980, Geologic map, Genoa quadrangle: Nevada Bureau of Mines and Geology, Urban Map Series, Genoa Folio, Map 1Cg, scale 1:24,000.

Phillips, F.M., 1994, Environmental tracers for water movement in desert soils of the American Southwest: Soil Science Society of America Journal, v. 58, p. 15-24.

Preissler, A.M., Roach, G.A., Thomas, K.A., and Wilson, J.W., 1999, Water-resources data, Nevada, water year 1998: U.S. Geological Survey Water-Data Report NV98-1, 598 p.

Pritt, J.W., and Raese, J.W., 1995, Quality assurance/quality control manual-National Water Quality Laboratory: U.S. Geological Survey Open-File Report 95-443, 35 p.

Prudic, D.E., 1994, Estimates of percolation rates and ages of water in unsaturated sediments at two Mojave Desert sites, California-Nevada: U.S. Geological Survey Water-Resources Investigations Report 94-4160, 19 p.

Prych, E.A., 1998, Using chloride and chlorine-36 as soilwater tracers to estimate deep percolation at selected locations on the U.S. Department of Energy Hanford Site, Washington: U.S. Geological Survey WaterSupply Paper 2481, 67 p.

Rantz, S.E., comp., 1982, Measurement and computation of streamflow, volumes 1 and 2: U.S. Geological Survey Water-Supply Paper 2175, 631 p.

Riggs, H.C., 1969, Mean streamflow from discharge measurements: Bulletin of the International Association of Scientific Hydrology, v. 14, no. 4, p. 95-110.
Robinson, T.W., 1970, Evapotranspiration by woody phreatophytes in the Humboldt River Valley near Winnemucca, Nevada: U.S. Geological Survey Professional Paper 491-D, 41 p.

Rush, F.E., 1968, Index of hydrographic areas in Nevada: Nevada Division of Water Resources, Information Report 6, 38 p.

Scanlon, B.R., 1991, Evaluation of moisture flux from chloride data in desert soils: Journal of Hydrology, v. 128 , p. $137-156$.

Shelton, L.R., 1994, Field guide for collecting and processing stream-water samples for the National WaterQuality Assessment program: U.S. Geological Survey Open-File Report 94-455, 42 p.

Szecsody, J.E., Jacobson, R.L., and Campana, M.E., 1983, Environmental isotopic and hydrogeochemical investigation of recharge and subsurface flow in Eagle Valley, Nevada: University of Nevada, Desert Research Institute Publication 42037, 120 p.

Trexler, D.T., Koenig, B.A., Flynn, Thomas, and Bruce, J.L., 1980, Assessment of the geothermal resources of Carson-Eagle Valleys and Big Smoky Valley, Nevada-First annual report: Nevada Bureau of Mines and Geology report DOE/NV/10039-2, 162 p.

U.S. District Court, Nevada, 1980, The United States of America v. Alpine Land and Reservoir Co., et. al., Findings of fact, conclusions of law, tabulation and administrative provisions: Final Decree, Civil No. D-183 BRT, $18 \mathrm{p}$.

U.S. Geological Survey, 1988-99, Water resources data, Nevada, water years 1987-98: U.S. Geological Survey Water-Data Reports NV-87-1 to NV-99-1 (published annually).

Welch, A.H., Lawrence, S.J., Lico, M.S., Thomas, J.M., and Schaefer, D.H., 1997, Ground-water quality assessment of the Carson River Basin, Nevada and CaliforniaResults of investigations, 1987-91: U.S. Geological Survey Water-Supply Paper 2356-A, 93 p.

Wood, W.W., 1999, Use and misuse of the chloride-mass balance method in estimating ground water recharge: Ground Water, v. 37, no. 1, p. 2-3.

Worts, G.F., Jr., and Malmberg, G.T., 1966, Hydrologic appraisal of Eagle Valley, Ormsby County, Nevada: Nevada Department of Conservation and Natural Resources, Water Resources - Reconnaissance Report $39,55 \mathrm{p}$. 
Since 1879 , the U.S. Geological Survey has been providing maps, reports, and information to help others who manage, develop, and protect our Nation's water, energy, mineral, land, and biological resources. We help find natural resources, and we supply scientific understanding needed to help minimize or mitigate the effects of natural hazards and the environmental damage caused by human activities. The results of our efforts touch the daily lives of almost everyone.

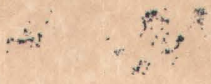

